\title{
ECONOMIC ANALYSIS OF NETWORK EFFECTS AND INTELLECTUAL PROPERTY
}

\author{
Peter S. Menelt
}

\begin{abstract}
The information revolution has brought demand-side effects to the fore of economic activity, business strategy, and intellectual property jurisprudence and policy. Intellectual property doctrines play a central role in harnessing network effects, promoting innovation to overcome excess inertia, and balancing consumer welfare, competition, and innovation. This Article surveys and integrates the economic, business strategy, and legal literatures relating to network effects and intellectual property. Part I introduces the topic of network effects and provides an overview of the Article. Part II describes the functioning of network markets. Part III examines the interplay of business strategy, contract, standard setting organizations, intellectual property, and competition policy. Part IV presents three principles for tailoring intellectual property regimes and competition policy to network technologies. Part V traces the evolution of intellectual property protection for network features of systems and platforms. Part VI discusses the interplay of intellectual property protection and competition policy. Part VII assesses the extent to which intellectual property protection and competition policy align with the normative design principles. Part VIII identifies promising areas for future research.
\end{abstract}

DOI: https://doi.org/10.15779/Z381V5BD7T

(C) 2019 Peter S. Menell.

$\dagger$ Koret Professor of Law and Director, Berkeley Center for Law \& Technology, University of California at Berkeley School of Law. Thanks to participants at the 2015 Economics of Intellectual Property Research Handbook Conference, the 2017 Intellectual Property Scholars Conference, and especially Michael Carrier for their comments on this project. I am grateful to Alex Barata, Concord Cheung, Louise Decoppet, Amit Elazari, Andrea Hall, Megan McKnelly, Reid Whitaker, and Samantha Vega for research assistance. 


\section{TABLE OF CONTENTS}

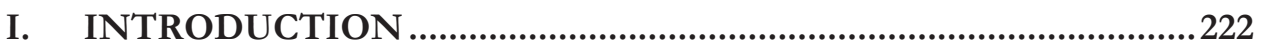

II. FUNCTIONING OF NETWORK MARKETS ................................2225

III. INTERPLAY OF BUSINESS STRATEGY, CONTRACT, STANDARD SETTING, INTELLECTUAL PROPERTY, AND COMPETITION POLICY .

IV. RAMIFICATIONS FOR INTELLECTUAL PROPERTY AND

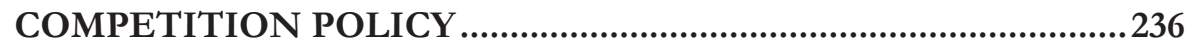

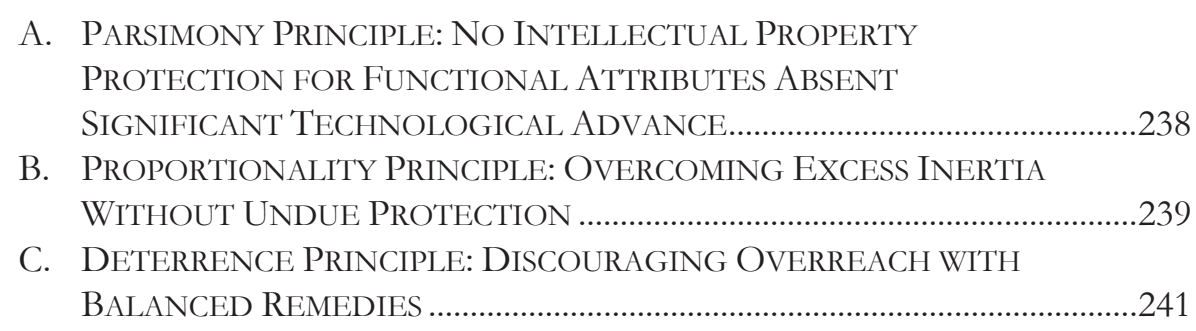

V. INTELLECTUAL PROPERTY PROTECTION FOR

NETWORK FEATURES ...............................................................243

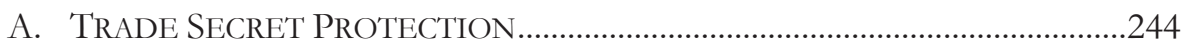

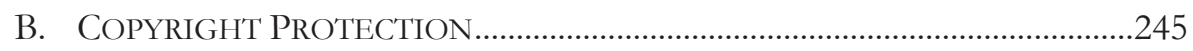

1. Software Copyright Legislation: The Copyright Act of 1976, the

CONTU Report, and the 1980 Amendments .............................................246

2. Software Copyright Jurisprudence: The First W ave......................................248

a) Unprotectability of Functional and Network Features..............249

b) Permissibility of Reverse Engineering .........................................259

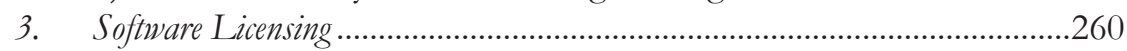

a) The Free Software Movement (General Public License) .........261

b) The Open Software Movement (Permissive Licenses)..............263

c) Dedication to the Public Domain ................................................264

d) Federal Preemption of Contractual Restrictions ........................264

4. Interoperability Exception to the DMCA's Anti-Circumvention

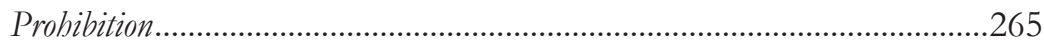

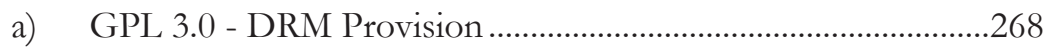

5. Software Copyright Jurisprudence: The Oracle v. Google Litigation..................268

6. Standards and Codes ..............................................................................273

C. Trademark Protection, Unfair Competition Law, AND

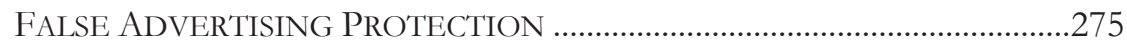

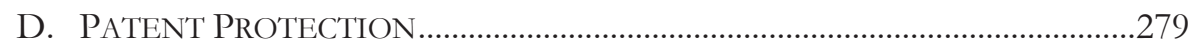

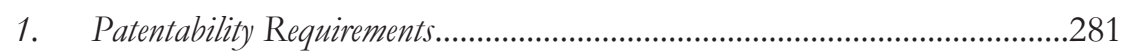

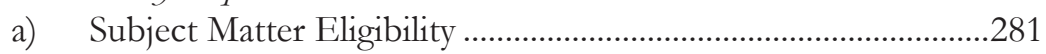

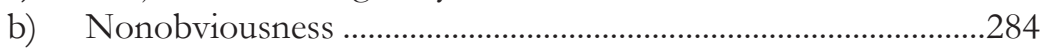

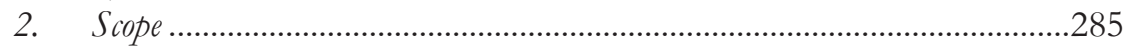




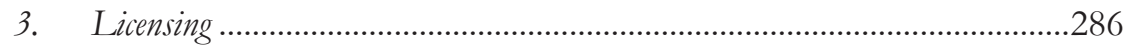

a) Standard-Setting and FRAND Commitments ...........................286

b) Insurance Pools and License on Transfer (LOT)

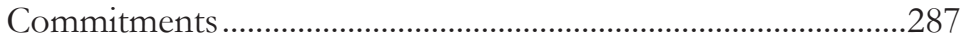

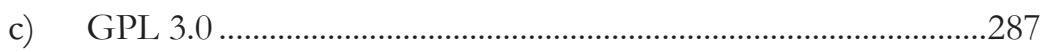

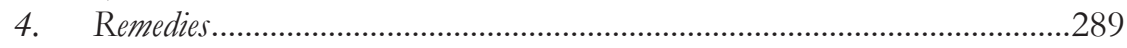

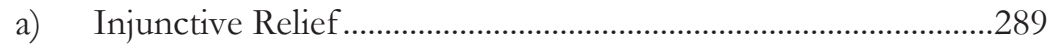

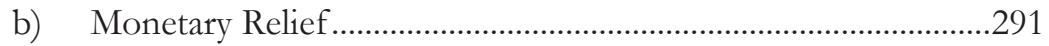

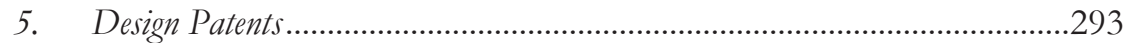

VI. INTERPLAY OF INTELLECTUAL PROPERTY PROTECTION AND COMPETITION POLICY IN NETWORK INDUSTRIES........................................................2295

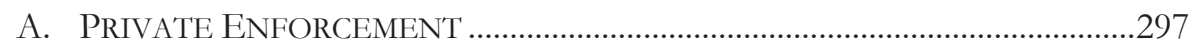

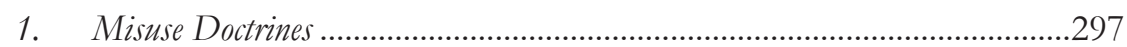

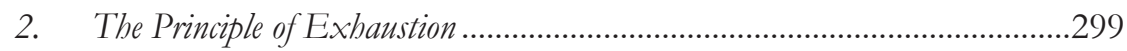

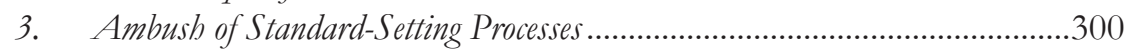

4. Breach of Contract for Failure to License SEPs on FRAND Terms.............302

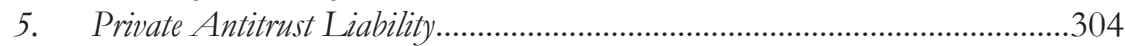

a) Refusals to License Patented Technologies and

Copyright-Protected Works ...........................................................304

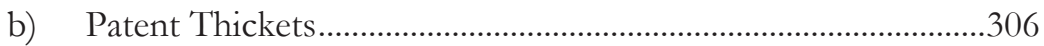

c) Improper Leveraging of Market Power .......................................307

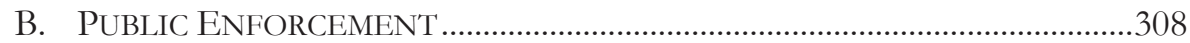

1. Intellectual Property Licensing Guidelines....................................................309

2. Significant Network Market Enforcement Actions .........................................312

VII. ASSESSMENT OF INTELLECTUAL PROPERTY PROTECTION AND COMPETITION POLICY FOR

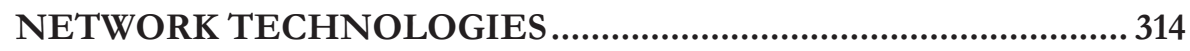

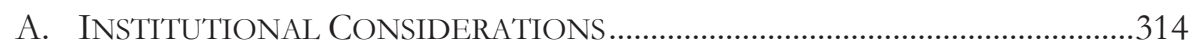

B. Measuring Progress Based on the Normative Principles .........315

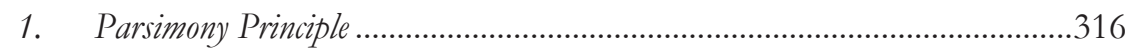

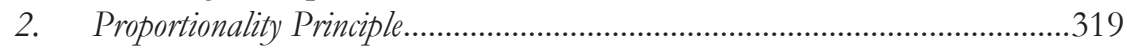

3. Deterrence Principle ……………………………….....................................321

VIII. FUTURE RESEARCH DIRECTIONS ..........................................322 


\section{INTRODUCTION}

The economics of intellectual property begins with the classic appropriability problem: In a competitive economy, imitators can enter markets for information goods after inventors and authors have incurred research and development $(\mathrm{R} \& \mathrm{D})$ costs and sell the innovative or creative product at the cost of reproduction. Without means for appropriating an adequate return on investment in $\mathrm{R} \& \mathrm{D}$, the market will under-produce technological advances and creative expression. ${ }^{1}$

The provision of intellectual property protection for technological advances and creative expression affords inventors and authors a mechanism to recoup their investments, although not without imposing the deadweight loss of monopoly exploitation and potentially interfering with cumulative creativity. ${ }^{2}$ Conventional analysis of intellectual property seeks to optimize the duration and scope of intellectual property rights in order to balance these tradeoffs. ${ }^{3}$ This framework applies to goods and services for which consumer demand is independent-i.e., where one consumer's utility from consuming a good or service does not depend on choices of other consumers.

Yet consumer demand for information goods and services can be interdependent, especially in the digital age. The consumers' valuation of systems technologies_ _ such as telecommunication networks (e.g., telephone networks, cable systems, satellite systems, and Internet protocols), interconnected devices (e.g., mobile phones, operating systems and application programs, printers and replacement cartridges, and audio-video devices and media), databases (e.g., Internet searches), and electric charging stations (e.g., Tesla superchargers) —often depends upon other consumers' choices. For example, a smartphone platform with many adopters will attract more app developers, thereby increasing the functionality and value of that platform for consumers, developers of complementary goods (e.g., apps), and the platform sponsor.

1. See Peter S. Menell \& Suzanne Scotchmer, Intellectual Property Law, in 2 HANDBOOK OF LAW AND ECONOMics 1473, 1478-79, 1499-500 (A. Mitchell Polinsky \& Steven Shavell eds., 2007).

2. See Peter S. Menell, Mark A. Lemley \& Robert P. Merges, Intellectual Property in the New Technological Age: 2018, Vol I: Perspectives, Trade SECRETS, AND PATENTS 168 (2018).

3. See Nancy T. Gallini, Patent Policy and Costly Imitation, 23 RAND J. ECON. 52, 62-63 (1992) (analyzing "optimal patent design when costly imitation displaces a patentee's output as the length of patent protection increases"); see generally WILLIAM D. NORDHAUS, InVENTION, GrowTH, AND Welfare: A THEORETICAL TREATMENT OF TECHNOLOGiCAL ChANGe (1969). 
Platforms function like a common language. Devices that "speak" a common language (such as a programming language, application program interface (API) specification, or a set of graphical user icons) can communicate with other devices and humans familiar with that language. Innovators can more easily design peripheral equipment that expands the functionality of existing devices. Over time, users internalize how a computer language or application program represents functions, often memorizing the most commonly used series of keystrokes or developing macros customized to perform their most common tasks. These human capital investments commit users to particular languages and platforms and encourage employers to adopt systems that are widely known by prospective employees so as to recruit promising candidates and reduce training costs. ${ }^{4}$ Thus, it is common for people seeking jobs in programming, accounting, and design fields to list those computer languages and application programs that they have mastered on their resumes. Network externalities arise from the enhanced labor mobility and reduced training costs produced by shared, or at least compatible, computer systems across different work environments. When people in different places can communicate more efficiently through compatible file formats, network externalities result.

The value of networks grows disproportionately with their adoption bases. Such positive feedback dynamics drive a growing number of markets in the information economy, ${ }^{5}$ from computer operating systems to mobile phones, printers (and ink cartridges), video game consoles, Internet search engines (such as Google), Internet commerce (such as eBay and Amazon), social networks (such as Facebook, LinkedIn, and Tinder), cloud computing, the Internet of Things, and shared economy platforms (such as Airbnb and Uber).

Advances in digital and network technologies have dramatically reshaped the competitive and innovative landscape. As a consultant for the Internet dating industry has remarked, "[i]t's never been cheaper to start a dating site and never been more expensive to grow one." "Dating apps usually start by offering free services to new users, seeking to build a viral bandwagon. If they gain traction through innovative features or marketing, they then face the daunting task of monetizing the network, typically through advertising or

4. See Neil Gandal, Hedonic Price Indexes for Spreadsheets and an Empirical Test for Network Externalities, 25 RAND J. ECON. 160, 168-69 (1994).

5. See generally CARL SHAPIRO \& HAL R. VARIAN, INFORMATION RULES: A STRATEGIC Guide TO THE NETWORK ECONOMY 103-226 (1999).

6. Alina Tugend, For Online Dating Sites, a Bumpy Road to Love, N.Y. Times (Dec. 24, 2016), https://www.nytimes.com/2016/12/24/business/online-dating-sites-jdatechristianmingle.html [https://perma.cc/3AME-4DKS]. 
membership fees. Monetization, however, can reverse the positive feedback effects, thereby reducing the network's size, unraveling the network's benefits, and jeopardizing the platform's sustainability. Finding the right balance between viral growth and monetization is the principal challenge of a growing range of enterprises in the Internet Age.

The interdependence of consumer demand has important ramifications for the design of intellectual property and competition policy. In a static economic model (i.e., one without innovation), consumers benefit from robust competition within product standards. Open access to product standards encourages realization of network externalities. Although bandwagon effects can enhance consumer welfare in a static context, they can also make it more difficult for developers of improved platforms to enter the market. Consumers and suppliers of complementary products can face significant switching costs in migrating from one platform to another. For example, once businesses have invested heavily in developing programs to run on a software platform (e.g., macros for the Lotus 1-2-3 spreadsheet), it becomes much more difficult for a competitor offering an enhanced spreadsheet (e.g., Borland Quattro Pro) to enter the market unless they can provide a low-cost migration path. Facebook's widespread success and user investment made it difficult for even Google to build a sustainable competing social network. Orkut, Google Buzz, Google Friend Connect, and Google+ have failed or languished.

The technical standards governing access to platforms, commonly referred to as application program interfaces (APIs) in the software industry, play a critical role in consumer and programmer adoption decisions, market entry, and competition. Those who control a widely-adopted platform can obstruct new innovative platforms and complementary products and services (such as refilling and repair). Familiarity with the user interface and features, connections to other network adopters (such as Facebook friends), and investments in complementary assets (such as macros that run on the platform) can keep consumers on an otherwise inferior platform. The human capital investment in learning an API can lock programmers into a platform, and sunk costs in manufacturing facilities, fabrication designs, and contracts with suppliers and customers can lock manufacturers into design choices.

At the same time, the ability to secure an innovative platform can be vital to investing in the R\&D needed to advance systems technologies. Without the prospect of earning a significant return on research, development, and marketing of a new platform, investors have little incentive to take on the risk of investing the substantial resources necessary to challenge an entrenched platform. Therefore, the availability, scope, and remedies for intellectual property protection for network features of systems technologies and platforms (e.g., interface specifications) provide a key strategic asset for 
controlling network markets and a critical mechanism for promoting advances in network technologies.

Demand-side or network effects, therefore, complicate the design of an optimal intellectual property regime. Control of interface specifications and other network features of computer technologies through intellectual property protection has become the key to market dominance in a growing number of important Information Age markets. Nearly all of the major software copyright disputes, as well as a key exception to the Digital Millennium Copyright Act's (DMCA) anti-circumvention provisions, have revolved around the protectability of interface specifications. Patent protection for network technologies has also become a critical battleground with some disputes centered on licensing network technologies through standard setting organizations. Trade secrecy, trademark protection, and contract law are also important tools for regulating competition in network markets.

This Article explores the critical role of intellectual property in network markets as well as the ramifications of network effects for the design of intellectual property regimes. Part II describes the functioning of network markets. Part III examines the interplay of business strategy, contract, standard setting organizations, intellectual property, and competition policy with regard to network coordination. Part IV presents three principles for tailoring intellectual property regimes and competition policy for network technologies. Part V traces the evolution of intellectual property protection for network features of systems and platforms. Part VI discusses the interplay of intellectual property protection and competition policy. Part VII assesses the extent to which intellectual property protection and competition policy align with normative design principles. Part VIII identifies promising areas for future research.

\section{FUNCTIONING OF NETWORK MARKETS}

In many market settings, consumers' utility functions are independent. Take, for example, the market for ice cream. My enjoyment of a particular flavor (e.g., hazelnut chocolate chip), style (e.g., gelato), or brand (e.g., Talenti) does not depend significantly on the utility that other consumers derive from the purchase and consumption of ice cream. It is possible that greater popularity of a flavor, style, or brand makes that combination more widely available or lowers the price due to economies of scale on the production side, but competition usually ensures efficient allocation of resources in these

circumstances. The effects are more likely pecuniary, which work through the 
market and only affect the distribution of value, than technological, which affects the economic efficiency of the economy. ${ }^{7}$

By contrast, some market equilibria depend critically on the number of consumers that have joined or are likely to join a particular platform. Take, for example, a social network like Facebook. A new entrant to this market, say Google+, might offer enhanced functionality. But if most of my social network is already on Facebook and I cannot easily bridge the two networks, then I am far less likely to switch.

Network effects have long been central to human civilization and market economies. Languages, measurement systems (metric versus imperial), electrical equipment standards (alternating current versus direct current; computer networking protocols), driving conventions (left side versus right side), and railroad gauges (the width between and across rails) are notable examples where demand-side coordination greatly influences consumer welfare, economic efficiency, and social discourse. Standardized railroad gauge, for example, supported far-reaching railroad networks, promoted competition in locomotive and railcar markets, and enabled interconnected rail services. ${ }^{8}$ Part III focuses on how such coordination or standardization occurs through business strategy, technological innovation, intellectual property law, industry and consumer coordination, and government policies (including antitrust law).

The economic and social value of network effects can be substantial. According to Metcalfe's Law_attributed to Robert Metcalfe, co-inventor of the Ethernet, a local computer network platform that foreshadowed and ushered in the Internet - the value of a telecommunications network is proportional to the square $\left(\mathrm{n}^{2}\right)$ of the number of devices (or nodes (n)) in the system. This economic "law" reflects the potential number of contacts within a network and assumes that they are each of equal value. Even though this theoretical maximum is unlikely to be obtained in the real world, ${ }^{9}$ the powerful growth potential of network systems drives much of the information economy. The net value, of course, also depends on the cost per user. In many telecommunications and computer applications, such costs are low and have declined over time because of Moore's Law-Intel co-founder Gordon Moore's audacious, yet remarkably accurate, prediction that the number of

7. See Stan J. Liebowitz \& Stephen E. Margolis, Network Externality: An Uncommon Tragedy, 8 J. ECON. PERSP. 133, 137-39 (1994).

8. See Douglas J. Puffert, The Standardization of Track Gange on North American Railways, 1830-1890, 60 J. ECON. HisT. 933, 944-47 (2000).

9. See Bob Briscoe, Andrew Odlyzko \& Benjamin Tilly, Metcalfe's Law Is Wrong, IEEE SPECTRUM (July 1, 2006), https://spectrum.ieee.org/computing/networks/metcalfes-law-iswrong [https://perma.cc/ET4W-D7YV]. 
transistors on an integrated circuit would double every two years (later reduced to eighteen months). ${ }^{10}$

Both real and virtual networks can produce these effects. ${ }^{11}$ Real networks entail physical connectivity enabling a user to interact or communicate directly with others. They include transportation systems (such as railroad gauges), telecommunication systems (such as a telephone or broadcast network), and media systems (such as data storage devices). By contrast, virtual networks operate through the evolution of markets for complementary products. The supply of complementary goods typically drives these markets. For example, by enabling programmers to develop apps for the iOS platform, Apple promotes a virtual network surrounding its iPhone and other computer devices. The availability of apps on iOS drives demand for iOS devices, which in turn attracts app developers. More apps generate a wide range of functionality, thereby spurring increased demand for iPhones. Other examples of virtual networks include application programs that enable users to share data files with other programs and users, ATM cards and automatic teller machines, credit cards, and the merchants who accept them, and next generation payment systems such as Apple Pay and Square. The defining feature of virtual networks is that the demand for the product depends significantly on the availability of complementary goods and services.

The magnitude of network effects depends on several considerations: interdependencies of consumer utility functions, range of complementary products or services, availability of alternative platforms, switching costs, business strategies, and legal limits on leveraging network markets (such as intellectual property protection and competition policy). In some cases, physical limitations govern network access-e.g., where a device must physically or digitally interoperate with other devices. In others, the network is not physically constrained, but instead driven by consumer familiarity or ease of use.

The design determinants of a network market-interoperability or compatibility standards - are shaped by the type and degree of ownership, sponsorship, and governance of network access. Some network standards are

10. See Gordon E. Moore, Cramming More Components onto Integrated Circuits, 38 ELECTRONICS 114 (1965) (predicting that the number of transistors in an integrated circuit would double approximately every two years); see also Jonathan Borwein \& David H. Bailey, Moore's Law Is 50 Years Old but Will It Continue?, Conversation (July 20, 2015), http://theconversation.com/moores-law-is-50-years-old-but-will-it-continue-44511 [https://perma.cc/8PFQ-Q84J].

11. See SHAPIRO \& VARIAN, supra note 5, at 183; see also Michael Katz \& Carl Shapiro, Network Externalities, Competition, and Compatibility, 75 AM. ECON. REV. 424, 424-25 (1985). 
established or authorized by a government, international organization, or formal standard-setting organization (SSO). These are sometimes referred to as de jure standards as they have official backing and can be enforced by law. Such enforcement can limit or afford access to standards. Individual companies or consortiums sponsor many important network standards. These are sometimes referred to as de facto standards, although they might be backed by patent, copyright, trademark, or false advertising law.

An important distinction in network markets relates to whether a standard is "free," open, closed (i.e., proprietary), or somewhere in the middle. ${ }^{12}$ The Free Software Movement allows other users to run, study, share, copy, and modify the software so long as these users permit use of any derivative works on the same terms. "Open source" software typically connotes that the software or interface is freely available to any market participant, but there might or might not be restrictions on the availability of complementary goods embodying the standard. A closed or proprietary standard is one in which a sponsoring enterprise or organization regulates access, typically through licensing of intellectual property rights.

The distinction between open and closed standards can be ambiguous. For example, many SSOs require that participating enterprises license standardessential patents on fair, reasonable, and non-discriminatory (FRAND) terms. ${ }^{13}$ Substantial uncertainty arises because patent owners rarely fully specified in advance which patents are "standard-essential" or the license terms on which they are available. ${ }^{14}$ On the other hand, "free" software licensed pursuant to the General Public License (GPL) requires users to make available any software incorporating the licensed code under the same "share and share alike" restriction. ${ }^{15}$

The controversy over the Java API platform illustrates the complexity that can arise surrounding intermediate-i.e., partially open-platforms. ${ }^{16}$ Sun Microsystems released the Java programming language without restriction in

12. See Heather J. Meeker, Open (Source) For Business: A Practical Guide to Open Source Software Licensing 31-47 (2015) (describing the economic and technological forces that shape standards); see also Joel West, The Economic Realities of Open Standards: Black, White, and Many Shades of Gray, in STANDARDS AND PUBLIC POLICY 87 (Shane Greenstein \& Victor Stango eds., 2007).

13. See generally Michael Mattioli, Patent Pool Outsiders, 33 BeRKELEY TECH. L.J. 233 (2018).

14. See Jorge L. Contreras \& Richard J. Gilbert, A Unified Framework for RAND and Other Reasonable Royalties, 30 BERKELEY TECH. L.J. 1451 (2015).

15. See Brian W. Carver, Share and Share Alike: Understanding and Enforcing Open Source and Free Software Licenses, 20 BERKELEY TECH. L.J. 443, 455 (2005).

16. See Peter S. Menell, Rise of the API Copyright Dead: An Updated Epitaph for Copyright Protection of Network and Functional Features of Computer Software, 31 HARV. J.L. \& TECH. 305, 346414 (2018); see also Mark A. Lemley \& David McGowan, Could Java Change Everything? The Competitive Propriety of a Proprietary Standard, 43 ANTITRUST BuLl. 715, 756-72 (1998). 
part to prevent Microsoft from leveraging its Windows desktop computer operating system monopoly into dominance of website functionality. Sun's Java strategy promoted the "Write Once, Run Anywhere" (WORA) principle: the notion that any browser can execute Java applets (small application programs, such as those used for animated web pages) on any operating system - including on Microsoft Windows, Unix, macOS, and Linux.

Over time, Sun developed pre-written API packages to facilitate Java programming. Sun developed the Java Community Process (JCP), a quasipublic formalized administrative process, for developing technical specifications for Java technology and extensions. Sun used the JCP and licensing of the Java trademark to promote collaboration and commitment to the WORA principle. When Google sought to use some, but not all, of the Java APIs to develop the Android platform and licensed Android using a less restrictive licensing regime (i.e., not requiring that derivative works be shared on a "free" basis), Sun and Oracle (which acquired Sun Microsystems in 2010) objected, resulting in one of the costliest intellectual property battles in recent memory. ${ }^{17}$

Network effects arise whenever the value that consumers place on a product or service depends upon the number of other consumers or programmers purchasing that product or using that service. As the number of adopters (or the installed base) of a platform grows, the benefits of being part of that platform increase. For example, consumers generally prefer telephone networks or protocols offering the largest user bases.

Like economies of scale (declining unit costs with increased production) on the supply-side of a market, the value of a network generally increases with widespread adoption. The availability of better application programs to run on an operating system platform will lead more consumers to prefer that operating system, which in turn will spur a greater quantity and quality of application programs for that operating system. Whereas economies of scale typically fall off at some point due to technical or organizational limits, positive feedback on the demand side generally continues to increase with the size of the installed base. For this reason, a single standard or a very small number of standards are likely to predominate in markets with strong network effects, as reflected in Microsoft's dominance in the market for microcomputer operating systems, Google's dominance among Internet search engines, and Facebook's dominance as a social network.

17. See Menell, supra note 16. Section V.B.5 explores this litigation. 
The high value that consumers place upon standardization, however, can make it particularly difficult for improved products to break into the market. Such bandwagon effects can stifle development and diffusion of improved technology platforms. ${ }^{18}$

\section{INTERPLAY OF BUSINESS STRATEGY, CONTRACT, STANDARD SET'TING, INTELLECTUAL PROPERTY, AND COMPETITION POLICY}

The dynamics of network technologies produce a particularly complex strategic playing field. Firms typically choose among three strategies when competing in network markets: (1) market dominance through establishing and controlling a new proprietary standard; (2) adopting an existing standard either through imitation (where it is legally permissible) or licensing; or (3) working with other firms in the industry-either informally, contractually, through formal industry organizations, or through governmental standardization bodies - to develop an open or quasi-open standard. ${ }^{19}$

Among the strategies firms use to establish their product or service as the de facto industry standard are: massive advertising campaigns; penetration pricing (pricing products or services below cost or giving them away in order to hasten adoption by consumers); issuing impressive product preannouncements to entice consumers and discourage competitors; providing adopters with various forms of insurance (such as short-term leases or pricing arrangements that tie the price of the system to the number of adopters); licensing of the product in order to grow the network more rapidly (and to create competition in the expansion of the network); and vertical integration and strategic investments into markets for complementary products to assure consumers that valuable application programs will be available. $^{20}$

18. See Joseph Farrell \& Garth Saloner, Standardization, Compatibility, and Innovation, 16 RAND J. ECON. 70, 75-79 (1985).

19. See Joseph Farrell \& Garth Saloner, Coordination Through Committees and Markets, 19 RAND J. ECON. 235 (1988); Stanley M. Besen \& Joseph Farrell, Choosing How to Compete: Strategies and Tactics in Standardization, 8 J. ECON. PERSP. 117 (1994); see generally SHAPIRO \& VARIAN, supra note 5, at 184-86; Joseph Farrell \& Timothy Simcoe, Choosing the Rules for Consensus Standardization, 43 RAND J. ECON. 235 (2012).

20. See generally SHAPIRO \& VARIAN, supra note 5; Farrell \& Simcoe, supra note 19; Joseph Farrell \& Paul Klemperer, Coordination and Lock-In: Competition with Switching Costs and Network Effects, in 3 HandBoOK OF Industrial Organization (Mark Armstrong \& Robert H. Porter eds., 2007); Kenneth C. Baseman, Frederick R. Warren-Boulton \& Glenn A. Woroch, Microsoft Plays Hardball: The Use of Exclusionary Pricing and Technical Incompatibility to Maintain Monopoly Power in Markets for Operating System Software, 40 ANTITRUST BuLL. 265, 273-80 (1995) 
Adopting an existing standard enlarges the size of a network comprising both the entrant's product and its rival's — the existing platform's-products. This increases the desirability of the rival's products to consumers, thereby reducing the adopter's market share (although of a larger market) relative to what it would have been had the firm adopted an incompatible product standard. Thus, even though the net social welfare of adopting a rival's standard may exceed the net social welfare of introducing an incompatible standard, the entrant may nonetheless prefer to adopt an incompatible standard because the entrant cannot appropriate all the benefits of compatibility, some of which accrue to past and present purchasers of the rival's products. ${ }^{21}$

Firms often pursue Strategy 2 (adopting an existing standard) and Strategy 3 (collaborating with other firms in establishing a standard) in tandem. Both strategies create a more traditional market setting in which firms compete over price, quality, and services to win market share on a common platform. This achieves greater competition on a particular platform and fosters the realization of network externalities but may impair competition to innovate better platforms. ${ }^{22}$ The market dominance strategy is often riskier but can produce the highest payoff for the winner.

A firm's strategy will depend on a range of factors, including its reputation among consumers for serving the type of network market that it has targeted, its available resources (and access to capital markets) to make the investments in distribution and marketing necessary to persuade consumers that the firm will prevail in the standard battle, the strength of its technology for establishing a standard (although such technology need not be superior to others on the market), and complementary assets within the firm or strong strategic alliances in vertical markets. The firm's strategy will also depend upon the availability of intellectual property protection, contractual means, and technological controls (e.g., encryption technology) for precluding, limiting, or delaying access by competitors to the firm's standard.

(describing Microsoft's monopolistic pricing strategies); Joseph Farrell \& Garth Saloner, Installed Base and Compatibility: Innovation, Product Preannouncements, and Predation, 76 AM. ECON. REV. 940, 940 (1986).

21. See Katz \& Shapiro, supra note 11, at 435 (finding that firms with good reputations or large existing networks might pursue a proprietary strategy even when social welfare is increased by purusing a compatibility statetgy because the firms cannot appropriate the full value (or enough of the value) of the network externalities); see generally Michael L. Katz \& Carl Shapiro, Technology Adoption in the Presence of Network Externalities, 94 J. POL. ECON. 822 (1986).

22. See Michael L. Katz \& Carl Shapiro, Systems Competition and Network Effects, 8 J. ECON. PERSP. 93, 108-10 (1994). 
IBM successfully pursued the market dominance strategy when it entered the microcomputer market in the early 1980s. IBM combined its reputation for serving the mainframe market and technological and marketing capabilities with copyright and trade secrecy protection for its basic instruction operating system (BIOS) chip. IBM's strategic hold on the industry quickly unraveled, however, when competitors successfully reverse engineered the BIOS chip, ${ }^{23}$ making much less expensive, fully compatible IBM clones available on the market by the mid to late 1980s. IBM exited the microcomputer hardware industry soon thereafter.

Microsoft emerged as the winner in the microcomputer industry during this upheaval. Its DOS operating system, on which IBM had previously built its microcomputers, emerged as the de facto standard. Robust competition in microcomputers using DOS and a growing array of application programs (including several Microsoft flagship products such as Word and later Excel) drove adoption of DOS-based computers and fueled Microsoft's dominance. Microsoft skillfully migrated users from DOS to Windows, withstanding Apple's assertion of intellectual property control of the Mac desktop graphical user interface. By the mid-1990s, Microsoft dominated the microcomputer industry through its control of the Windows platform. Apple was a distant second and fading.

The emergence of the Internet in the mid-1990s opened new modes of competition in computer markets. Netscape's Navigator Internet browser and Sun's highly interoperable Java platform threatened Microsoft's dominance in the microcomputer and software marketplace. ${ }^{24}$ Microsoft responded by integrating its browser technology, Internet Explorer, into the Windows operating system and engaging in restrictive licensing agreements with microcomputer manufacturers, thereby reducing the effective price of its browser to zero. Consequently, the market for Netscape's browser evaporated. Microsoft also undermined Java's efforts to establish a universal meta-platform for software application programs by offering a proprietary, non-interoperable version. $^{25}$

Network effects have allowed one or a few firms to dominate many Internet markets, including search (Google), social networks (Facebook),

23. See Russell Moy, A Case Against Software Patents, 17 SANTA Clara Computer \& HigH TECH. L.J. 67, 70-73 (2000) (chronicling reverse engineering of the IBM BIOS); see generally Peter S. Menell, Tailoring Legal Protection for Computer Software, 39 STAN. L. REV. 1329 (1987) (analyzing legal protection for computer software).

24. See Lemley \& McGowan, supra note 16, at 741-42.

25. See Sun Microsystems, Inc. v. Microsoft Corp., 999 F. Supp. 1301, 1305 (N.D. Cal. 1998). 
mobile (iOS, Android), commerce (Amazon, eBay), content streaming (YouTube, Netflix, Spotify), payment systems (PayPal), and sharing networks (Airbnb, Uber). Apple successfully regained prominence in critical digital markets through its mobile and App Store network market strategies.

Formal standardization plays a tremendous role in many electronics and telecommunications markets. ${ }^{26}$ Russell traces electrical standardization through formal standard-setting organizations for more than a century. ${ }^{27}$ These processes have relied on engineers and scientists seeking to promote the best engineering solutions to technical challenges. They form key infrastructure for the electronics and telecommunications industries. Engineers from major technology companies participate in dozens of standard-setting organizations, including many of the leading professional engineering societies, such as the IEEE Standards Association and the Internet Engineering Task Force (IETF). These processes have carried over to semiconductor designs, mobile phones, Internet protocols, and computer devices. A typical laptop computer today embodies more than 250 technical standards. ${ }^{28}$

Intellectual property protection for network technologies can significantly influence the development of standards, follow-on innovation, and market competition. Patents in the information and communication technology fields (semiconductors, computers, and mobile phones) have presented the most salient concerns.

Building on Williamson's classic treatment of economic holdup ${ }^{29}$ whereby asymmetric information, transaction costs, and incomplete contracts create the potential for a contracting party to extract the value of sunk or locked in, relationship-specific investments-Lemley and Shapiro ${ }^{30}$ posit a patent bargaining model in the shadow of strong potential remedies (automatic injunctive relief and large monetary awards) that generates an analogous

26. See Jorge L. Contreras, Technical Standards, Standards-Setting Organizations and Intellectual Property: A Survey of the Literature (with an Emphasis on Empirical Approaches), in 2 RESEARCH Handbooks on the Economics of Intellectual Property Law (Peter S. Menell \& David L. Schwartz eds., 2019); Mark A. Lemley, Intellectual Property Rights and Standard-Setting Organizations, 90 CALIF. L. REV. 1889, 1894-95 (2002).

27. See Andrew L. Russell, Industrial Legislatures: The American System of Standardization, in INTERNATIONAL STANDARDIZATION AS A STRATEGIC TOOL 71, 72-76 (2006).

28. See Contreras, supra note 26 , at 7.

29. See generally Oliver Williamson, The ECONOMic Institutions of CApitalism (1985).

30. See Mark A. Lemley \& Carl Shapiro, Patent Holdup and Royalty Stacking, 85 TEx. L. REV. 1991 (2007). 
inefficient dynamic. Companies that unwittingly sink large investments into infringing products are subject to having such investments extracted through patent infringement litigation. Such extraction can greatly exceed the contribution of the patented technology relative to the best non-infringing alternative. The presence of multiple patents covering a single product - what has been referred to as the patent thicket problem ${ }^{31}$ —exacerbates holdup effects, creating a royalty stacking problem: total patent royalty demands may exceed the contribution of patented technologies to the market demand for the product.

Various scholars have questioned Lemley and Shapiro's assumptions and empirical basis for royalty stacking. ${ }^{32}$ They note that royalty stacking is unlikely to occur with full information and low transaction costs. There is good reason, however, to question optimism about ex-ante bargaining. Ziedonis, for example, finds that firms acquire patents more aggressively when the patents for numerous component technologies of an industry-like the semiconductor industry - are widely distributed. ${ }^{33}$ The proliferation of patent litigation over information and communication technology indicates that intellectual property protection imposes at least some implicit tax on these network industries. Nonetheless, more recent empirical research raises doubts about the severity of royalty stacking. Galetovic and Gupta, for example, find that mobile wireless prices have fallen, quantities have grown, and the industry has become less concentrated over time, indicating that royalty stacking may not be as serious as prior research had claimed. ${ }^{34}$ Barnett surveys the growing

31. See Carl Shapiro, Navigating the Patent Thicket: Cross Licenses, Patent Pools, and Standard Setting, 1 InNOVATION POL'Y \& ECON. 119, 119-22 (2000).

32. See Einer Elhauge, Do Patent Holdup and Royalty Stacking Lead to Systematically Excessive Royalties?, 4 J. COMPETITION L. \& ECON. 535 (2008); J. Gregory Sidak, Holdup, Royalty Stacking, and the Presumption of Injunctive Relieffor Patent Infringement: A Reply to Lemley and Shapiro, 92 MINN. L. REV. 714 (2008); Damien Geradin, Anne Layne-Farrar \& A. Jorge Padilla, The Complements Problem Within Standard Setting: Assessing the Evidence on Royalty Stacking, 14 B.U. J. SCI. \& TECH. L. 144 (2008); Damien Geradin \& Miguel Rato, Can Standard-Setting Lead to Exploitative Abuse? A Dissonant View on Patent Hold-Up, Royalty Stacking and the Meaning of FRAND, 3 EUROPEAN Competition J. 101 (2015); John M. Golden, "Patent Trolls" and Patent Remedies, 85 Tex. L. REV. 2111 (2007). But see Mark A. Lemley \& Carl Shapiro, Reply: Patent Holdup and Royalty Stacking, 85 TEx. L. REV. 2163 (2007).

33. See Rosemarie H. Ziedonis, Don't Fence Me In: Fragmented Markets for Technology and the Patent Acquisition Strategies of Firms, 50 MGMT. SCI. 804, 817-19 (2004).

34. See Alexander Galetovic \& Kirti Gupta, Royalty Stacking and Standard Essential Patents: Theory and Evidence from the World Mobile Wireless Industry 24-25 (Hoover Institution Working Grp. on Intellectual Prop., Innovation \& Prosperity, IP Working Paper Series No. 15012, Mar. 2017). 
literature and concludes that the evidence of royalty stacking is weak. ${ }^{35}$ All would agree, however, that industry coordination through patent pooling and SSOs can alleviate these problems. ${ }^{36}$ Such pools, however, can facilitate collusion, raise barriers to entry, and spark other public policy concerns. ${ }^{37}$

Notwithstanding the widespread use of standard-setting processes and agreements on technical standards, the rules governing access to standards and the licensing of patented technologies are rarely specified in advance. Standard setting organizations (SSOs) exercise caution to avoid violating antitrust laws barring price-fixing. In addition, many companies participating in standardsetting processes do not wish to reveal their patent prosecution strategies or pre-commit to price terms. Thus, most technical SSOs require only that participants disclose their patented technologies and agree to license standardessential patents (SEPs) on FRAND terms. The potential for holdup and royalty stacking remains. ${ }^{38}$

Some sectors of the software industry have alleviated or avoided these risks by committing to open source policies. ${ }^{39}$ Viral forms of open source licensing, such as the GPL, however, can discourage investment in downstream innovation by limiting direct appropriability for technological advances. For this reason, Google chose a more permissive open source license for Android. ${ }^{40}$ This fostered collaboration and rapidly expanded the Android network while encouraging innovation by handset makers and telecommunications companies.

35. See Jonathan M. Barnett, Has the Academy Led Patent Law Astray?, 32 BERKELEY TECH. L.J. 1313,1344-61 (2017).

36. See generally NAT'L RESEARCH COUnCIL OF THE NAT'L ACADS., PATENT Challenges for STANDARD-SetTing in the Global ECONOMY: LeSSONS From Information And Communications Technology (Keith Maskus \& Stephen A. Merrill eds., 2013).

37. See generally Richard J. Gilbert, Antitrust for Patent Pools: A Century of Policy Evolution, 2004 Stan. TECH. L. REV. 3 (2004).

38. See Contreras, supra note 26, at 16-20; see generally FED. TrADE COMM'N, THE Evolving IP Marketplace: Aligning Patent Notice and Remedies with COMPETITION (2011) [hereinafter FTC REPORT]; Lemley \& Shapiro, supra note 30.

39. See Robert P. Merges, A New Dynamism in the Public Domain, 71 U. CHI. L. REv. 183 (2004).

40. See Menell, supra note 16, at 357-72. 


\section{RAMIFICATIONS FOR INTELLECTUAL PROPERTY AND COMPETITION POLICY}

As the preceding analysis suggests, intellectual property protection can play a critical role in network markets. As one software entrepreneur metaphorically explained, creating an API is analogous to building a city:

First you try to persuade applications programmers to come and build their businesses on [your tract of land]. This attracts users, who want to live there because of all the wonderful services and shops the programmers have built. This in turn causes more programmers to want to rent space for their businesses, to be near the customers. When this process gathers momentum, it's impossible to stop.

Once your city is established, owning the API is like being the king of the city. The king gets to make the rules: collecting tolls for entering the city, setting the taxes that the programmers and users have to pay, and taking first dibs on any prime locations (by keeping some APIs confidential for personal use). ${ }^{41}$

This Part discusses the general economic considerations bearing on whether and to what extent intellectual property ought to protect network features of systems technologies-those features that affect access to or interoperability with a system. It also presents three principles for tailoring intellectual property regimes and competition policy for network technologies.

There are two market failures in play in optimizing intellectual property protection. First, network features of system technologies, like any other technology, are subject to the classic appropriability problem. Without intellectual property protection, inventors of more advanced platform technologies will be subject to being undercut by new entrants who imitate the innovations without bearing $\mathrm{R} \& \mathrm{D}$ costs. First-mover advantages, effective marketing, trade secrecy, and other strategies might provide sufficient motivation for some R\&D, but there is reason to be concerned that the unregulated market will under-produce potentially high value, but risky and costly, innovation in network technologies.

Demand-side effects in network markets, however, complicate the conventional analysis of intellectual property protection. Because of the dynamics of network markets, some firms might be motivated to limit access to their platforms to reap the outsize profits from controlling a network market. This strategy, however, can hinder the realization of network benefits by raising prices, limiting access by third parties, and discouraging innovation

41. See Jerry Kaplan, Startup: A Silicon Valley Adventure 49-50 (1995) (explaining that "our value is the APIs" and "the real wars [in the computer industry] are over control of APIs" (quoting an industry remark)). 
because of the high barriers to entry. Consumers benefit when they and their devices, systems, and programs "speak" the most widely adopted platformthe lingua franca-or can translate that code into language their devices understand. This often provides for greater functionality, such as more software that will run on their platform and larger communication networks.

Second, widely adopted product standards can strand the industry on an obsolete platform. ${ }^{42}$ Consumers resist switching costs-from learning new tools and languages to acquiring new devices. They demand substantial improvements in efficiency or functionality to jettison comfortable, well-worn devices and software tools for new tools and systems.

Thus, the installed base built upon the dominant platform-reflected in durable goods and human capital (training) specific to the old standard-can create inertia that makes it much more difficult for any one producer to break away from the prevailing standard by introducing a noncompatible product, even if the new standard offers a significant technological improvement over the current standard. ${ }^{43}$ In this way, network externalities can retard innovation and slow or prevent adoption of improved product standards.

Therefore, companies seeking to leapfrog a widely adopted standard face substantial risk. They must not only invent an improved platform, but they must also devise and execute a successful strategy to migrate consumers from the dominant platform. They also face the challenge of encouraging other software and complementary product developers to build for the new platform. One strategy is to steeply discount the costs of the new platform or provide free access. This strategy is not sustainable unless the platform developer has ancillary revenue streams - such as bundled advertising or ties to other products and services-to cover their research, development, product, and support costs.

Intellectual property protection can contribute to and alleviate the network externality dilemma. On the one hand, intellectual property protection for the network features of computer technology can discourage realization of positive network externalities by limiting access to network technologies. The sponsor of a particular network technology can use intellectual property protection to exclude competitors or charge a high licensing fee for access, thereby raising costs. The intellectual property owner can also limit innovation by restricting how the network technology evolves. On the other hand, intellectual property protection can provide valuable incentives for

42. See generally Farrell \& Saloner, supra note 18.

43. See generally Farrell \& Saloner, supra note 20. 
overcoming bandwagon effects that entrench obsolete standards. ${ }^{44}$ Without the potential for a large reward, inventors contemplating innovative new platforms might not be willing to make the substantial, risky $R \& D$ and marketing investments needed to challenge, and hopefully leapfrog, the incumbent platform.

These considerations suggest three principles for intellectual property protection of APIs and other functional features of platform technologies: (A) a parsimony principle to prevent firms from establishing protection for product standards without providing a significant technological advance; (B) a proportionality principle to ensure that firms can appropriate a fair return on technological advances in platform innovation sufficient to overcome the excess inertia of network markets, but not so large as to stunt network externalities; and (C) a deterrence principle to discourage deceptive practices and overreach in network markets.

\section{A. Parsimony Principle: No Intellectual Property Protection FOR FunCTIONAL ATTRIBUTES ABSENT SigNifiCANT TECHNOLOGICAL ADVANCE}

Consumers benefit from access to platforms that produce network benefits. Those benefits can increase over time through positive feedback effects and the development of aftermarket enhancements and complementary products. The incentives for firms adopting product standards, however, are distorted. New entrants might choose an incompatible standard to differentiate their products from established brands, even where growing the established network would enhance consumer welfare. ${ }^{45}$

Intellectual property protection affects such choices by setting the ground rules for establishing proprietary platforms. Firms will be more inclined to build competing platforms where the thresholds for acquisition of intellectual property protection - and hence the power to exclude subsequent entrants and those seeking to bridge platforms - are low.

Thus, intellectual property regimes should discourage platform adoption choices that undermine realization of network externalities unless there is a large countervailing benefit, such as substantial technological advance. Affording meaningful intellectual property protection for network technologies without requiring a significant technological advance encourages wasteful differentiation and increases the risk of undeserved monopoly power. With easy access to intellectual property protections-for example, by merely using arbitrary lock-out codes-firms can fragment platforms that would

44. See Menell, supra note 23, at 1343.

45. See Katz \& Shapiro, supra note 11, at 425, 434-36; Katz \& Shapiro, supra note 21, at $822,830-33$. 
otherwise foster competition in the non-network product features and in downstream products competing on the platform. Through serendipity, first mover advantage, clever marketing, or simply luck, market power can emerge through positive feedback effects without discernible consumer benefits. Therefore, intellectual property law should not simply reward novel (but obvious) or expressive functional features of network goods or services. Rather, strong protection should be reserved for substantial advances.

\section{B. Proportionality PRINCIPLE: OVERCOMING EXCESS INERTIA Without Undue PRotection}

While low thresholds for intellectual property protection for network technologies undermine realization of network externalities, balanced protection for substantial technological advances may be necessary for entrants to overcome the strong inertial forces driving network markets. Switching costs discourage consumers from making the leap to a new platform. For network products and services, those costs can be particularly high due to network effects. The leap is likely not worth the cost for modest technological improvements. At some point, however, overall consumer welfare will be enhanced by migration to an alternative platform. The efficient tipping point depends on R\&D and marketing costs as well as the contours of consumer demand.

The excess inertia of network effects can hinder, delay, and possibly prevent the technological shift to a substantially more advanced technological platform. If all such advances were freely available to entrants, the free-rider problem would discourage the R\&D and marketing investment needed to displace the obsolete platform. Yet providing strong intellectual property protection for such advances can lead to robust returns as the market tips to the new platform.

The shift from "feature phones"-mobile phones "featuring" voice and text messaging with rudimentary Internet access-to true "smartphones" with email and robust web functionality illustrates the challenges and opportunities surrounding network markets. Through the 1990s, Motorola, Nokia, and a few other vendors established the first generation of mobile devices. Sun, Microsoft, and Symbian vied to establish the platform for mobile devices that integrated email and Internet capabilities. By 2005, Java's Micro Edition (ME) was faring well, with adoption by Palm and Blackberry.

As the first-generation smartphone battle was resolving, Apple was secretly investing heavily in an ambitious new platform. Intellectual property played a 
significant role in motivating Apple's R\&D. As Steve Jobs noted during the historic January 2007 iPhone announcement, "boy have we patented it!" 46

Meanwhile, Google was at work on its own skunkworks ${ }^{47}$ smartphone play: the Android smartphone platform. Given Google's concern that its success in search and online advertising could be displaced if Microsoft or Apple gained dominance in the shift to mobile devices, Google sought to develop an open platform that would perpetuate Google's dominance in search and other services on mobile devices. ${ }^{48}$

This standards war illustrates the dynamism of network markets as well as the complex role of intellectual property protection. In the space of just a few years, the market shifted dramatically from feature phones to rudimentary smartphones and then to advanced smartphones. By 2011, Apple and Google dominated the market. Intellectual property protection played a central role in encouraging investment, but also resulted in massive resources devoted to intellectual property acquisition, coalition building, standard setting on upstream technologies, and litigation.

There is no simple answer to the question of how much protection is enough, especially given the range of business strategies, institutions, and intellectual property regimes that can deliver appropriate returns on investment, the dynamism of network markets, and concerns about anticompetitive leveraging network technology dominance. Lichtman emphasizes strong property rights to promote platform competition, ${ }^{49}$ but this analysis assumes low transaction costs, overlooks consumers' cognitive limitations stemming from lock-in, and risks leveraging monopoly power and inhibiting cumulative innovation.

The optimal level of intellectual property protection has a dynamic quality, with the level of protection dissipating as network technologies and platforms become dominant. Menell recommends a limited patent-type regime to protect the functional features of computer software, although with shorter duration

46. Tim Worstall, Too Funny, Steve Jobs Invalidated an Apple Patent over Prior Art, FORBES (Sept. 27, 2013), https://www.forbes.com/sites/timworstall/2013/09/27/too-funny-stevejobs-invalidated-an-apple-patent-over-prior-art/ [https://perma.cc/4HDR-ZU3U].

47. See Fred Vogelstein, Dogfight: How Apple and Google Went to War AND STARTED A REVOLUTION 45 (2013). "Skunkworks" was derived from Lockheed's codenamed secret World War II project to develop a new fighter jet ("Skunk Works"), which was taken from Al Capp's Li'l Abner comic strip, a "skunkworks" project brings together a small group of highly skilled researchers to pursue radical innovations. See Menell, supra note 16, at $347-48$.

48. See Menell, supra note 16, at 357.

49. See Douglas Lichtman, Property Rights in Emerging Platform Technologies, 29 J. LEGAL STUD. 615, 615-20 (2000). 
and more flexibility to promote access to platforms that become widely adopted. ${ }^{50}$ Menell ${ }^{51}$ advocates a genericide-type doctrine, ${ }^{52}$ which could protect emerging platforms but give way to broader access when a platform becomes dominant and risks affording the proprietor the ability to leverage that control to hinder cumulative innovators. ${ }^{53}$ This analysis anticipated Microsoft's rise and its abusive market tactics in undermining Netscape and Sun. At the same time, scholars have opposed copyright protection for the functional and interoperable aspects of computer technology so as to avoid large returns to first movers that win a standards battle without offering significant technological innovation. ${ }^{54}$ Such limitations on copyright protection afford competitors freedom to use and build on unpatented methods of operation. In some circumstances, compulsory licensing of patents might be desirable. This can be achieved through injunctive relief.

The proportionality principle ensures that platform innovators who choose proprietary strategies (as opposed to more collaborative approaches) have the potential to reap significant rewards if they prevail in a standards competition, but that their ability to control the platform (and charge monopoly prices) declines as the network becomes entrenched. Such a regime creates optimal conditions for overcoming excess inertia while promoting the realization of network benefits. It also allows for competition to enhance and improve established platforms.

\section{Deterrence Principle: Discouraging Overreach With BALANCED REMEDIES}

Intellectual property law and competition policy should also protect against deceptive practices and leveraging intellectual property rights to control network markets. The integrity of standard-setting processes is particularly

50. See Menell, supra note 23.

51. See Peter S. Menell, An Analysis of The Scope of Copyright Protection for Application Programs, 41 STAN. L. REV. 1045, 1101-04 (1989).

52. A trademark can become generic and thereby lose protection if it becomes associated in the public's mind with a category of product rather than the source of a particular brand of the product. See, e.g., Murphy Door Bed Co., Inc. v. Interior Sleep Sys., Inc., 874 F.2d 95 (2d Cir. 1989) ("Murphy bed" for a bed that folds up into a wall cabinet); King-Seeley Thermos Co. v. Aladdin Indus., 321 F.2d 577 (2d Cir. 1963) (“Thermos" for a vacuum insulated bottle).

53. See Richard N. Langlois, Technological Standards, Innovation, and Essential Facilities: Toward a Schumpeterian Post-Chicago Approach, in DYNAMIC COMPETITION AND PUblic Policy: TeChnology, InNovation, And Antitrust Issues 193 (Jerry Ellig ed., 2001).

54. See Menell, supra note 23; Dennis S. Karjala, Copyright, Computer Software, and the New Protectionism, 28 JuRIMETRICs 33, 62-72 (1987); Pamela Samuelson, Randall Davis, Mitchell D. Kapor \& J. H. Reichman, A Manifesto Concerning the Legal Protection of Computer Programs, 94 Colum. L. REV. 2308, 2332-64 (1994). 
critical to efficient collaboration among enterprises and innovators working in network industries. The choice of standards depends on a range of factors, including potential restrictions on practicing technological standards. Hence, standard-setting bodies should require disclosure of all potential intellectual property encumbrances or, at a minimum, advance commitment by SSO members to licensing such technologies on fair and reasonable terms. Courts should penalize efforts to reduce transparency in standard-setting processes and take failure to abide by such commitments into consideration in enforcing patent rights.

Antitrust law and competition policy should also take network effects into account in assessing monopoly power, scrutinizing collaborations and contractual agreements, and fashioning remedies. The consumer, competitive, and innovation ramifications of network markets are especially complex. What might appear to be benign and welfare-improving behaviors-such as integrating a "free" browser into an operating system product or bundled aftermarket services-might ultimately lead to monopolization of important emerging and downstream markets. Hence, antitrust law must be vigilant in assessing the dynamism and path-dependence of network technologies. For example, advance determination of licenses for standard-essential patents can promote competition in downstream products and services. In some circumstances, antitrust authorities should tolerate some collusive behaviorssuch as ex-ante negotiation of FRAND license rates by SSOs-that resemble forbidden price-setting. The Sherman Antitrust Act bars contracts and conspiracies that unreasonably restrain competition. In network markets, some collaboration promotes economic efficiency.

The crafting of remedies to combat abusive and anti-competitive behavior in network markets requires careful consideration of effects on consumers and competitors. Once a standard has taken root and is generating substantial network benefits, traditional remedies - such as enjoining the offensive activities or breaking up dominant firms - can cause adverse effects on the consumers who have adopted the standard as well as other downstream users - such as programmers and competitors who have incurred sunk costs in joining the platform. Leveraging intellectual property rights to control network markets might also produce countervailing innovative efficiencies. Hence, antitrust authorities and courts should consider remedies that promote the realization of network benefits while also promoting enhanced competition and innovation. In some circumstances, these considerations favor compulsory licenses, which can be flexible and adaptable, over injunctive remedies. 


\section{INTELLECTUAL PROPERTY PROTECTION FOR NETWORK FEATURES}

In view of the tremendous economic significance of controlling access to systems technologies by exploiting demand-side effects and excluding competition in complementary goods and services, such as repair services, replacement parts, and ancillary markets (e.g., advertising and consumer data), platform developers and entrepreneurs have sought to use intellectual property to protect APIs and other means to exclude competitors from their platforms and systems. As an alternative approach, computer programmers and a growing number of commercial enterprises in the open-source community have deployed intellectual property protection as a tool for sharing technology and precluding proprietary control of core Internet and computer operating system technologies.

Since the principal forms of intellectual property protections developed long before the advent of digital technology, which made network effects so important, the intellectual property statutes do not expressly reflect the aforementioned policy principles for APIs and other functional features of platform technologies. Nonetheless, the mixed statutory/common law heritage of intellectual property law ${ }^{55}$ has afforded courts discretion to interpret statutory provisions, adapt common law doctrines, and apply equitable enforcement principles to address network effects. Moreover, more recent legislation has integrated network economics into intellectual property law. ${ }^{56}$

Although patents have long protected platform technologies, such as electrical standards (e.g., AC/DC, phonogram, color television, and telecommunications), ${ }^{57}$ the contours of intellectual property protection for network features of systems and platforms centers around software technology. Trade secrecy and contract law provided relatively effective protection for much of the software developed during the mainframe and minicomputer eras. And although advances in computer hardware fell squarely within the patent domain, there were significant doubts about the patentability of computer software into the 1990s. Hence, as microcomputers emerged, which spurred retail distribution of computer software, copyright law emerged as the primary battleground for computer software by the mid-1980s.

55. See Peter S. Menell, The Mixed Heritage of Federal Intellectual Property Law and Ramifications

for Statutory Interpretation, in INTELLECTUAL PROPERTY AND THE COMMON LAW 63 (Shyamkrishna Balganesh ed., 2013).

56. See infra Section V.B.4 (exploring the DMCA interoperability exemption).

57. See SHAPIRO \& VARIAN, supra note 5, at 210-23. 
This Part begins by discussing how trade secrecy can protect the network features of systems technologies. It then traces the evolution of copyright protection for computer software. Almost all of the major computer software battles have focused on the extent to which copyright protection afforded protection to the network features of computer software. Section V.C discusses the role of trademark and related protections for network technologies. Section V.D examines the role of patent protection for network technologies, which emerged as a more robust and controversial form of protection for computer software in the 1990s.

\section{A. Trade SECREt PRotection}

Trade secret protection protects against the misappropriation of confidential information that is subject to reasonable efforts to maintain secrecy, such as security and non-disclosure agreements with employees and contractors. ${ }^{58}$ Trade secret protection can last indefinitely, but once trade secrets become public, they lose protection.

Trade secret protection came into common usage in the software industry as a tool for protecting algorithms, software design, and coding-including APIs. Trade secret protection of passwords is also commonly used today to control access to websites and cloud servers.

Trade secret protection does not provide absolute protection for information. It only protects against misappropriation through improper means and unauthorized disclosure. Therefore, competitors do not violate trade secrecy protection through reverse engineering of publicly available products and websites. The reverse engineering limitation on trade secret protection thus exposes the trade secret owner to free riding by others. This limitation, however, strikes a salutary balance between protection on the one hand and competition and the dissemination of knowledge on the other. ${ }^{59}$ The trade secret owner can "purchase" greater protection against this risk by investing in higher levels of security (e.g., more effective encryption for software-encoded technology). The inventor can also pursue patent protection, which proscribes reverse engineering, although only for the limited duration of the patent, and mandates disclosure of the invention to the public. By declining to pursue patent protection (or failing to satisfy the requirements

58. See Menell ET AL., supra note 2, at 40-152.

59. See William M. Landes \& Richard A. Posner, The ECOnOmic Structure of Intellectual Property Law (2003); Pamela Samuelson \& Suzanne Scotchmer, The Law and Economics of Reverse Engineering, 111 YALE L.J. 1575, 1649-61 (2002); see generally Donald S. Chisum, Rochelle Cooper Dreyfuss, Paul Goldstein, Robert A. Gorman, Dennis S. Karjala, Edmund W. Kitch, Peter S. Menell, Leo J. Raskind, Jerome H. Reichman \& Pamela Samuelson, LaST Frontier Conference Report on Copyright Protection of Computer Software, 30 JURIMETRICS 15, 16-18 (1989). 
thereof), however, inventors should not be able to secure potentially perpetual rights in technologies merely by encrypting them or otherwise obscuring how they function. To do so would undermine the larger balance of the federal intellectual property system.

As the next Section explains, courts have interpreted copyright law to permit multiple reproductions of copyrighted software programs as a means for reverse engineering unprotected (by copyright), but secret, elements of code necessary for interoperability.

\section{B. COPYRIGHT PROTECTION}

As the proliferation of microcomputers seeded a market for computer programs, software entrepreneurs saw copyright as an effective strategy to protect their programs from unauthorized reproduction and distribution. Computer software, however, does not fit easily within the copyright mold. Copyright law had long denied protection to functional elements. Although written in text, computer software provides the gears and levers for digital machines - which fits more naturally within the utility patent system. ${ }^{60}$

The rapid emergence of the computer software marketplace in the early 1970s posed a dilemma for intellectual property policymakers. Computer software could be expensive to develop and was easily pirated, creating a severe appropriability problem for the nascent software industry. ${ }^{61}$ Patent law, which had long served as the primary form of protection for technological advances in machines and processes, was thought to be too costly, time-consuming, stringent, and uncertain as a means for protecting software products against piracy. ${ }^{62}$ Copyright law had long provided an effective means of protecting literary works from piracy, but its doctrines excluding ideas and functional elements from protection raised serious questions about its appropriateness for protecting inherently utilitarian works. Copyright's low threshold for protection (mere originality), broad array of rights (including the right to adapt), and long duration created a high risk of overbroad protection for computer software products, in direct opposition to the parsimony principle. On the other hand, copyright law's limiting principles, such as the ideaexpression dichotomy (denying copyright protection to expression that

60. Cf. Baker v. Selden, 101 U.S. 99, 102 (1879) ("The claim to an invention or discovery of an art or manufacture must be subjected to the examination of the Patent Office before an exclusive right therein can be obtained; and it can only be secured by a patent from the government."). (1976).

61. See Bill Gates, An Open Letter to Hobbyists, 2 HomeBrew Computer Club Newsl. 2

62. See Menell, supra note 23 , at 1347-51. 
encumbers the use of ideas) and the fair use doctrine, provided tools for aligning copyright protection with the parsimony principle.

The interplay of copyright protection and network effects has played out on several fronts during the past four decades. Section V.B.1 explains the principal legislation undergirding copyright protection for computer software. Section V.B.2 traces the development of software copyright jurisprudence relating to APIs through 2010. Section V.B.3 explores software licensing and the emergence and growth of the free and open source movements-key drivers of network technology markets. Section V.B.4 explores the interoperability exception to the anti-circumvention provisions added to the copyright law in 1998. Section V.B.5 picks up where Section V.B.2 left off by examining the Oracle v. Google litigation. ${ }^{63}$ Section V.B.6 examines copyright protection for standards and codes.

1. Software Copyright Legislation: The Copyright Act of 1976, the CONTU Report, and the 1980 Amendments

The software protection controversy of the early 1970s emerged at an inopportune time. Congress had been working for nearly two decades to overhaul the Copyright Act of 1909 and was nearing closure in the early to mid-1970s. Faced with the challenge of fitting computer and other new information technologies under the existing umbrella of intellectual property protection, Congress established the National Commission on New Technological Uses of Copyrighted Works (CONTU) to study the implications of the new technologies and recommend revisions to federal intellectual property law. As a stopgap, Congress included computer software within the scope of "literary works" in the Copyright Act of 1976 ("1976 Act"). The House Report explains:

The term "literary works" does not connote any criterion of literary merit or qualitative value: it includes catalogs, directories, and similar factual, reference, or instructional works and compilations of data. It also includes computer data bases, and computer programs to the extent that they incorporate authorship in the programmer's expression of original ideas, as distinguished from the ideas themselves. ${ }^{64}$

63. See Oracle Am., Inc. v. Google Inc., 750 F.3d 1339 (Fed. Cir. 2014); Oracle Am., Inc. v. Google Inc., 872 F. Supp. 2d 974 (N.D. Cal. 2012).

64. H.R. REP. No. 94-1476, at 54 (1976) (emphasis added). 
Other provisions of the 1976 Act, however, maintained traditional exclusions for ideas and functional features. ${ }^{65}$

The CONTU Final Report concluded that copyright law should protect the intellectual work embodied in computer software, notwithstanding the fundamental principle that copyright cannot protect "any idea, procedure, process, system, method of operation, concept, principle, or discovery" and the Supreme Court's foundational Baker v. Selden decision. ${ }^{66}$ Nonetheless, CONTU recommended that Congress immunize rightful possessors of a computer program from liability for using the program (which typically results in reproduction of computer code) and making a backup copy of computer programs, which Congress largely adopted in $1980 .{ }^{67}$

In keeping with copyright law's fundamental limiting principles, the CONTU Final Report explained that while "one is always free to make a machine perform any conceivable process (in the absence of a patent), [] one is not free to take another's program," subject to copyright's limiting doctrines-originality and the idea-expression dichotomy. ${ }^{68}$ The Report further explained that

[t] "idea-expression identity" exception provides that copyrighted language may be copied without infringing when there is but a limited number of ways to express a given idea. This rule is the logical extension of the fundamental principle that copyright cannot protect ideas. In the computer context this means that when specific instructions, even though previously copyrighted, are the only and essential means of accomplishing a given task, their later use by another will not amount to an infringement. ${ }^{69}$

Thus, while recognizing important limitations on copyright protection for computer software, including the $\int 102(\mathrm{~b})$ limitations, Congress intended that software programmers would garner protection for their programming design and coding choices to the extent that the expression was separable from the

65. 17 U.S.C. \ 102(b) (2018) ("In no case does copyright protection for an original work of authorship extend to any idea, procedure, process, system, method of operation, concept, principle, or discovery.").

66. Id.; see Baker v. Selden, 101 U.S. 99 (1879); see also NAT’L COMM’N ON NEW Technological Uses of Copyrighted Works (CONTU), Final Report of the National COMmission on New TeChNOlogical Uses of COPYRighted Works 18-19 (1978) [hereinafter CONTU REPORT].

67. 17 U.S.C. $\iint 101$ (adding a definition of "computer program"), 117 (providing for limitations on exclusive rights on computer programs, including the making of additional copies for archival purposes).

68. See CONTU REPORT, supra note 66, at 20.

69. $I d$. 
underlying ideas. In this way, the general programming ideas and unoriginal programming choices remain free for others to use while the creative effort in particularized programming choices and compilations, especially in complex programs, gains protection from copyists.

\section{Software Copyright Jurisprudence: The First Wave}

The 1976 Copyright Act, as well as the CONTU Report, pushed the availability and scope of copyright protection for computer software to the courts. The treatment of APIs under copyright law emerged over the next two decades as courts interpreted and applied the $\$ 102(\mathrm{~b})$ limitations (including the idea-expression dichotomy), infringement standards, the fair use defense, and other legal doctrines and standards. Courts confronted battles across various software markets-from microcomputer operating systems to job scheduling software for mainframe computers, mobile phone networks, computer-user interfaces, video game devices, printer cartridges, garage door openers, and all manner of application programs (such as business systems, design programs, video games, and spreadsheets). Nearly every major software copyright litigation involved interoperability elements.

After an inauspicious start, the federal courts implemented a balanced framework for both protecting computer software against piracy and interpreting the idea-expression doctrine to ensure that copyright law excludes functional features of computer technology. ${ }^{70}$ These decisions effectuated the subtle balance to which the CONTU Report referred. The courts came to appreciate that "creativity" must be understood contextually. While programming a computer can unquestionably be termed "creative" in a general sense, it is not necessarily "creative" in a copyright sense. Just as the design of an efficient mechanical machine can be creative, such devices are not eligible for copyright protection unless the aesthetic features can be separated from the functional attributes. ${ }^{71}$ Lines of code are the gears and levers of digital machines. The fact that computer software, like a sculptural work, is eligible for copyright protection does not authorize protection for functional features.

The courts came to recognize that APIs have significant functional dimensions. They serve in many contexts as the basis for interoperability of

70. See generally Peter S. Menell, An Epitaph for Traditional Copyright Protection of Network Features of Computer Software, 43 ANTITRUST BULL. 651, 661-72 (1998).

71. 17 U.S.C. $\int 101$ (“ 'Pictorial, graphic, and sculptural works' include two-dimensional and three-dimensional works ... the design of a useful article ... shall be considered a pictorial, graphic, or sculptural work only if, and only to the extent that, such design incorporates pictorial, graphic, or sculptural features that can be identified separately from, and are capable of existing independently of, the utilitarian aspects of the article.”). 
computer technologies. The First Circuit held that the particular functional specifications, as opposed to the implementing code, can be fairly characterized as "methods of operation." Although the Supreme Court's split decision in Lotus v. Borland left some uncertainty, ${ }^{72}$ the resolution of that litigation marked the end of the major API copyright litigations that had raged since the early 1980s.

This Section traces that evolution. Section a) examines the emergence of jurisprudence excluding functional and network features of computer software. Section b) explores the related issue of whether competitors can reproduce computer software as a means of learning unprotectable code elements.

a) Unprotectability of Functional and Network Features

The first major cases to address copyright protection for interoperable features of computer software pitted Apple Computer Corporation, then a young, break-out microcomputer company, against cavalier, unscrupulous competitors offering discount "interoperable" Apple II clones. ${ }^{73}$ The clone makers quickly entered the market by simply copying, bit by bit, Apple's operating system and application programs.

The defendants in these cases argued that copyright protection did not extend to non-human readable (object code) formats of computer software and that the idea-expression doctrine barred copyright protection for operating system programs. They further argued that copyright protection should not stand in the way of their selling computers that can run programs written for the Apple II. The courts had little trouble validating Apple's complaint that verbatim copying of millions of bits of code constituted copyright infringement. The 1976 Act, in conjunction with the CONTU Report, clearly extended copyright protection in these circumstances.

Unfortunately, the Third Circuit's decision included language suggesting that copyright protection could encompass the functional requirements for interoperability: "total compatibility with independently developed application programs ... is a commercial and competitive objective which does not enter

72. See Lotus Dev. Corp. v. Borland Int'l, 516 U.S. 233 (1996) (affirming, without opinion by an equally divided vote, the First Circuit's decision holding that the menu command structure for a spreadsheet is an uncopyrightable method of operation under $\left.\int 102(\mathrm{~b})\right)$.

73. See Apple Comput., Inc. v. Franklin Comput. Corp., 545 F. Supp. 812 (E.D. Pa. 1982), rev'd, 714 F.2d 1240 (3d Cir. 1983); Apple Comput., Inc. v. Formula Int'l, Inc., 562 F. Supp. 775 (C.D. Cal. 1983), aff'd, 725 F.2d 521 (9th Cir. 1984). 
into the somewhat metaphysical issue of whether particular ideas and expressions have merged." ${ }^{74}$ Since two entirely different programs can achieve the same "certain result $[\mathrm{s}]$ " 75 - for example, generate the same set of protocols needed for interoperability - the court was not justified in making such an expansive statement about the scope of copyright protection for computer program elements. CONTU was clear that "one is always free to make the machine do the same thing as it would if it had the copyrighted work placed in it, but only by one's own creative effort rather than by piracy." ${ }^{\prime 76}$ Given the verbatim copying of millions of bits of object code, there was no need to address the interoperability issue. The defendant failed to explain which elements of the program were protectable and which were not.

The Third Circuit's decision in Whelan Associates, Inc. v. Jaslow Dental Laboratory, Inc. ${ }^{77}$ further expanded copyright protection for computer software. In that case, Jaslow Dental Laboratory had hired Whelan Associates, a custom software company, to develop a computer program to organize its bookkeeping and administrative tasks. When Jaslow developed and marketed its own program for managing a dental laboratory, Whelan sued Jaslow for copyright infringement. The evidence at trial showed that although Jaslow had not literally copied Whelan's code, there were overall structural similarities between the two programs. As a means of distinguishing protectable expression from unprotectable idea, the court reasoned:

[T] he purpose or function of a utilitarian work. would be the work's idea, and everything that is not necessary to that purpose or function would be part of the expression of the idea.... Where there are various means of achieving the desired purpose, then the particular means chosen is not necessary to the purpose; hence, there is expression, not idea. ${ }^{78}$

In applying this rule, the court defined the idea as "the efficient management of a dental laboratory," which countless programs could express. ${ }^{79}$ Drawing the idea-expression dichotomy at such a high level of abstraction implied an expansive scope of copyright protection. Although the case did not directly address copyright protection for interoperable features of computer code, the court's mode of analysis expanded the scope of copyright protection to all aspects of computer programs. If everything below the general purpose of the program were protectable under copyright law, then it would follow that

74. Apple Comput. v. Franklin Comput. Corp., 714 F.2d 1240, 1253 (3d Cir. 1983).

75. 17 U.S.C. $\int 101$ (definition of "computer program").

76. See CONTU REPORT, supra note 66, at 21.

77. 797 F.2d 1222 (3d Cir. 1986).

78. Id. at 1236 (emphasis in original) (citations omitted).

79. Id. at 1236 n.28. 
particular protocols were protectable because there would be other ways to accomplish the program's same general purpose. Such a result would effectively bar competitors from developing interoperable programs and computer systems.

Commentators roundly criticized the Whelan test, ${ }^{80}$ and other courts developed alternative approaches. A few months after Whelan, the Fifth Circuit confronted a similar claim of copyright infringement based upon structural similarities between two programs designed to provide cotton growers with information regarding cotton prices and availability, accounting services, and a means for conducting cotton transactions electronically. ${ }^{81}$ In declining to follow the Whelan approach, the court found that the similarities in the programs were dictated largely by standard practices in the cotton marketwhat the court called "externalities" - such as the "cotton recap sheet" for summarizing basic transaction information, which constitute unprotectable ideas. The court found persuasive the decision in Synercom Technology, Inc. v. University Computing Co., which analogized the "input formats" of a computer program (the organization and configuration of information to be inputted into a computer) to the "figure- $\mathrm{H}$ " pattern of an automobile stick shift. ${ }^{82}$

Drawing on the Fifth Circuit's approach and Judge Learned Hand's foundational test for analyzing copyright infringement, ${ }^{83}$ the Second Circuit crafted what has become the leading framework for analyzing infringement of computer software code. ${ }^{84}$ Computer Associates (CA), a leading mainframe software provider, had developed a job-scheduling program (SCHEDULER) for IBM mainframe computers. Part of the success of this program was that it had a sub-component (ADAPTER) which interoperated with any of the three IBM mainframes. Thus, the user did not need to customize its programs for each of the IBM mainframes. CA's ADAPTER program ensured that programs written for SCHEDULER would run on any of the three IBM mainframes.

80. See Chisum et al., supra note 59, at 20-21; Menell, supra note 51, at 1074; Note, Steven R. Englund, Idea, Process, or Protected Expression?: Determining the Scope of Copyright Protection of the Structure of Computer Programs, 88 MiCH. L. REV. 866, 881 (1990).

81. See Plains Cotton Coop. Ass'n v. Goodpasture Comput. Serv., Inc., 807 F.2d 1256 (5th Cir. 1987).

82. 462 F. Supp. 1003, 1013 (N.D. Tex. 1978).

83. See Nichols v. Universal Pictures Corp., 45 F.2d 119 (2d Cir. 1930) (espousing the idea-expression doctrine, that ideas are not copyrightable but expression of those ideas may be subject to copyright protection).

84. See Comput. Assocs. Int'l v. Altai, Inc., 982 F.2d 693 (2d Cir. 1992). 
CA sued Altai, a competitor that pursued a similar strategy for designing its job scheduling software for the IBM mainframes. Unbeknownst to Altai's management, one of its key programmers copied 30\% of ADAPTER code into Altai's job scheduling software product. When Altai management learned of the copying, the company initiated a "clean room" process to insulate its programmers from copyright-protected code so as to ensure that the resulting program interoperated with the IBM mainframes without copying any ADAPTER code. ${ }^{85}$

Altai accepted responsibility for copyright infringement based on the early version. Nonetheless, drawing on the Third Circuit's Whelan decision, CA claimed that the clean room version was also infringing due to structural similarities at various levels, such as flow charts, inter-modular relationships, parameter lists, and macros. The Second Circuit rejected Whelan's approach. As an alternative, it put forth a systematic analytical framework for determining copyright infringement of computer code:

In ascertaining substantial similarity ... a court would first break down the allegedly infringed program into its constituent structural parts. Then, by examining each of these parts for such things as incorporated ideas, expression that is necessarily incidental to those ideas, and elements that are taken from the public domain, a court would then be able to sift out all non-protectable material. Left with a kernel, or possibly kernels, of creative expression after following this process of elimination, the court's last step would be to compare this material with the structure of an allegedly infringing program. ${ }^{86}$

The court's "abstraction-filtration-comparison" test recognized that an idea could exist at multiple levels of a computer program and not solely at the most abstract level. Furthermore, the ultimate comparison is not between the programs in their entirety. Rather, courts must focus solely on whether protectable elements of the program were copied. Of most importance for fostering interoperability, the court held that copyright protection did not extend to those program elements where the programmer's "freedom to choose" is

circumscribed by extrinsic considerations such as (1) the mechanical specifications of the computer on which a particular program is intended to run; (2) compatibility requirements of other programs with which a program is designed to operate in conjunction; (3) computer manufacturers' design standards; (4) demands of the

85. P. Anthony Sammi, Christopher A. Lisy \& Andrew Gish, Good Clean Fun: Using Clean Room Procedures in Intellectual Property Litigation, 25 INTELL. PROP. \& TECH. L.J. 3, 6 (2013).

86. Comput. Assocs. Int'l, 982 F.2d at 706. 
industry being serviced; and (5) widely accepted programming practices within the computer industry. ${ }^{87}$

Directly rejecting the Third Circuit's dictum in Apple v. Franklin ${ }^{88}$ that achieving "total compatibility with independently developed application programs ... is a commercial and competitive objective which does not enter into the somewhat metaphysical issue of whether particular ideas and expressions have merged," the Second Circuit recognized that external factors such as interface specifications, de facto industry standards, and accepted programming practices are not protectable under copyright law. The formulation of the Second Circuit test judges these external factors when the allegedly infringing activities (i.e., ex-post) occur, not when the first program is written. The court emphasized that the first company to write a program for a particular application should not be able to " lock up' basic programming techniques as implemented in programs to perform particular tasks." 89

Other circuits embraced the Second Circuit's Altai framework. ${ }^{90}$ The Altai case addressed programmers' freedom to write code to interoperate with externally established APIs - in that case by IBM. IBM had not challenged CA's or Altai's use of its interface specifications. It welcomed other companies to develop software for its mainframes. Thus, the case did not specifically address whether the API developer could assert a copyright infringement claim based on unauthorized use of their interface specifications. That issue would emerge in a series of cases involving video games and spreadsheets.

The Ninth Circuit's decision in Sega Enterprises Ltd. v. Accolade, Inc. expressly recognized the legitimacy of deciphering and copying particular lock-out codes for purposes of developing interoperable products. ${ }^{91}$ Sega developed a successful video game platform (Genesis) for which it licensed access to video game developers. Accolade, a video game manufacturer, wanted to distribute versions of its game on the Genesis platform. It did not, however, want to limit distribution exclusively to Genesis, as Sega required. Rather than license access to Sega's code, Accolade reverse engineered the access code through a painstaking effort that entailed making hundreds of intermediate copies of

87. Id. at $709-10$. 1983).

88. See Apple Comput., Inc. v. Franklin Comput. Corp., 714 F.2d 1240, 1253 (3d Cir.

89. See Comput. Assocs. Int'l, 982 F.2d at 712 (quoting Menell, supra note 51, at 1087).

90. See Gates Rubber Co. v. Bando Chem. Indus., Ltd., 9 F.3d 823, 836-43 (10th Cir. 1993); Eng'g Dynamics, Inc. v. Structural Software, Inc., 26 F.3d 1335 (5th Cir. 1994); Apple Comput., Inc. v. Microsoft Corp., 35 F.3d 1435 (9th Cir. 1994); Bateman v. Mnemonics, Inc., 79 F.3d 1532, 1547 (11th Cir. 1996); Mitel, Inc. v. Iqtel, Inc., 124 F.3d 1366 (10th Cir. 1997).

91. 977 F.2d 1510 (9th Cir. 1993). 
Sega's computer code. Accolade then incorporated only those code elements (approximately 25 bytes in games containing between 500,000 and 1.5 million bytes) that were necessary to achieve interoperability with the Genesis platform into Accolade game cartridges.

Sega sued Accolade for copyright infringement. Given the relatively small amount of Sega code in the Accolade game cartridges, Sega focused its copyright claim on Accolade's reproduction of the entirety of Sega's program code for purposes of isolating those code elements needed to interoperate with the Genesis console. The district court rejected Accolade's argument that such intermediate copies - made solely for the purpose of reverse engineering the platform-constituted fair use and granted a preliminary injunction. The Ninth Circuit held that "disassembly of object code in order to gain an understanding of the ideas and functional concepts embodied in the code is a fair use that is privileged by section 107 of the Act." 92 Balancing these factors, the Ninth Circuit ruled that "the functional requirements for compatibility with the Genesis [video game console are] aspects of Sega's programs that are not protected by copyright." 93 In effect, the court held that copyright law does not protect the particular code or process needed for interoperating with a copyrighted computer program (such as lockout code). The Ninth Circuit reaffirmed and expanded the Sega decision in Sony Computer Entertainment, Inc. v. Connectix Corp. ${ }^{94}$

The Northern District of California and the Ninth Circuit applied the Altai framework to the graphical user interface features of a computer program in Apple Computer, Inc. v. Microsoft Corp. ${ }^{95}$ Apple alleged that Microsoft's Windows operating system infringed copyrights in the desktop graphical user interface of its Macintosh computer system. A licensing agreement authorizing Microsoft to use aspects of Apple's graphical user interface muddied the copyright issue. The court determined, however, that the licensing agreement was not a complete defense to the copyright claims and therefore undertook an analysis of the scope of copyright protection for a large range of audiovisual elements of computer screen displays.

In framing the analysis, the district court expressly recognized the relevance of network externalities and the cumulative nature of innovation to the scope of copyright protection:

92. Id. at 1518 .

93. Id. at 1522 (citing 17 U.S.C. $\int 102(\mathrm{~b})$ ).

94. 203 F.3d 596 (9th Cir. 2000).

95. 799 F. Supp. 1006 (N.D. Cal. 1992), aff'd in part, rev'd in part, 35 F.3d 1435 (9th Cir. 1994). 
Copyright's purpose is to overcome the public goods externality resulting from the non-excludability of copier/free riders who do not pay the costs of creation. Peter S. Menell, An Analysis of the Scope of Copyright Protection for Application Programs, 41 STAN. L. REV. 1045, 1059 (1989). But overly inclusive copyright protection can produce its own negative effects by inhibiting the adoption of compatible standards (and reducing so-called "network externalities"). Such standards in a graphical user interface would enlarge the market for computers by making it easier to learn how to use them. Id. at 106770. Striking the balance between these considerations, especially in a new and rapidly changing medium such as computer screen displays, represents a most ambitious enterprise. Cf Lotus Dev. Corp. v. Paperback Software Int'l, 740 F. Supp. 37 (D. Mass. 1990).

While the Macintosh interface may be the fruit of considerable effort by its designers, its success is the result of a host of factors, including the decision to use the Motorola 68000 microprocessor, the tactical decision to require uniform application interfaces, and the Macintosh's notable advertising. And even were Apple to isolate that part of its interface's success owing to its design efforts, lengthy and concerted effort alone "does not always result in inherently protectible expression." [quoting Computer Associates v. Altai, 982 F.2d at 711.]

By virtue of having been the first commercially successful programmer to put these generalized features together, Apple had several years of market dominance in graphical user interfaces until Microsoft introduced Windows 3.0, the first DOS-based windowing program to begin to rival the graphical capability of the Macintosh .... To accept Apple's "desktop metaphor" /"look and feel" arguments would allow it to sweep within its proprietary embrace not only Windows and NewWave but, at its option, also other desktop graphical user interfaces which employ the standardized features of such interfaces, and to do this without subjecting Apple's claims of copyright to the scrutiny which courts have historically employed. Apple's copyrights would hold for programs in existence now or in the future-for decades. One need not profess to know for sure where should lie the line between expression and idea, between protection and competition to sense with confidence that this would afford too much protection and yield too little competition.

The importance of such competition, and thus improvements or extensions of past expressions, should not be minimized. The Ninth Circuit has long shown concern about the uneasy balance which copyright seeks to strike: "[w] hat is basically at stake is the extent of the copyright owner's monopoly_-from how large an area of activity 
did Congress intend to allow the copyright owner to exclude others?"96

The court found that most of the similar iconsbetween Apple's graphical user interface and Microsoft's Windows that were not authorized by the licensing agreements were either not lacking originality or subject to one or more of copyright's limiting doctrines. Drawing on the principle that compilations of largely uncopyrightable elements are only protected against "bodily appropriation of expression," "the court applied a "virtual identity" standard to compare the works as a whole and determined that no infringement had occurred. ${ }^{98}$ On appeal, the Ninth Circuit affirmed the district court's dissection of the works to determine which elements are protectable, its filtering of unprotectable elements, and its application of the "virtual identity" standard. ${ }^{99}$

The copyrightability of command systems for computer software arose most directly in litigation surrounding spreadsheet technology. Building upon the success of the VisiCalc program developed for the Apple II computer, Lotus Corporation marketed an enhanced operating spreadsheet program incorporating many of VisiCalc's features and commands into its 1-2-3 program for the IBM PC platform. Lotus 1-2-3 quickly became the market leader for spreadsheets running on IBM and IBM-compatible machines, and knowledge of the program became a valuable skill in the accounting and management fields. The 1-2-3 command hierarchy was particularly attractive because it logically structured more than 200 commands (see Figure 1). Users could create custom programs (called macros) to automate particular accounting and business planning tasks. Businesses and users increasingly became "locked-in" to the 1-2-3 command structure as they invested time to learn the system and their libraries of macros grew. ${ }^{100}$ By the late 1980s, software developers seeking to enter the spreadsheet market could not ignore the large premiums that consumers placed on their investments in the 1-2-3 system. ${ }^{101}$

96. Apple Comput., Inc., 799 F. Supp. at 1025-26 (quoting Herbert Rosenthal Jewelry Corp. v. Kalpakian, 446 F.2d 738, 742 (9th Cir. 1971)).

97. See Harper House, Inc. v. Thomas Nelson, Inc., 889 F.2d 197, 205 (9th Cir. 1989).

98. See Apple Comput., Inc. v. Microsoft Corp., 35 F.3d 1435, 1446 (9th Cir. 1994) (holding that "[u]nder Harper House and Frybarger [v. International Business Machines Corp., 812 F.2d 525 (9th Cir. 1987)], there can be no infringement unless the works are virtually identical").

99. See id. at 1446-47.

100. See generally Gandal, supra note 4.

101. See Menell, supra note 70 , at 697. 
Figure 1

Lotus 1-2-3 Menu Command Hierarchy

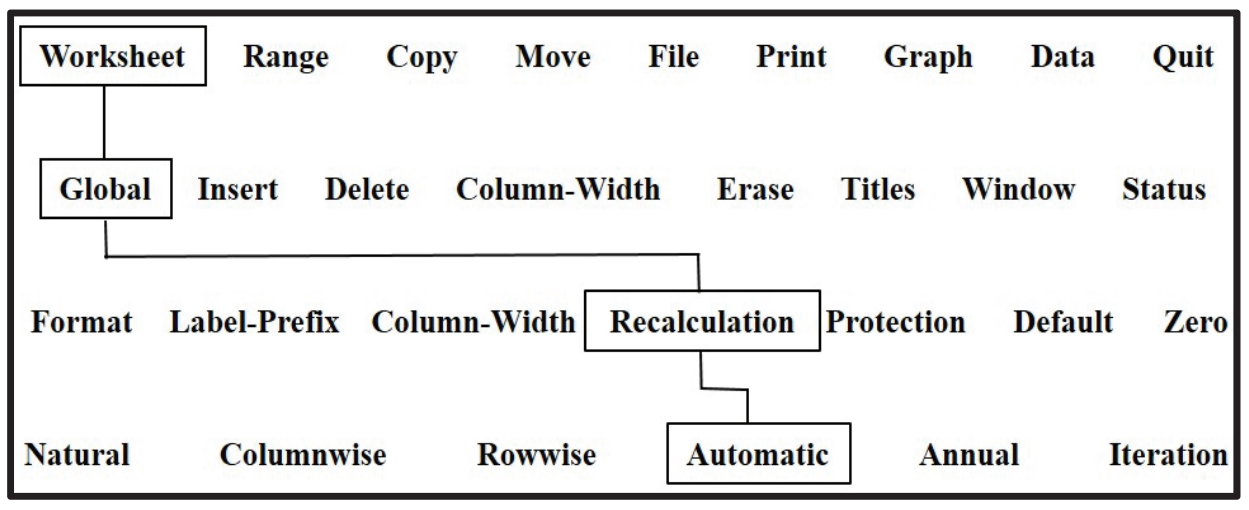

After three years of intensive development efforts, Borland International, developer of several successful software products including Turbo Pascal and Sidekick, introduced Quattro Pro, its entry into the spreadsheet market. ${ }^{102}$ Quattro Pro offered improved design and graphics over Lotus 1-2-3. Computer magazines praised its innovation. ${ }^{103}$ Quattro Pro offered a new interface for its users, which many preferred over the 1-2-3 interface. Nonetheless, because of the large number of users already familiar with the 12-3 command structure and those who had made substantial investments in developing 1-2-3 macros, Borland considered it essential to offer an operational mode based on the 1-2-3 command structure as well as macro compatibility. Nonetheless, Borland's visual representation of the 1-2-3 command mode substantially differed from the 1-2-3 screen displays.

Lotus sued Borland for copyright infringement based on Quattro Pro's emulation of the 1-2-3 menu command hierarchy. ${ }^{104}$ The First Circuit viewed the case as one of first impression: "[w] hether a computer menu command hierarchy constitutes copyrightable subject matter." 105 The court distinguished Altai as dealing with protection of computer code as opposed to the results of such code. Instead, the First Circuit saw the subject matter of the Lotus case as a "method of operation" falling directly within the exclusions from copyright

102. See generally Peter S. Menell, Envisioning Copyright Law's Digital Future, 46 N.Y.L. SCH. L. REV. 63, 91-93 (2003) (providing background on Borland and the Lotus v. Borland litigation).

103. See Peter S. Menell, An Epitaph for Traditional Copyright Protection of Network Features of Computer Software, 43 ANTITRUST Bull. 651, 698 n.137 (1998).

104. See Lotus Dev. Corp. v. Borland Int'l, Inc., 799 F. Supp. 203 (D. Mass. 1992), rev'd, 49 F.3d 807, 813 (1st Cir. 1995).

105. Lotus Dev. Corp. v. Borland Int'l, Inc., 49 F.3d 807, 813 (1st Cir. 1995), aff'd by equally divided Court, 516 U.S. 233 (1996). 
protection set forth in 17 U.S.C. $\int 102(b)$. The court held the Lotus menu command hierarchy is an uncopyrightable "method of operation."

The Lotus menu command hierarchy provides the means by which users control and operate Lotus 1-2-3. If users wish to copy material, for example, they use the "Copy" command. If users wish to print material, they use the "Print" command. Users must use the command terms to tell the computer what to do. Without the menu command hierarchy, users would not be able to access and control, or indeed make use of, Lotus 1-2-3's functional capabilities.

The Lotus menu command hierarchy does not merely explain and present Lotus 1-2-3's functional capabilities to the user; it also serves as the method by which the program is operated and controlled. ${ }^{106}$

The U.S. Supreme Court affirmed without opinion by an equally divided vote. $^{107}$

Subsequent appellate decisions reached similar outcomes, although they did not fully adopt the First Circuit's categorical exclusion of menu command hierarchies from copyright protection. In MiTek Holdings, Inc. v. ARCE Engineering Co., ${ }^{108}$ the holder of a copyright in an application program that designed and arranged wood trusses for the framing of building roofs brought an infringement action against the maker of a competing program that featured a similar menu command tree and user interface. Affirming the lower court's decision, the Eleventh Circuit held that the menu and submenu command structure of the truss design program was uncopyrightable under $\int 102(\mathrm{~b})$ of the Copyright Act because it represents a process. ${ }^{109}$ The court did not need to reach the broader question, addressed in Lotus, of whether all menu command structures are uncopyrightable as a matter of law. ${ }^{110}$

In Mitel, Inc. v. Iqtel, Inc., ${ }^{111}$ Mitel, the maker of a widely-adopted computer system for automating the selection of a particular telephone long distance carrier and remotely activating optional telecommunications features such as speed dialing, sued Iqtel, a competing firm that used the identical command codes for copyright infringement. Because Mitel's system had become a de facto standard, Iqtel defended its use of compatible controller codes on the ground that "technicians who install call controllers would be unwilling to

\footnotetext{
106. Lotus, 49 F.3d at 815.

107. See Lotus Dev. Corp. v. Borland Int'l, Inc., 516 U.S. 233 (1996).

108. 89 F.3d 1548 (11th Cir. 1996).

109. See id. at 1556-57.

110. See id. at 1557.

111. 124 F.3d 1366 (10th Cir. 1997).
} 
learn Iqtel's new set of instructions in addition to the Mitel command code set, and the technicians' employers would be unwilling to bear the cost of additional training." 112

As Borland had done, Iqtel's product included both its own set of command codes as well as a "Mitel Translation Mode." "While commenting that a method of operation may in some circumstances contain copyrightable expression, the Tenth Circuit nonetheless concluded that the Mitel command codes, which were arbitrarily assigned, lacked the minimal degree of creativity necessary to qualify for copyright protection. ${ }^{114}$ The court further held that Mitel's command codes should be denied copyright protection under the scènes à faire doctrine because external factors, such as compatibility requirements and industry practices, largely dictated the codes. ${ }^{115}$

There were no further cases reported addressing copyright protection for APIs over the next fifteen years. We address the Federal Circuit's decision upholding copyright protection for APIs in the Oracle v. Google case in Section V.B.5.

b) Permissibility of Reverse Engineering

As discussed in Section V.A, network system developers can use encryption and trade secret law to protect computer code. ${ }^{116}$ Distributing computer programs in object code (binary) format typically constitutes a reasonable effort to maintain secrecy. As noted, however, competitors can lawfully gain access to such information through reverse engineering. One such method is to experiment with object code to determine which bits are necessary for interoperability. Such forensic work typically requires the investigator to make many copies, raising the risk of copyright infringement.

The LaST Frontier Final Report, a consensus statement of leading intellectual property scholars, opined that "limited copying of programs for the purpose of examination and study ... falls within the rigorous terms of the fair use provisions in section 107 of the Copyright Act." 117 In addition to holding that computer code necessary for interoperability is unprotectable under $\int 102(\mathrm{~b})$, the Ninth Circuit's Sega decision authorized the copying of

112. Id. at 1369.

113. See id. at 1368-70.

114. See id. at 1372-74.

115. See id. at 1374-76.

116. See supra Section V.A.

117. See Chisum et al., supra note 59, at 25; see also Samuelson \& Scotchmer, supra note 59, at 1650 . 
entire computer programs for purposes of deciphering unprotectable code elements. ${ }^{118}$ In explaining why disassembly and reproduction of object code constitute fair use, the court reasoned that the "functional requirements for compatibility" with a computer program are unprotectable by copyright. ${ }^{119}$ The Ninth Circuit based its analysis on the architecture of the intellectual property system:

[D]isassembly of the object code in Sega's video game cartridges was necessary in order to understand the functional requirements for Genesis compatibility. The interface procedures for the Genesis console are distributed for public use only in object code form, and are not visible to the user during operation of the video game program. Because object code cannot be read by humans, it must be disassembled, either by hand or by machine ... If disassembly of copyrighted object code is per se an unfair use, the owner of the copyright gains a de facto monopoly over the functional aspects of his work-aspects that were expressly denied copyright protection by Congress. 17 U.S.C. $\int 102(b)$. In order to enjoy a lawful monopoly over the idea or functional principle underlying a work, the creator of the work must satisfy the more stringent standards imposed by the patent laws. Bonito Boats, Inc. v. Thunder Craft Boats, Inc., 489 U.S. 141, 159-64 (1989). Sega does not hold a patent on the Genesis console. ${ }^{120}$

The Ninth Circuit reaffirmed and expanded the Sega analysis in Sony Computer Entertainment, Inc. v. Connectix Corp. ${ }^{121}$

\section{Software Licensing}

Copyright law grants authors exclusive rights to copy, adapt, distribute, publicly perform, and publicly display protected works, subject to various limitations. The early computer industry, however, did not rely on proprietary control over their customers' use or adaptation of their software programs. Nor did companies restrict customers' access to source code. Rather, the industry - led by IBM and followed by Burroughs, UNIVAC, NCR, Control Data, General Electric, and RCA (often referred to as the "Seven Dwarfs" due to IBM's dominance in the computer industry) — bundled software with their

118. See Sega Enters. Ltd. v. Accolade, Inc., 977 F.2d 1510, 1520-27 (9th Cir. 1993); Menell, supra note 16, at 332-34.

119. See id. at 1522 (citing 17 U.S.C. \ 102(b)).

120. Sega Enters. Ltd. v. Accolade, Inc., 977 F.2d 1510, 1526 (9th Cir. 1993).

121. 203 F.3d 596 (9th Cir. 2000). The Sony case held that the fair use defense applied even in a case that allowed consumers to bypass purchasing the Sony PlayStation. In Sega, the reverse engineered products produced by Accolade could only be run on the Sega Genesis console. 
mainframes and derived revenues from leasing computer usage and sales of complementary products and services. ${ }^{122}$ In this era, IBM actively facilitated sharing of software among its users as a way of increasing usage of its computers.

The structure of the computer industry and copyright's role dramatically changed during the 1970s. With technological advances creating a minicomputer market and IBM's 1969 decision to unbundle software from mainframe leasing in the face of antitrust charges, computer hardware vendors and independent software developers came to use copyright licenses to protect computer programs. The opening of a competitive proprietary software marketplace ended an era in which software was freely shared. ${ }^{123}$

This shift produced a backlash within the programmer community that continues to reverberate throughout the computer hardware and software industries. The rapid rise of a robust microcomputer industry followed by the creation of the Internet generated a robust, independent software marketplace. These technologies had strong and complex network effects, which have been substantially affected by software licensing practices. While many hardware and software enterprises continue to rely heavily on proprietary software licensing agreements, the programmers' backlash against restrictive software licensing as well as business strategies aimed at disrupting proprietary standards have dramatically reshaped software licensing institutions, practices, and patterns.

This Section explores this evolving landscape. Section a) traces the emergence of the free software movement, which resourcefully uses copyright licensing to promote open platforms. The movement's innovative licensing framework produced a form of network effects. Section b) examines the open source movement, based on a more permissive licensing model, which broadened the shift away from proprietary software licensing. Section c) discusses the use of dedication of software copyrights to the public domain as a third alternative for promoting network effects. Section d) surveys federal copyright preemption of licensing restrictions.

a) The Free Software Movement (General Public License)

Many independent and academic programmers, who had long enjoyed free access to source code, viewed the shift to proprietary software licensing as a debilitating restriction on collaborative research, programming freedom, and software innovation. Beginning in the early 1980s, Richard Stallman, then a

122. See Paul E. Ceruzzi, A History of Modern Computing ch. 5 (2d ed. 2003).

123. See Douglas E. Phillips, The Software License Unveiled: How Legislation By LiCEnSE Controls SOFTWARE ACCESS 113-15 (2009). 
researcher in MIT"s Artificial Intelligence Laboratory, began a grass-roots "free software" movement. Although Stallman was vehemently opposed to intellectual property protection for computer software, he came to see that the same copyright protections that exclude competitors could be deployed to prohibit restrictions on adaptation and reuse of code and to foster open platforms. $^{124}$

Stallman established the Free Software Foundation (FSF) in 1985 to promote users' rights to use, study, copy, modify, and redistribute computer programs. The FSF devised the General Public License (GPL) to prevent programmers from building proprietary limitations into software. The GPL guarantees end users the freedoms to run, study, share (copy), and modify the software so long as the users permit use of any derivative works on the same terms. ${ }^{125}$ In this way, GPL software "infects" derivative works with user rights and virally spreads these rights through the collaborative software ecosystem.

Stallman targeted the development of a viable UNIX-compatible open source operating as FSF's initial goal. ${ }^{126}$ The UNIX operating system, developed by researchers at MIT, AT\&T's Bell Labs, and General Electric in the late 1960s and early 1970s offered innovative time-sharing capability. ${ }^{127} \mathrm{It}$ became a foundation for modern computer operating system design. ${ }^{128}$ In 1972, two Bell Labs researchers-Dennis Ritchie, inventor of the C programming language, and Ken Thompson-rewrote UNIX in C, enabling UNIX to be installed on any advanced computer system. AT\&T held the copyright to UNIX, which restricted its use and adaptation. Stallman sought to liberate UNIX through the GNU ("GNU's Not Unix") GPL independent re-implementation project.

Many programmers throughout the world contributed to this effort on a voluntary basis, and by the late 1980s most of the components had been assembled. The project reached fruition in 1991 when Linus Torvalds developed a UNIX-compatible kernel-the central core of the operating

124. See SteVen Weber, The Success of Open Source 47-49 (2004).

125. See Carver, supra note 15, at 443-44.

126. See Initial Announcement, GNU Operating Sys. (Sept. 7, 1983), https://www.gnu.org/gnu/initial-announcement.en.html [https://perma.cc/B4X8-UNCP]; Richard Stallman, The GNU Manifesto, 10 Dr. DOBB's J. SOFTWARE TOOLS 30 (1985); GNU Manifesto, WIKIPEDIA, https://en.wikipedia.org/wiki/GNU_Manifesto[https://perma.cc/ EF6V-GB84].

127. See Unix, WIKIPEDIA, https://en.wikipedia.org/wiki/Unix [https://perma.cc/ W7AG-GHKQ].

128. Marshall Kirk McKusick, Twenty Years of Berkeley Unix: From AT\&WT Owned to Freely Redistributable, in OPEN SOURCES: VOICES FROM THE OPEN SOURCE REVOLUTION 31 (Chris DiBona, Sam Ockman \& Mark Stone eds., 1999). 
system. ${ }^{129}$ Torvalds structured the evolution of his component on the GPL model. The resulting UNIX-compatible free software program, dubbed "Linux," has become widely used throughout the computing world. ${ }^{130}$

While attractive to many independent, non-commercial programmers, the so-called "copyleft" GPL licensing model posed a serious problem for many commercial software vendors. Although it afforded free access to GPL software, it prevented these cumulative developers from charging a royalty for their modifications and subjected further modifications by licensees to GPL restrictions. ${ }^{131}$

b) The Open Software Movement (Permissive Licenses)

The "open source" movement emerged as a middle ground between proprietary software distribution and the "free" software movement. Like Linux, the open source movement traces its roots to efforts to liberate UNIX. In the mid-1970s, Ken Thompson at the University of California, Berkeley, spearheaded an effort by Berkeley faculty and students to enhance UNIX capabilities. ${ }^{132}$ In contrast to the GPL, the Berkeley Software Development (BSD) project offered its software on a "permissive" basis: licensees could distribute modifications of the BSD software whether or not the modifications were freely licensed. ${ }^{133}$ Nonetheless, the licensee was still obliged to obtain a license from AT\&T for the underlying UNIX code. ${ }^{134}$

As the Internet took off in the late 1990s, a growing number of hardware and software vendors embraced "free" and "open source" development and distribution strategies. They saw these non- or less-proprietary licensing models as means to prevent Microsoft from expanding its influence into the Internet and other platform technologies while simultaneously promoting competition and innovation. ${ }^{135}$ There is now a wide variety of permissive open

129. See Linux, WikIPEDIA, https://en.wikipedia.org/wiki/Linux [https://perma.cc/ VQL2-S4D8].

130. See id.

131. See Lothar Determann, Dangerous Liaisons-Software Combinations as Derivative Works? Distribution, Installation, and Execution of Linked Programs under Copyright Law, Commercial Licenses, and the GPL, 21 BERKELEY TECH. L.J. 1421, 1484 (2006).

132. See Berkeley Software Distribution, WIKIPEDIA, https://en.wikipedia.org/wiki/ Berkeley_Software_Distribution [https://perma.cc/SV4M-N9KN].

133. See BSD Licenses, WIKIPEDIA, https://en.wikipedia.org/wiki/BSD Licenses [https://en.wikipedia.org/wiki/BSD Licenses].

134. See id.

135. See, e.g., Josh Lerner \& Jean Tirole, The Economics of Technology Sharing: Open Source and Beyond, 19 J. ECON. PERsP. 99, 106 (2005); Merges, supra note 39, at 191-93; Yochai Benkler, Coase's Penguin, or, Linux and the Nature of the Firm, 112 YALE L.J. 369, 445 (2002); Yochai 
source licensing models. ${ }^{136}$ Free (GPL) and open source software play strong and increasing roles in network technologies, such as operating systems (e.g., Linux), Internet infrastructure (e.g., Apache Web Server), and mobile devices (e.g., Android), but have been less successful in penetrating consumer as opposed to programmer-centric product areas. ${ }^{137}$ Notwithstanding the proliferation of free and open source licenses, there have been relatively few litigated disputes. ${ }^{138}$

c) Dedication to the Public Domain

A further distribution alternative that has been especially important in the proliferation of network benefits is outright dedication of computer software copyrights (and other forms of intellectual property) to the public domain. Tim Berners-Lee, the developer of the World Wide Web (WWW), was initially attracted to releasing his hypertext software platform under the GPL. ${ }^{139}$ Internet engineers, however, raised the concern that any restrictions attached to its usage could limit its adoption and use. Some large companies were rumored to be opposed to allowing usage of any software that could trigger license restrictions, including GPL copyleft requirements. Berners-Lee ultimately chose to dedicate the WWW to the public domain. Notwithstanding concerns that unprotected software could be fragmented and captured through proprietary extensions, the WWW has thrived and remained remarkably stable. ${ }^{40}$ This is attributable to the very strong network effects of Internet protocols and the community and technically driven, open, standardsetting processes administered by the WWW Consortium (W3C) headed by Berners-Lee and the Internet Engineering Task Force (IETF).

\section{d) Federal Preemption of Contractual Restrictions}

In contrast to the free and open software movements, some software developers use licensing provisions to restrict use of their copyrighted software. Some licenses, for example, bar reverse engineering of software programs. Such a restriction affords the copyright owner greater control over

Benkler, Sharing Nicely: On Shareable Goods and the Emergence of Sharing as a Modality of Economic Production, 114 YALE L.J. 273, 289-91 (2004); see generally David McGowan, Innovation, Uncertainty, and Stability in Antitrust Law, 16 BERKELEY TECH. L.J. 729 (2001).

136. MEEKER, supra note 12, at 287-94 (Appendix B).

137. PhiLlips, supra note 123, at 156, 158-68; see also Josh Lerner \& Jean Tirole, The Economics of Technology Sharing: Open Source and Beyond, 19 J. ECON. PERSP. 99, 107 (2005).

138. See Jacobsen v. Katzer, 535 F.3d 1373 (Fed. Cir. 2008); PHILLIPS, supra note 123, at 120-21 (2009).

139. Tim Berners-Lee, Weaving The Web: The Original Design And Ultimate DESTINY OF THE WORLD WIDE WEB 72-73 (2000).

140. See PHILlips, supra note 123 , at 174. 
the development of interoperable products. The courts are divided, however, over whether federal copyright law and intellectual property policies preempt such state law, contractual provisions.

In Vault Corp. v. Quaid Software, Ltd., ${ }^{141}$ the Fifth Circuit Court of Appeals held that the Louisiana Software License Enforcement Act clause permitting a copyright owner to prohibit software decompilation or disassembly was preempted by the Copyright Act, and therefore unenforceable. A more recent case interpreted the scope of federal copyright protection more narrowly, enforcing licensing restrictions that bar activities that would otherwise fall within copyright's fair use privilege. ${ }^{142}$ The dissenting opinion in that case, however, indicates that the scope of federal preemption of licensing restrictions that contract around the fair use privilege remains unsettled. ${ }^{143}$ Section VI examines the related questions of whether antitrust law or misuse doctrines further restrict licensing provisions that leverage intellectual property rights to hinder downstream innovation or competition.

\section{Interoperability Exception to the DMCA's Anti-Circumvention Probibition}

The permissibility of reverse engineering software to achieve interoperability arose during the legislative deliberations over the enactment of anti-circumvention prohibitions. With the emergence of the Internet in the mid-1990s, motion picture studios, record labels, publishers, and other content owners came to see encryption and other digital rights management technologies as a promising self-help means to discourage unauthorized distribution of their works. They recognized, however, that such technologies would be vulnerable to unauthorized circumvention of technological protection measures. Thus, they sought to expand copyright protection beyond its traditional prohibitions against infringement to include limits on the decrypting or circumventing of technological protection systems and the trafficking in such decryption tools. They contended that without such protection, they would be unwilling to release content onto the Internet, which in turn would hamper the adoption of broadband services. Various other interests-ranging from consumer electronics manufacturers, library associations, computer scientists, and law professors-expressed concern about potential chilling effects of such an expansion of copyright law upon those who wish to make fair use of copyrighted works.

141. 847 F.2d 255 (5th Cir. 1988).

142. See Bowers v. Baystate Techs., 320 F.3d 1317 (Fed. Cir. 2003).

143. JONATHAN BAND \& MASANOBU KATOH, INTERFACES ON TRIAL 2.0 121-33 (2011). 
Congress crafted a compromise in the Digital Millennium Copyright Act of 1998 (DMCA). ${ }^{144}$ Section 1201(a) bans circumvention of technological protection measures put in place by copyright owners to protect copyrighted works. Section (b) prohibits trafficking in anti-circumvention tools. Section 1201(f)(1) provides that

a person who has lawfully obtained the right to use a copy of a computer program may circumvent a technological measure that effectively controls access to a particular portion of that program for the sole purpose of identifying and analyzing those elements of the program that are necessary to achieve interoperability of an independently created computer program with other programs, and that have not previously been readily available to the person engaging in the circumvention, to the extent any such acts of identification and analysis do not constitute infringement under this title.

The legislative history notes that this provision is

intended to allow legitimate software developers to continue engaging in certain activities for the purpose of achieving interoperability to the extent permitted by law prior to the enactment of this chapter. The objective is to ensure that the effect of current case law interpreting the Copyright Act is not changed by enactment of this legislation for certain acts of identification and analysis done in respect of computer programs. See Sega Enterprises Ltd. v Accolade, Inc., 977 F.2d 1510, 24 U.S.P.Q.2d 1561 (9th Cir. 1992). The purpose of this section is to foster competition and innovation in the computer and software industry. ${ }^{145}$

Because violations of the DMCA are not acts of copyright infringement, but rather separate offenses, courts have held that the defenses available under the Copyright Act, including fair use, do not apply to anti-circumvention violations. ${ }^{146}$ While $\int 1201(\mathrm{c})(1)$ provides that "nothing in this law" shall interfere with "fair use" among other defenses, the courts have reasoned that the DMCA does not interfere with fair use but merely renders it irrelevant by allowing copyright owners to bring a non-copyright claim. Furthermore, the larger structure of the DMCA provides additional safeguards to address free expression and other concerns.

144. 17 U.S.C. \1201 (2018) (Circumvention of copyright protection systems).

145. S. REP. NO. 105-190, at 13 (1998).

146. See Universal City Studios, Inc. v. Corley, 273 F.3d 429 (2d Cir. 2001); 321 Studios v. MGM Studios, Inc., 307 F. Supp. 2d 1085 (N.D. Cal. 2004). 
Beyond the statutory exemptions to the anti-circumvention ban, the DMCA established a triennial rulemaking process for exempting particular categories of works from the anti-circumvention ban for which "noninfringing uses by persons who are users of a copyrighted work are, or are likely to be, adversely affected." "147 Several of the granted exemptions authorize decryption for purposes of developing interoperable products.

Smartphones, tablets, other mobile computing devices, and smart TVs, all of which have networking aspects, have attracted particular attention. Several major manufacturers of these products have sought to use encryption technologies to bundle the devices in telecommunications service plans. In a series of rulemaking proceedings, the Copyright Office has exempted unlocking or "jailbreaking" of these products from the anti-circumvention ban. ${ }^{148}$ Congress and the FCC have reinforced, extended, and expanded these exemptions. ${ }^{149}$

The DMCA's anti-circumvention provisions have generated several cases involving the use of technological protection measures to exclude competitors from aftermarkets - goods or services supplied for a durable product after its initial sale (e.g., replacement ink for printers). Several companies embedded digital code into their products and aftermarket components that must interoperate to function as a means of exerting control over such aftermarkets. When competitors in these aftermarkets decrypted such digital codes to manufacture their own components, these durable product manufacturers sued, alleging violation of the anticircumvention provisions of the DMCA. Some courts have declined to find liability, emphasizing that the careful balance that Congress sought to achieve between the interests of content creators and information users would be upset if the anti-circumvention prohibitions could be applied to activities that did not facilitate copyright infringement. ${ }^{150}$

147. 17 U.S.C. $\int 1201(\mathrm{a})(1)(\mathrm{B})-(\mathrm{D})$.

148. See Library of Congress, U.S. Copyright Office, Exemption to Prohibition on Circumvention of Copyright Protection Systems for Access Control Technologies, 83 Fed. Reg. 54010 (Oct. 26, 2018).

149. See Unlocking Consumer Choice and Wireless Competition Act, Pub. L. No. 113144, 128 Stat. 1751 (2014); see generally JONATHAN BAND, INTERFACES ON TRIAL 3.0: ORACLE AMERICA V. GOOGLE AND BEYOND 79-109 (2018) (unpublished manuscript), https://ssrn.com/abstract=2876853 [https://perma.cc/NKH6-KW4S].

150. See Chamberlain Group, Inc. v. Skylink Techs., Inc., 381 F.3d 1178, 1202 (Fed. Cir. 2004) (holding that section 1201 "prohibits only forms of access that bear a reasonable relationship to the protections that the Copyright Act otherwise affords copyright owners"); Lexmark Int'l, Inc. v. Static Control Components, Inc., 387 F.3d 522 (6th Cir. 2005) (holding 
a) GPL 3.0 - DRM Provision

To bar intellectual property restrictions on software use and promote sharing of code, the Free Software Foundation added a provision to the General Public License 3.0 (released in 2007) barring licensors and those who use the licensed code from enforcing anti-circumvention prohibitions. ${ }^{151} \mathrm{GPL}$ 3.0 has not been as widely adopted as prior GPL versions, particularly among commercial enterprises. ${ }^{152}$

\section{Software Copyright Jurisprudence: The Oracle v. Google Litigation}

After the Lotus $v$. Borland case resolved, litigation subsided over copyright protection for the functional specifications of APIs and other network features of computer software. ${ }^{153}$ The Sega, Altai, and Borland decisions and software industry norms accorded competitors the ability to develop interoperable code and devices so long as they independently implemented the functional specifications of the target platform. ${ }^{154}$ If the programs were encrypted or only released in object code form, the competitor would need to reverse engineer the code, which could be costly and time-consuming. Beyond the drudgery of reverse engineering, copyright did not stand in the way of developing and distributing interoperable code and devices.

A shift in business strategy in the Internet Age reinforced these legal principles and industry norms. Whereas most software vendors in the preInternet era sought to appropriate a return on their investments directly through software and device sales and licenses, the Internet expanded the potential for multi-sided markets and indirect appropriability-principally through advertising, service plans, and use of customer data. ${ }^{155}$ These strategies harnessed the positive feedback effects of network technologies.

that the lock-out technology at issue did not effectively control access to a copyrighted work); Storage Tech. Corp. v. Custom Hardware Eng'g \& Consulting, Inc., 421 F.3d 1307 (Fed. Cir. 2005) (holding that decryption by a third party software repair entity to perform software maintenance activities is not actionable); but see MDY Indus., LLC v. Blizzard Entm't, Inc., 629 F.3d 928, 948-52 (9th Cir. 2010) (declining to adopt an infringement nexus requirement).

151. GNU General Public License: Version 3, FreE SofTwARE Found. (June 29, 2007), https://www.gnu.org/licenses/gpl-3.0.en.html [https://perma.cc/5F26-E34R] [hereinafter GNU General Public License].

152. See infra Section V.D.3.c); see generally MEEKER, supra note 12, at ch. 10.

153. See Menell, supra note 70, at 709-10.

154. See Menell, supra note 16, at 448-49.

155. See Martin Campbell-Kelly et al., Economic and Business Perspectives on Smartphones as Multi-Sided Platforms, 39 TELECOMM. POL'Y 717, 730-32 (2015); see generally David S. Evans, Antitrust Economics of Multi-Sided Platform Markets, 20 YALE J. ON REG. 325 (2003); SHAPIRO \& VARIAN, supra note 5. 
Beginning with Netscape, a growing number of Internet Age entrepreneurs valued adoptions over revenues in the start-up phase of their enterprises. The Internet provided a low-cost means of distributing information and software, goods that had zero marginal reproduction cost. For example, Sun Microsystems released the Java programming language to the public as a means of promoting its hardware sales and forestalling Microsoft's dominance of website development tools. ${ }^{156}$ Google developed a robust revenue stream for its search technologies without ever charging users. It profited handsomely from bundling search results with keyword-generated advertisements.

Thus, many software and Internet companies welcomed adoption of their platforms, including interoperability with their APIs. Sun Microsystems dedicated the Java programing language to the public domain early on, and in 2006 licensed the Java Standard Edition, Enterprise Edition, and Micro Edition platforms - comprising packages of pre-written APIs-under the GPL. Unlike Sega, it published its API specifications for the world to see, adopt, and emulate. Its primary concern was maintaining the Write Once, Run Anywhere (WORA) interoperability of these platforms. Hence, it required licensees to verify that implementations satisfied the particular Java Technology Compatibility Kit (TCK) test.

When Google ventured into mobile platform development, it sought to take advantage of the millions of programmers intimately familiar with Java, the most widely used programming language and platform for web development. But unlike Borland, which sought to achieve perfect interoperability with the Lotus 1-2-3 menu command hierarchy so that Lotus macros could run on Borland's Quattro system, Google sought to customize Java for the smaller chip size of mobile handsets and add additional features, such as location tools and a camera. Consequently, Google did not plan to include all the Java APIs, which meant that the resulting system would not pass the Java TCK test. Moreover, Google and its open handset alliance partners did not believe that the GPL would provide sufficient flexibility for the range of players it believed would be needed to establish a robust new mobile platform. They worried that the viral share and share alike provision would discourage Google's handset manufacturer and telecommunications partners from investing in innovative features. The members of the Android Open Handset Alliance believed that a more permissive licensing model, in which

156. See Menell, supra note 16 , at 350-51. 
downstream suppliers could make proprietary extensions on top of the base platform, would better promote robust competition and innovation. ${ }^{157}$

When licensing negotiations between Google and Sun reached an impasse, Google chose to re-implement a subset of Java API packages independently to take advantage of the vast Java programming community and the decade of testing that the Java APIs had undergone. Google did not need to reverse engineer the Java API functional specifications because Sun disclosed them. Nonetheless, Google had to devote substantial resources to re-implementing the code using a clean room process.

When Google introduced Android in late 2007, Sun's CEO publicly praised the adoption of Java. Privately, however, he and other Sun leaders seethed at Google's cavalier approach and forking of the Java platform. Nonetheless, Sun refrained from blocking Android through legal action. ${ }^{158}$

With its hardware business in decline and unable to monetize Java, Sun's viability as an independent company came into question. Oracle Corporation, which had built many of its software products on the Java platform, acquired Sun in 2010. Oracle immediately pressured Google to license Java and when Google declined, Oracle sued alleging that Android infringed Java-related patents and copyrights. Oracle focused its copyright claim on Google's copying of function labels, functional specifications (declarations), and the structure, sequence, and organization of 37 Java API packages.

After the jury rejected Oracle's patent causes of action, the district court ruled that the Java APIs were not copyrightable. ${ }^{159}$ Judge Alsup cautioned that the ruling did not hold "Java API packages are free for all to use without license" or that "the structure, sequence and organization of all computer programs may be stolen." ${ }^{\text {"160 }}$ He grounded his decision in the particular and distinctive functional attributes of the 37 Java APIs and that Google independently wrote its own implementing code using a clean room process. ${ }^{161}$ The principal copying concerned the lines of declarations, which are necessary to operate the particular methods of the APIs. As Judge Alsup explained:

Significantly, the rules of Java dictate the precise form of certain necessary lines of code called declarations, whose precise and necessary form explains why Android and Java must be identical when it comes to those particular lines of code. That is, since there is only

157. See Menell, supra note 16, at 359-72.

158. Id. at 369 .

159. See Oracle Am., Inc. v. Google Inc., 872 F. Supp. 2 d 974 (N.D. Cal. 2012).

160. Id. at 1002 .

161. See id. 
one way to declare a given method functionality, everyone using that function must write that specific line of code in the same way. ${ }^{162}$

While acknowledging that the overall structure of the Java API packages is creative, original, and "resembles a taxonomy," Judge Alsup nonetheless concluded that it functions as "a command structure, a system or method of operation — a long hierarchy of over six thousand commands to carry out preassigned functions." 163 Applying copyright's limiting doctrines as the Ninth Circuit has interpreted them, emphasizing the Sega decision, and following CONTU's guidance that when specific computer instructions, "even though previously copyrighted, are the only and essential means of accomplishing a given task, their later use by another will not amount to an infringement," 164 Judge Alsup determined that Google was free to write code that accomplished the same functionality as the Java APIs at issue even if it did not achieve complete compatibility with the full Java platform. Later developers can achieve the particular functionality or method of operation of an API subsystem (and even groups of subsystems) so long as they write their own code and no patent protects that method.

Oracle appealed the copyright issues to the U.S. Court of Appeals for the Federal Circuit. ${ }^{165}$ The Federal Circuit is bound by regional circuit law when reviewing questions that involve law and precedent not exclusively assigned to the Federal Circuit.

Notwithstanding the Ninth Circuit's holding in Sega and Sony Computer Entertainment, Inc. v. Connectix Corp. that copyright law does not prohibit the precise coding necessary to achieve interoperability, ${ }^{166}$ the Federal Circuit reversed the district court's determination that the structure, sequence, and organization of the 37 Java APIs were not copyrightable. ${ }^{167}$ The appellate court determined that even high-level API design choices-including function

162. Id. at 979 (emphasis in original).

163. Id. at $999-1000$.

164. Id. at 986 (quoting CONTU REPORT, supra note 66, at 20) (emphasis added by Judge Alsup).

165. See generally Peter S. Menell, API Copyrightability Bleak. House: Unraveling and Repairing the Oracle v. Google Jurisdictional Mess, 31 BERKELEY TECH. L.J. 1515, 1581-83 (2016) (explaining and questioning the Federal Circuit's jurisdiction over appeals from district court cases involving patent infringement allegations even if neither party challenges the district court's patent rulings).

166. Sega Enters. v. Accolade, Inc., 977 F.2d 1510, 1525 (9th Cir. 1993); Sony Comput. Entm't., Inc., v. Connectix Corp., 203 F.3d 596, 603 (9th Cir. 2000) (“There is no question that the Sony BIOS contains unprotected functional elements.").

167. See Oracle Am., Inc. v. Google, Inc., 750 F.3d 1339 (Fed. Cir. 2014); Menell, supra note 16 , at 388 . 
labeling choices and compilation of functions - satisfy copyright law's low originality threshold. ${ }^{168}$ The court side-stepped the Sega and Sony cases by construing Ninth Circuit law to hold that "copyrightability is focused on the choices available to the plaintiff at the time the computer program was created," not the defendant's desire to achieve interoperability. ${ }^{169}$ The court concluded that Google's interoperability argument comes into play only as part of a fair use defense, an issue on which the jury had hung. ${ }^{170}$ Consequently, the court remanded the case for a fair use trial. ${ }^{171}$

On remand, the jury concluded that Android's use of Java API declarations and structure, sequence, and organization constituted fair use. The Federal Circuit once again reversed, holding that the fair use balance tilted in Oracle's favor. ${ }^{172}$ The Federal Circuit's decision gives no weight to the second fair use factor based on a questionable reading of Ninth Circuit jurisprudence. ${ }^{173}$

The Federal Circuit's decision rejecting Judge Alsup's API copyrightability ruling is the most significant recent federal appellate decision to confront the copyrightability of APIs. Given the proliferation of software patents, there is a high likelihood that a company with a widely-used set of APIs would be able to pursue both patent and copyright causes of action in the same litigation, thereby bringing the Federal Circuit's exclusive jurisdiction over patent cases

168. See Oracle, 750 F.3d at 1354, 1356-57.

169. See id. at 1370-71.

170. See id. at 1358 (citing Ets-Hokin v. Skyy Spirits, Inc., 225 F.3d 1068, 1082 (9th Cir. 2000)); Satava v. Lowry, 323 F.3d 805, 810 n.3 (9th Cir. 2003) ("The Ninth Circuit treats scènes à faire as a defense to infringement rather than as a barrier to copyrightability.").

171. See id. at 1372-74.

172. See Oracle America, Inc. v. Google LLC, 886 F.3d 1179 (Fed. Cir. 2018).

173. See id. at 1205 (explaining that:

[t]he Ninth Circuit has recognized ... that th[e] second factor 'typically has not been terribly significant in the overall fair use balancing.' Dr. Seuss Enters., L.P. v. Penguin Books USA, Inc., 109 F.3d 1394, 1402 (9th Cir. 1997) (finding that the 'creativity, imagination and originality embodied in The Cat in the Hat and its central character tilts the scale against fair use'); Mattel[, Inc. v. Walking Mountain Prods., 353 F.3d 792, 803 (9th Cir. 2003)] (similar).

The Federal Circuit's reliance on Dr. Seuss Enters. and Mattel is misplaced. Those cases addressed familiar children's stories and dolls; neither involved functional works, let alone computer software. By contrast, the Ninth Circuit's decisions in Sega, 977 F.2d at 1524-27 (9th (extensive discussion of the second factor connecting fair use to Baker $v$. Selden and $\$ 102(\mathrm{~b})$ ) and Sony Comput. Entm't, 203 F.3d at 602-05 (leading its discussion of fair use with the second fair use factor and affording it great significance), provide a far sounder footing for analyzing fair use in Oracle v. Google. 
into play. ${ }^{174}$ Google is seeking Supreme Court review of both the Federal Circuit's 2014 API copyrightability decision and its 2018 fair use decision. ${ }^{175}$

\section{Standards and Codes}

Copyright protection extends to any work of authorship fixed in a tangible medium of expression, subject to various limiting doctrines, such as the ideaexpression dichotomy and fair use. Standard setting bodies generally promote access to their standards and codes. Sun (and later Oracle) published the Java API declarations. Their members typically wish to encourage widespread adoption of sponsored standards.

Some developers of standards seek to control access to their specifications. As reflected in the Sega case, Sega controlled the access codes for the Genesis game platform through trade secret law. ${ }^{176}$ After Accolade successfully reversed engineered the interoperability code, Sega sought to bar its use by Accolade (and recover for copyright infringement). The Ninth Circuit held, however, that software code elements necessary for interoperability are unprotectable by copyright law. ${ }^{177}$

174. See Menell, supra note 165 , at 1518.

175. See Google LLC v. Oracle America, Inc., U.S. Supreme Court No. 18-956, Petition for a Writ of Certiorari to the United States Court of Appeals for the Federal Circuit (Jan. 2019).

176. See Sega Enters. v. Accolade, Inc., 977 F.2d 1510, 1532 (9th Cir. 1993).

177. See id. at 1514 (referring to "unprotected functional elements of the program"); 1517 (referring to "functional requirements for Genesis compatibility"); 1522 (referring to "functional requirements for Genesis compatibility"); 1523 (noting that

Accolade's identification of the functional requirements for Genesis compatibility has led to an increase in the number of independently designed video game programs offered for use with the Genesis console. It is precisely this growth in creative expression, based on the dissemination of other creative works and the unprotected ideas contained in those works, that the Copyright Act was intended to promote)

(citing Feist Publications, Inc. v. Rural Tel. Serv. Co., 499 U.S. 340 (1991) (citing Harper \& Row, 471 U.S. at 556-57)); 1524 (noting that "[i]n some circumstances, even the exact set of commands used by the programmer is deemed functional rather than creative for purposes of copyright. '[W] hen specific instructions, even though previously copyrighted, are the only and essential means of accomplishing a given task, their later use by another will not amount to infringement." " (quoting CONTU REPORT, supra note 66, at 20)); 1525 (observing that

$[\mathrm{u}]$ nder a test that breaks down a computer program into its component subroutines and sub-subroutines and then identifies the idea or core functional element of each, such as the test recently adopted by the Second Circuit in [Computer Associates v. Altai], many aspects of the program are not protected by copyright. In our view, in light of the essentially utilitarian 
Various technical, building, and other standards development seek to control access to their work product principally to earn publication royalties. They contend that the royalty income provides vital funding for coordinating standard development, resulting in better formulated and maintained codes. ${ }^{178}$

Scholars have questioned the need for copyright protection to promote standards developments. Professor Paul Goldstein contends:

$[1 \mathrm{t}$ is difficult to imagine an area of creative endeavor in which the copyright incentive is needed less. Trade organizations have powerful reasons stemming from industry standardization, quality control and self-regulation to produce these model codes; it is unlikely that, without copyright, they will cease producing them. ${ }^{179}$

The accessibility of edicts of law raises fundamental constitutional and policy questions. ${ }^{180}$ Federal, state, and local laws, judicial opinions, and regulations incorporate these codes. The Copyright Act expressly exempts works of the federal government from copyright protection. ${ }^{181}$ Court decisions on copyrightability of non-federal edicts of law have been mixed.

The Fifth Circuit held that model codes enter the public domain when they enter into law. ${ }^{182}$ Building on that precedent, the Eleventh Circuit held that state law and the annotated compilation of such law are sufficiently law-like to

nature of computer programs, the Second Circuit's approach is an appropriate one);

1526 (referring to "functional specifications" provided to clean room programmers); 1526 (observing that

if disassembly of copyrighted object code is per se an unfair use, the owner of the copyright gains a de facto monopoly over the functional aspects of his work-aspects that were expressly denied copyright protection by Congress. 17 U.S.C. $\int 102(b)$. In order to enjoy a lawful monopoly over the idea or functional principle underlying a work, the creator of the work must satisfy the more stringent standards imposed by the patent laws)

(citing Bonito Boats, Inc. v. Thunder Craft Boats, Inc., 489 U.S. 141, 159-64 (1989)); 1527 (explaining that " $[\mathrm{u}]$ nder the Copyright Act, if a work is largely functional, it receives only weak protection .... Here, while the work may not be largely functional, it incorporates functional elements which do not merit protection").

178. Letter from Jim Shannon, President, Nat'l Fire Protection Ass'n, to Michael White, Acting Dir., Office of the Fed. Register, The Nat'l Archives and Records Admin. (June 1, 2012) (on file with the Office of the Fed. Register, Request for Comments, Federal Register, Vol. 77, no. 38, NARA 12-0002 (February 27, 2012)).

179. Paul Goldstein, Goldstein On Copyright \ 2.5 .2 (3d ed. 1996).

180. See Hearing on the Scope of Copyright Protection Before the H. Comm. on the Judiciary, 113th Cong. 84-110 (2014) (statement of Carl Malamud, President, Public.Resource.Org).

181. 17 U.S.C. $\int 105$ (2018).

182. See Veeck v. S. Bldg. Code Cong. Int'l, Inc., 293 F.3d 791 (5th Cir. 2002) (en banc). 
be regarded as sovereign work constructively authored by the citizens and thus not copyrightable. ${ }^{183}$

By contrast, the First Circuit recognized that copyright law could potentially protect building codes. ${ }^{184}$ The Ninth Circuit held that incorporation of a classification system (taxonomy) for medical procedures in Medicare and Medicaid regulations does not make them uncopyrightable. ${ }^{185}$ Nonetheless, the court held that the copyright misuse doctrine limited the ability of the AMA to enforce its copyright against a health maintenance organization that used the taxonomy to comply with federal law. ${ }^{186}$ Most recently, the D.C. Circuit overturned and remanded issuance of a permanent injunction barring a nonprofit organization from distributing copies of technical standards produced by a private organization based on copyright and trademark grounds. ${ }^{187}$ As the court noted, "[f]ederal, state, and local governments . . . have incorporated by reference thousands of these standards into law." 188 The court avoided a constitutional ruling by finding that the district court "failed to adequately consider whether, in certain circumstances, distributing copies of the law for purposes of facilitating public access could constitute transformative use." 189

\section{Trademark Protection, Unfair Competition Law, and False ADVERTISING PROTECTION}

In contrast to patent, copyright, and trade secret protection-which seek to promote innovation-trademark, unfair competition law, and false advertising protection focus primarily on ensuring the integrity of the commercial marketplace. ${ }^{190}$

The federal Lanham Act as well as analogous state statutes and common law protects words, symbols, and other attributes, such as designs, slogans, and colors, that serve to identify the source of goods or services. Certification

183. See Code Revision Comm'n v. Public.Resource.Org, Inc., 906 F.3d 1229, 1233, $1243-$ 54 (11th Cir. 2018).

184. See Bldg. Officials \& Code Admin. v. Code Tech., Inc., 628 F.2d 730, 736 (1st Cir. 1980).

185. Practice Mgmt. Info. Corp. v. Am. Med. Ass'n, 121 F.3d 516, 518-20 (9th Cir. 1997).

186. See infra Section VI.A.1.

187. See Am. Soc'y for Testing \& Materials, et al. v. Public.Resource.Org, Inc., 896 F.3d 437 (D.C. Cir. 2018).

188. See id. at 440 .

189. See id. at 450.

190. See generally Peter S. Menell, mark A. Lemley \& Robert P. Merges, Intellectual Property in the New Technological Age, Vol. II: Copyrights, Trademarks, And IP Protections, ch. V (2018); Peter S. Menell \& Suzanne Scotchmer, Intellectual Property Law, in 2 HANDBOOK OF LAW AND ECONOMICS ch. 19 (A. Mitchell Polinsky \& Steven Shavell eds., 2007). 
marks certify conformity with centralized standards. Collective marks connote that a product or service is manufactured or distributed by a member of a collective organization (e.g., Florists' Transworld Delivery Association (FTD)) or that a product or service provider is a member of a collective organization (e.g., American Automobile Association (AAA)). To receive trademark protection, a mark need not be new or previously unused, but it must represent a particular source of the good or service to consumers. It cannot merely describe the good (e.g., hotel) or represent a generic term (e.g., thermos) for the class of goods or services offered. Further, the identifying mark may not be a functional element of the product itself but must serve a purely identifying purpose. Trademarks do not expire, but continue in force unless their owner abandons them or they become generic.

Unlike patents or copyrights, trademarks do not directly protect the technology, good, or work, but rather prevent others from creating a likelihood of consumer confusion as to the source of goods. Thus, competitors may use the trademark of other companies in non-confusing ways, such as comparative advertising and descriptive usages. Furthermore, like copyright law, trademark law does not protect functional features of products. ${ }^{191}$ Patent law provides the sole means of excluding competitors from utilitarian features of products. Similarly, trademark law cannot protect aesthetically functional features of goods or packaging. Thus, trademark law does not protect a red, heart-shaped box for packaging chocolates. ${ }^{192}$ The Lanham Act and state laws prohibit false or misleading advertising.

In 1982, the Supreme Court applied the functionality doctrine in a case involving network effects. ${ }^{193}$ Ives Laboratories manufactured and marketed a patented prescription drug using distinctively colored capsules: a blue capsule for its 200-mg dosage and a combination blue-red capsule for its 400-mg dosage. ${ }^{194}$ Consumers and pharmacists came to associate the distinctive appearance of the capsules with the particular patented compound and dosages. ${ }^{195}$ Thus, a consumer could identify whether they were taking the

191. Kellogg Co. v. Nat'l Biscuit Co., 305 U.S. 111, 115, 122 (1938) (noting that the pillowshaped form of shredded wheat biscuits reduces the cost of manufacturing the biscuits and affects their quality and therefore cannot serve as trade dress).

192. RestateMENT (SECOND) OF TORTS $\int 742 \mathrm{cmt}$. a.

193. See Inwood Labs., Inc. v. Ives Labs., Inc., 456 U.S. 844 (1982).

194. See id. at 846-47.

195. As noted in the Inwood Labs decision, most States enacted laws beginning in the early 1970's allowing pharmacists to substitute generic drugs for brand name drugs under certain conditions. See id. at 847 n.4 (citing Note, Consumer Protection and Prescription Drugs: The Generic Drug Substitution Laws, 67 KY. L.J. 384 (1978-1979)). 
proper drug and dosage from its appearance. In that way, the packaging served as a simple language.

Following expiration of the utility patent, generic drug manufacturers marketed the chemical compound using the same color capsules. ${ }^{196}$ Ives sued generic drug makers for indirect trademark infringement, alleging that they bore responsibility for pharmacists that mislabeled the source of the drugs. Many pharmacies distribute capsules in pharmacist-branded bottles. ${ }^{197}$ The pharmacists violated trademark law by filling requests for Ives capsules with generic versions. ${ }^{198}$ The generic companies only bore vicarious liability for the infringing acts of pharmacists, however, if they intentionally induced pharmacists to infringe the Ives trademark or if they continued to supply its product to pharmacists that it knew were engaging in infringement. ${ }^{199}$

In finding that Ives had not proven that the generic manufacturers were indirectly liable for trademark infringement, the Supreme Court observed that "a product feature is functional if it is essential to the use or purpose of the article or if it affects the cost or quality of the article." ${ }^{200}$ A concurring opinion goes further, noting that

a finding of functionality offers a complete affirmative defense to a contributory infringement claim predicated solely on the reproduction of a functional attribute of the product. A functional characteristic is 'an important ingredient in the commercial success of the product,' and, after expiration of a patent, it is no more the property of the originator than the product itself. It makes no more sense to base contributory infringement upon the copying of functional colors than on the petitioners' decision to use the same formulation of the drug, or even to market the generic substitute in the first place. To be sure, the very existence of generic drugs 'facilitates' illegal substitution. But Ives no longer has a patent for cyclandelate, 'and the defendants have a right to reproduce it as nearly as they can.' Reproduction of a functional attribute is legitimate competitive activity. ${ }^{201}$

Trademark and unfair competition regimes play a variety of roles in controlling and regulating information technology network markets by

196. See Inwood Labs., 456 U.S. at 847.

197. See id.

198. See id. at 854-55 (recognizing that "pharmacists who mislabeled generic drugs with Ives' registered trademark violated [Lanham Act] $\mathbb{3} 32$ ”).

199. See id.

200. Id. at 850 n.10.

201. Id. at 862-63 (White, J., concurring) (citations omitted). 
enabling platform sponsors to regulate the usage of terms and symbols that signal interoperability and compatibility with particular standards and interfaces. ${ }^{202}$

Platform sponsors and standard setting organizations routinely establish certification and collective markets and use trademark law to police use of these designations. As noted above, Sun Microsystems (and now Oracle Corporation) uses the Java TCK test as well as certification marks to ensure that products using the Java trademark meet WORA interoperability standards. In the mid to late 1990s, Sun used the "100\% Pure Java" initiative to establish Java as a de facto industry standard. ${ }^{203}$ Sun successfully sued Microsoft for violating its agreement not to adhere to Java's standardized application environment and compliance tests so as to ensure interoperability. ${ }^{204}$

Platform sponsors have used trademark and false advertising law to combat confusing product names or packaging and police compatibility and interoperability claims. Apple Computer, for example, successfully prevented a competitor from using the term "Pineapple" for its clone device. ${ }^{205}$ As another example, Hewlett-Packard blocked an ink refiller from using confusingly similar packaging for replacement cartridges. ${ }^{206}$

In an interesting application of trademark's genericide doctrine, Intel Corporation sought to protect the " $\mathrm{x} 86$ " suffix from confusing use by a competitor. The court determined, however, that the "x86" designation had become generic among buyers and sellers of microprocessor chips. ${ }^{207}$ Consequently, Intel designated its fifth generation design the Pentium. By contrast, notwithstanding the serious questions a court raised about whether "Windows" was generic for a graphical user interface, ${ }^{208}$ Microsoft obtained federal registration for the Windows term. Google has successfully fended off claims that "google" has become a generic term for Internet search. ${ }^{209}$

202. See Mark A. Lemley, Peter S. Menell, Robert P. Merges, Pamela Samuelson \& BRIAN W. CARVER, 1 SOFTWARE AND INTERNET LAW ch. 4 (4th ed. 2011).

203. Paul Floren, Sun's Java: Can It Burn Microsoft?, N.Y. Times (Jan. 20, 1997), http://www.nytimes.com/1997/01/20/business/worldbusiness/20iht-java.t.html [https://perma.cc/Y3UQ-N2TW].

204. See Sun Microsystems, Inc. v. Microsoft Corp., 87 F. Supp. 2 d 992 (N.D. Cal. 2000).

205. See Apple Comput., Inc. v. Formula Int'l, Inc., 562 F. Supp. 775 (C.D. Cal. 1983).

206. See Hewlett-Packard Co. v. Nu-Kote Int'l, Inc., No. Civ.A.C94-20647JW (EA, 2000 WL 33992123 (N.D. Cal. 2000).

207. See Intel Corp. v. Advanced Micro Devices, Inc., 756 F. Supp. 1292 (N.D. Cal. 1991).

208. See Microsoft Corp. v. Lindows.com, Inc., No. C01-2115C, 2002 WL 32085606 (W.D. Wash. 2002).

209. See Elliott v. Google, Inc., 860 F.3d 1151 (9th Cir. 2017). 
Platform sponsors and complementary product manufacturers have used trademark and false advertising law to police use of compatibility and interoperability claims. In Princeton Graphics Operating, L.P. v. NEC Home Electronics (U.S.A.), Inc., ${ }^{210}$ the court applied a restrictive definition of compatibility because of the importance of precise definitions in the computer industry. ${ }^{211}$

In another interesting application of trademark law's functionality doctrine, the Ninth Circuit declined to allow Sega to use trademark law to prevent Accolade from selling interoperable products that displayed Sega's trademark as part of its lock-out code. ${ }^{212}$ The basis for the trademark claim was that the initialization code prompted a visual display for approximately three seconds that read "PRODUCED BY OR UNDER LICENSE FROM SEGA ENTERPRISES LTD." 213 The court rejected the false labeling claim as inconsistent with the purposes of the Lanham Act. ${ }^{214}$ It also held that Sega could not use trademark law to prevent competitors from marketing interoperable devices if the software design required display of what might otherwise be confusing trademark information. ${ }^{215}$ The court ruled that Sega failed to prove the existence of a feasible alternative to using the lock-out code that produced the misleading label ${ }^{216}$ Furthermore, Accolade had placed text on its packaging materials disclaiming any association with Sega. ${ }^{217}$

\section{Patent PRotection}

Patents have long provided the potential for exclusive rights for network technologies. For example, Alexander Graham Bell, who edged out Elisha Gray in a patent race over the telephone, gained monopoly control over the quintessential network technology. ${ }^{218}$ As the Supreme Court noted in Dolbear v. Am. Bell Tel. Co., ${ }^{219}$ although an inventor's claim might practically preempt

210. 732 F. Supp. 1258 (S.D.N.Y. 1990).

211. See Creative Labs, Inc. v. Cyrix Corp., 42 U.S.P.Q.2d 1872 (N.D. Cal. 1997) (following the Princeton Graphics Operating restrictive definition of compatibility and finding that a product advertisement asserting compatibility with a competing product must support the same functions).

212. See Sega Enters., Ltd. v. Accolade, Inc., 977 F.2d 1510 (9th Cir. 1992).

213. See id. at 1515.

214. See id. at 1528-30.

215. See id. at 1530-32.

216. See id.

217. See id. at 1529, 1532 n.11.

218. See generally Robert V. Bruce, Bell: Alexander Graham Bell And the CONQUEST OF SOLITUDE (1990).

219. 126 U.S. 1,535 (1888). 
all use of a discovery for the duration of the patent, this fact will "show more clearly the great importance of his discovery, [] it will not invalidate [the preempting] patent." Patents tracing back to Guglielmo Marconi wireless communications technology played a central role in the development of the radio and television industries. ${ }^{220}$ Xerox controlled the photocopying industry for several decades in the mid-20th century. Intel built its microprocessor juggernaut on patents. Other network technology industries-from modems $^{221}$ to cell phones (Code Division Multiple Access (CDMA)) ${ }^{222}$ —were built on patent portfolios. Concern over patents affects many standard-setting processes. $^{223}$

The extent to which patents enable control of network technologies depends on a range of factors, including the extent to which the patent controls network features (patent scope), the effective duration of patent protection, licensing structures (including patent pools), ${ }^{224}$ and antitrust constraints.

The advent of computer software introduced several additional complicating factors. As courts limited copyright protection for network features of computer software and the Federal Circuit expanded patent eligibility for software-related inventions in the 1990s, the patent system emerged as a battleground for software-related network technologies. Patent law's higher protection threshold compared to other intellectual property modes seeks to ensure that trivial advances remain available to the public while potentially providing substantial advances robust protection, thereby motivating platform developers to take on the challenge of overcoming the excess inertia of entrenched, but obsolete, platforms. Patent law's disclosure requirements enable the public to learn from technological advances. Nonetheless, patent protection's twenty-year duration, although far shorter than copyright protection, might still be excessive for software technologies. ${ }^{225}$ The uncertain scope of patent protection also poses some concern. Patent remedies can be especially strong, although standard-setting processes have

220. See generally Hugh G.J. Aitken, The Continuous Wave: Technology And AMERICAN RADIO 1900-32 (1985).

221. See Neil Gandal, Nataly Gantman \& David Genesove, Intellectual Property and Standardization Committee Participation in the US Modem Industry, in 1 STANDARDS AND PUBLIC POLICY 208 (Shane Greenstein \& Victor Stango eds., 2007).

222. See generally Dave Mock, The Qualcomm Equation: How a Fledgling Telecom Company Forged a New Path to Big Profits and Market Dominance (2005).

223. See generally Contreras, supra note 26.

224. See Michael Mattioli, Empirical Studies of Patent Pools, in 2 RESEARCH HANDBOOK ON the Economics of Intellectual Property (Peter S. Menell \& David L. Schwartz eds., 2019); see also, Mattioli, supra note 13.

225. See Menell, supra note 23, at 1364-65. 
tempered their effects and promoted collaboration. Finally, design patent protection has recently added a new weapon to the network technology arsenal.

This Section examines patent protection for network technologies. It emphasizes the most salient and contested area: computer software. Section 1 traces the evolution of patent protection for software-related inventions. Section 2 examines the complicated scope of patent protection. Section 3 discusses patent licensing. Section 4 explores patent remedies. Section 5 examines design patents and their emergence in network markets.

\section{Patentability Requirements}

The Patent Act sets forth five patentability requirements: (1) patentable subject matter; (2) utility; (3) novelty; (4) nonobviousness; and (5) disclosure. ${ }^{226}$ Two of these requirements have been particularly pertinent to network industries: subject matter eligibility and nonobviousness.

a) Subject Matter Eligibility

As noted above, the patent system has long afforded protection for network and systems technologies, ranging from the telephone to wireless communication and xerography. These technologies fit comfortably within the traditional scope of patent protection. The patent system has, however, struggled to accommodate software-related inventions. As illustrated above, APIs and other software technologies are increasingly important in network industries.

Notwithstanding that the patent statute expressly authorizes patenting of processes and machines, ${ }^{227}$ the availability of patent protection for softwarerelated inventions has been in flux since the beginning of the computer age. The issue emerged in the 1960s as computer systems became more versatile, software languages developed, and computer programming emerged from the shadow of electrical engineering. The Patent Office struggled to fit software inventions within the traditional classification system and struggled to keep up with the tremendous volume of prior art being generated. In 1965, President Johnson appointed a commission to assess the overall efficacy of the patent system. ${ }^{228}$ In recommending that Congress exclude computer programs from patent eligibility, the Commission of government officials, leading scientists, and representatives of industry (including IBM), noted that "the creation of

226. 35 U.S.C. $\iint$ 101, 102, 103, 112 (2018); see MENELL ET AL., supra note 2, ch. 3.

227. See 35 U.S.C. $\$ 101$.

228. Executive Order No. 11,215, 30 Fed. Reg. 4661 (1965). 
programs has undergone substantial and satisfactory growth in the absence of patent protection" and that "copyright protection for programs is presently available." ${ }^{229}$ But as discussed above, copyright excluded protection for functional features of expressive works.

Congress did not act on this recommendation, and the eligibility of software-related inventions fell to the Patent Office and the courts. Although granting a smattering of software-related inventions in the mid to late 1960s, the Patent Office took a skeptical view of software eligibility. This in part reflected concerns that about the PTO's ability to examine this new and rapidly developing technological field.

The Supreme Court was soon brought into the fray. An inventor challenged the PTO's rejection of his claim to an algorithm that converted binary-coded decimal numerals into pure binary numerals on subject matter grounds. ${ }^{230}$ The Court held that "[p]henomena of nature, though just discovered, mental processes, and abstract intellectual concepts are not patentable, as they are the basic tools of scientific and technological work.",231 The court noted, however, it was not categorically excluding software-related inventions from patent eligibility. ${ }^{232}$ Yet six years later, the Court ruled that even newly discovered algorithms should be treated as in the prior art, rendering software claims ineligible unless they contained some other inventive concept. ${ }^{233}$ The Supreme Court reversed course in 1981, holding that software claims should be viewed as a whole and that the touchstone for patentability of a process embodying a mathematical formula was whether there was significant post-solution activity that is "transforming or reducing an article to a different state or thing." 234

Over the ensuing twenty-five years, the Court of Appeals for the Federal Circuit loosened patent eligibility limitations. Building on Diehr, the Federal Circuit chipped away at the post-solution activity necessary to bring softwarerelated claims within $\int 101 .^{235}$ In 1998, the Federal Circuit held that business methods were eligible for patent protection so long as they produced a "useful, concrete and tangible result." 236

229. U.S. COMm. ON THE Judiciary, RePORT OF THE PrESIDENT'S COMMISSION ON the Patent System, S. ReP. Doc. No. 90-5 (1967).

230. See Gottschalk v. Benson, 409 U.S. 63 (1972).

231. Id. at 67 .

232. Id.

233. See Parker v. Flook, 437 U.S. 584, 594 (1978).

234. Diamond v. Diehr, 450 U.S. 175, 183, 188-89, 191-92 (1981).

235. See In re Alappat, 33 F.3d 1526 (Fed. Cir. 1994) (holding that the display of data on a computer screen could suffice).

236. See State St. Bank \& Trust Co. v. Signature Fin. Grp., 149 F.3d 1368, 1373 (Fed. Cir. 1998) (quoting In re Alappat). 
In the aftermath of the Federal Circuit's State Street Bank decision, the PTO shifted its position from skepticism about expansive patent eligibility to openness and even enthusiasm. Patents for software and business methods flooded the PTO. Entrepreneurs and venture capitalists saw patenting as a valuable tool for developing (or at least claiming) Internet businesses. The late 1990s witnessed unprecedented growth of start-up businesses based on speculative initial public offerings secured, in part, on patent portfolios.

The bursting of the Internet (dot-com) stock bubble in 2000 produced a dramatic shakeout. Bankruptcies and, subsequently, the auctioning and trading of Internet-related patents, became widespread. Entities whose sole purpose was to assert these patents emerged. Patent holding companies and nonpracticing entities sought to monetize their Internet patents, often purchased at bankruptcy auctions. Lawsuits by patent assertion entities produced a tidal wave of patent validity challenges as well as calls by Silicon Valley companies, policymakers, and scholars for policy reform.

These concerns led the Federal Circuit to reinvigorate patent eligibility limitations. ${ }^{237}$ In an en banc ruling, the Federal Circuit synthesized the Supreme Court's Benson, Flook, and Diehr precedents into the "machine-ortransformation test": a claimed process is patent-eligible under $\int 101$ if it is tied to a particular machine or if it transforms a particular article into a different state or thing. ${ }^{238}$ Applying this test, the Federal Circuit affirmed the Patent Office's rejection of a claim for a method for managing the consumption risk costs of a commodity. The Supreme Court upheld the Federal Circuit's decision, although it characterized the machine-or-transformation test as a "useful and important clue, an investigative tool, for determining whether some claimed inventions are processes under $\int 101$," but too rigid a test of the Patent Act's broad statutory definition of "process." 239 The Court declined to rule that business methods are categorically ineligible for patent protection. ${ }^{240}$

Two years later, the Supreme Court revived the Flook decision's rule that for a claim embodying a natural discovery or algorithm to be eligible for patentability, it must contain a sufficiently inventive concept beyond the

237. See, e.g., In re Nuijten, 500 F.3d 1346 (Fed. Cir. 2007) (holding that a watermarked electromagnetic signal does not fall into any of the four categories of patent-eligible subject matter); In re Comiskey, 554 F.3d 967 (Fed. Cir. 2009) (affirming rejection of a business method patent under $\int 101$ as merely relying on mental steps).

238. In re Bilski, 545 F.3d 943, 961 (Fed. Cir. 2008) (en banc).

239. Bilski v. Kappos, 561 U.S. 593, 604 (2010); 35 U.S.C. \ 100(b) (2018).

240. See Peter S. Menell, Forty Years of Wandering in the Wilderness and No Closer to the Promised Land: Bilski's Superficial Textualism and the Missed Opportunity to Return Patent Law to Its Technology Mooring, 63 STAN. L. REV. 1289, 1299-304 (2011). 
natural law or algorithm, even where the patentee discovered the natural law or algorithm. ${ }^{241}$ These decisions have dramatically shifted the patent-eligibility landscape, resulting in the invalidation of a vast swath of software-related claims and eliminating patent protection for pure business methods. The decisions have also reduced the availability of patent protection for softwarebased network technologies.

b) Nonobviousness

To ensure that patents are not granted to routine or conventional applications of known principles, the Patent Act stipulates that a patent for an invention may not be obtained if "the differences between the claimed invention and the prior art are such that the claimed invention as a whole would have been obvious before the [invention was made] to a person having ordinary skill in the art to which the claimed invention pertains." 242 This requirement has long been difficult to apply due to the difficulty of ignoring the fact of the claimed invention. To avoid such hindsight bias, the Federal Circuit interpreted $\int 103$ to require that the prior art teach, suggest, or motivate ordinary skilled artisans to combine prior art references to achieve the claimed invention. Absent such evidence, the claimed invention was nonobvious. ${ }^{243}$ While such suggestions can be relatively common in scientific publicationsthrough cross-references of other publications - they are not readily found in more commercial and applied fields, such as software engineering. Software products do not typically cross-reference other products. As a result, many seemingly obvious inventions from the standpoint of common knowledge were able to clear the Federal Circuit's nonobviousness test.

As software patent litigation exploded following the burst of the Internet bubble in 2000, the Federal Circuit's standard for determining whether an invention was sufficiently inventive came under scrutiny. In KSR International Co. v. Teleflex Inc., ${ }^{244}$ the Supreme Court tightened the nonobviousness standard by holding that the teaching-suggestion-motivation test was too rigid:

When there is a design need or market pressure to solve a problem and there are a finite number of identified, predictable solutions, a person of ordinary skill has good reason to pursue the known options within his or her technical grasp. If this leads to the

241. See Mayo Collaborative Servs. v. Prometheus Labs., Inc., 132 S. Ct. 1289 (2012); Alice Corp. v. CLS Bank International, 134 S. Ct. 2347 (2014).

242. 35 U.S.C. \103.

243. See, e.g., Teleflex, Inc. v. KSR Int'l Co., 119 Fed. App’x 282, 285 (Fed. Cir. 2005), rev'd, 550 U.S. 398 (2007); In re Dembiczak, 175 F.3d 994, 998 (Fed. Cir. 1999); In re Bergel, 292 F.2d 955, 956-57 (C.C.P.A. 1961) (predecessor court to the Federal Circuit).

244. 550 U.S. 398 (2007). 
anticipated success, it is likely the product not of innovation but of ordinary skill and common sense. In that instance the fact that a combination was obvious to try might show that it was obvious under $\ 103 .^{245}$

The KSR decision raised the patentability bar, especially for software-related technologies for which market factors and advances in collateral technologies are likely to drive new products and processes.

\section{Scope}

The extent to which patents control network technologies depends upon the scope of the patent claims. Pioneering patents can stake broad claims without fear of being anticipated by prior art, whereas incremental inventions in crowded technology fields only garner narrow protection. Moreover, pioneering inventors can often develop improvement patents that expand their control and duration of protection. Xerox successfully followed this strategy to monopolize the photocopying industry for several decades. ${ }^{246}$ The resulting "patent thicket" delayed entry into the plain paper copy industry.

Software patentees have used broad, vague functional claim language to obtain broad coverage for their inventions. ${ }^{247}$ By avoiding the statutory phrases "means" or "step" in their claims — which limit the scope of their claims to the particular embodiments in the specification and "equivalents thereof" 248 and instead using broad terms that lack structural limits such as "module," patent drafters have sought to control all software solutions to particular technological problems. ${ }^{249}$ Such claims have caused substantial problems in the Internet Age, and have resulted in a proliferation of demand letters, costly litigation, and nuisance value settlements.

The courts and the PTO have sought to rein in these problems. The Supreme Court invigorated the claim indefiniteness doctrine, enforcing the patent statute's requirement to "particularly point] out and distinctly claim[

245. Id. at 421.

246. See F. M. Scherer, Antitrust, Efficiency, and Progress, 62 N.Y.U. L. REV. 998, 1016-17 (1987); see generally Timothy F. Bresnahan, Post-Entry Competition in the Plain Paper Copier Market, 75 AM. ECON. REV. 15 (1985).

247. See Peter S. Menell \& Michael J. Meurer, Notice Failure and Notice Externalities, 5 J. LEGAL ANALYSIS 1, 33 (2013); FTC REPORT, supra note 38.

248. 35 U.S.C. $₫ 112(\mathrm{f})$.

249. See generally Mark A. Lemley, Software Patents and the Return of Functional Claiming, 2013 WIS. L. REV. 905 (2013). 
the subject matter" sought to be patented. ${ }^{250}$ The Federal Circuit has interpreted claim terms like "module" and other vague terms (which it refers to as "nonce" words) to invoke the limitations of $\int 112(\mathrm{f}) .{ }^{251}$ This interpretation limits claim scope to the embodiments in the specification and equivalents thereof. Further upstream, the Patent Office is pursuing administrative efforts to improve claim clarity. ${ }^{252}$

\section{Licensing}

Patent licensing plays a critical role in many network industries. Patents afford patent owners the power to prevent others from making, using, offering to sell, selling, or importing the patented invention in the United States during the term of the patent. ${ }^{253}$ They do not, however, ensure that patentees can practice their own patented invention. The owner of a patent that improves on patented technologies controlled by others would need a license from the upstream patent owner to make, use, or sell the improvement. Licensing provides the key.

Many network technologies employ patented technologies. Several distinctive licensing issues have developed to address network effects: (a) standard setting and commitments to license patents on FRAND terms; (b) insurance pools and license on transfer commitments; and (c) GPL viral license commitments. Overreaching licensing provisions can raise misuse and antitrust issues addressed in Part VI.

a) Standard-Setting and FRAND Commitments

SSOs seek to lessen the tension between employing the best technological solutions in industry standards and ensuring widespread access to standards by requiring members to disclose standard-essential patents (SEPs) and license them on FRAND terms. ${ }^{254}$ Most SSOs, however, have not expressly barred injunctive relief or set FRAND licensing schedules. In 2015, the Institute of Electrical and Electronics Engineers (IEEE) barred its members holding

250. Nautilus, Inc. v. Biosig Instruments, Inc., 134 S. Ct. 2120, 2124 (2014); 35 U.S.C. \112(b); Menell \& Meurer, supra note 247, at 33.

251. See Williamson v. Citrix Online LLC, 792 F.3d 1339, 1350 (Fed. Cir. 2015) (en banc).

252. United States General Accountability Office, Intellectual Property: Patent Office Should Define Quality, Reassess Incentives, and Improve Clarity, GAO-16-490 (July 20, 2016), https://www.gao.gov/assets/680/678113.pdf [https://perma.cc/LXV3-MDDG]; Peter S. Menell, It's Time to Make Vague Software Patents More Clear, Wired (Feb. 7, 2013), http://www.wired.com/opinion/2013/02/its-time-to-make-vague-software-patents-moreclear/ [https://perma.cc/94KB-ENTY].

253. See 35 U.S.C. $\$ 271$.

254. See Contreras, supra note 26, at 23; see also NAT'L RESEARCH COUNCIL OF THE NAT'L ACADS., supra note 36; Mattioli, supra note 13. 
patents covering IEEE standards from seeking or threatening to seek injunctions or exclusion orders against potential licensees who are willing to negotiate licenses. ${ }^{255}$

b) Insurance Pools and License on Transfer (LOT) Commitments

In response to widespread assertion of patents by non-practicing entities following the bursting of the Internet bubble in early 2000, several enterprises emerged to reduce patent risk. ${ }^{256}$ Since 2008, RPX (Rational Patent Exchange) Corporation has functioned as a consortium of technology companies that acquires patents that pose potential risks. RPX has promised not to assert patents in its portfolio. ${ }^{257}$

As a further pre-commitment strategy to prevent patent holdup, a growing number of technology companies have promised not to assert their patents under specified conditions. ${ }^{258}$ Google has led an initiative whereby companies agree to prevent their patents from ever being used by a non-practicing entity (NPE) against other member companies through a license on transfer (LOT) pledge. ${ }^{259}$ The LOT network produces a network benefit. As more companies join the pact, the freedom to be insulated from NPE patent assertion entities expands.

c) GPL 3.0

As noted earlier, patents did not play a substantial role in the software industry until the mid-1990s, after the GPL (1989) and the GPL 2 (1991) were established. Although neither version of the GPL expressly licensed patents, the Free Software Foundation took the position that the GPL 2 created an implied license. ${ }^{260}$

GPL 3.0 took aim at this issue. Section 10 provides that the licensee

255. IEEE-SA Standards Board Bylaws, Inst. OF ELECTRICAL AND ELECTRONICS ENGINEERS \6 (2015), http://standards.ieee.org/develop/policies/bylaws/approvedchanges.pdf [https://perma.cc/SEF8-PL2Y] (last visited Oct. 21, 2018).

256. See James M. Rice, The Defensive Patent Playbook, 30 Berkeley TECH. L.J. 725, 75253 (2015).

257. See RPX Corporation, WIKIPEDIA, https://en.wikipedia.org/wiki/RPX_Corporation [https://perma.cc/K6JK-EUVE].

258. See Rice, supra note 256, at 747-53.

259. Id. at 768-69; of. Jason Schultz \& Jennifer M. Urban, Protecting Open Innovation: The Defensive Patent License as a New Approach to Patent Threats, Transaction Costs, and Tactical Disarmament, 26 HARV. J.L. \& TECH. 1, 64-65 (2012) (proposing a precursor to the license on transfer model).

260. MEEKER, supra note 12 , at 127. 
may not impose any further restrictions on the exercise of the rights granted or affirmed under this License. For example, you may not impose a license fee, royalty, or other charge for exercise of rights granted under this License, and [the licensee] may not initiate litigation (including a cross-claim or counterclaim in a lawsuit) alleging that any patent claim is infringed by making, using, selling, offering for sale, or importing the Program or any portion of it. ${ }^{261}$

Section 11 goes further: each "contributor" to code governed by GPL 3.0 grants

a non-exclusive, worldwide, royalty-free patent license under the contributor's essential patent claims, to make, use, sell, offer for sale, import and otherwise run, modify and propagate the contents of its contributor version. ${ }^{262}$

That provision defines a contributor's "essential patent claims" to include

all patent claims owned or controlled by the contributor, whether already acquired or hereafter acquired, that would be infringed by some manner, permitted by this License, of making, using, or selling its contributor version. ${ }^{263}$

Section 11 does not extend to "claims that would be infringed only as a consequence of further modification of the contributor version."264

Section 11 further provides that a licensee who is aware of a patent license governing by GPL 3.0 code must make the corresponding source code to run the object code and modify the work publicly available or extend the patent license to downstream recipients. ${ }^{265}$ Alternatively, the licensee must deprive itself of the benefit of the license. Section 11 further includes a nondiscrimination provision ensuring that any patent licenses are extended to all recipients of the GPL 3.0 work and works based on it. ${ }^{266}$

These provisions pose several serious concerns to many commercial software developers. ${ }^{267}$ For example, many patent litigation settlements provide only limited, non-sublicenseable, and possibly royalty-bearing rights that would not comply with GPL 3.0 requirements. Thus, commercial enterprises have been reluctant to embrace GPL 3.0. As of February 2017,

261. GNU General Public License, supra note 151, at $\$ 10$.

262. Id. at $₫ 11$.

263. Id.

264. Id.

265. See id.

266. See id.

267. MEeKER, supra note 12, at 129-30. 
GPL 3.0 was the fourth most widely adopted open source license ( $8 \%$ of open source projects), behind the MIT License (a simple permissive) (31\%), GPL $2.0(18 \%)$, and Apache $2.0(15 \%){ }^{268}$

\section{Remedies}

Patent remedies play a critical role in the control of network technologies that are subject to patent assertions. The proliferation of software patents and litigation in the Internet Age generated tremendous exposure for network industry companies, leading to calls for statutory reform of patent remedies. ${ }^{269}$

a) Injunctive Relief

The patent right — the right to exclude others from practicing the patented technology — has historically been protected by injunctive relief. Courts traditionally viewed patent rights like other property interests and routinely protected them through a "property" rule-barring transgressors from trespassing or using the "property." 270 Thus, for most of the history of patent law, courts awarded a permanent injunction as the prospective infringement remedy absent extraordinary circumstances. ${ }^{271}$

The embrace of software and business method patents during the dot-com bubble of the mid- to late 1990s gave way to concerns about injunctions threatening major technology companies in the aftermath of the NASDAQ

268. Top Open Source Licenses, BLACK DUCK BY SYNOPSYS, https://www.blackduck software.com/top-open-source-licenses [https://perma.cc/3TR7-3T42] (last visited Apr. 7, 2019); Ayala Goldstein, Top 10 Open Source Licenses in 2018: Trends and Predictions, WHITE SOURCE (Dec. 3, 2018) https://resources.whitesourcesoftware.com/blog-whitesource/topopen-source-licenses-trends-and-predictions [https://perma.cc/29WN-FVYH] (noting that use of permissive open source licenses are on the rise; reporting that in 2018, 64\% of open source components have permissive licenses, an 8\% rise over 2017).

269. See FTC Report, supra note 38; see also Fed. Trade Comm’n, To Promote Innovation: The Proper Balance of Competition and Patent Law and Policy (2003).

270. See MercExchange, LLC v. eBay, Inc., 401 F.3d 1323, 1338 (Fed. Cir. 2005) ("Because the 'right to exclude recognized in a patent is but the essence of the concept of property,' the general rule is that a permanent injunction will issue once infringement and validity have been adjudged.’) (citing Richardson v. Suzuki Motor Co., 868 F.2d 1226, 1246-47 (Fed. Cir. 1989)), vacated and remanded, eBay Inc. v. MercExchange, L.L.C., 547 U.S. 388 (2006).

271. See id. (noting that "courts have in rare instances exercised their discretion to deny injunctive relief in order to protect the public interest") (citing Rite-Hite Corp. v. Kelley, Inc., 56 F.3d 1538, 1547 (Fed. Cir. 1995)); see also Roche Prods., Inc. v. Bolar Pharm. Co., 733 F.2d 858, 865-66 (Fed. Cir. 1984) ("[S]tandards of the public interest, not the requirements of private litigation, measure the propriety and need for injunctive relief."); Milwaukee v. Activated Sludge, Inc., 69 F.2d 577 (7th Cir.1934) (declining to issue an injunction where the shutdown of a sewage disposal plant posed public health danger). 
market crash in the early 2000s. Patents that had been acquired to attract venture capital were auctioned off in bankruptcy sales to patent monetization entities. ${ }^{272}$ The proliferation of demand letters and patent lawsuits led scholars, technology companies, policymakers, and jurists to reconsider the traditional view of patents as property interests that deserve near-automatic injunctive relief. ${ }^{273}$ The costs of identifying patent holders, negotiating among potentially hundreds of patent holders, and the disruption and delay of litigation created leverage for patent owners. The threat of injunctive relief and high monetary damages enabled holders of dubious patents to extract unwarranted and disproportionate value.

In a watershed decision, the Supreme Court ruled in eBay, Inc. $v$. MercExchange, $L L C^{274}$ that the award of injunctive relief in patent cases turns on equitable balancing of the traditional equitable factors associated with preliminary relief: (1) whether the harm is irreparable, (2) adequacy of monetary damages to compensate for the harm, (3) balance of hardships between the parties, and (4) the public interest. ${ }^{275}$ The eBay decision has changed patent remedies dramatically. Seaman finds that the overall rate of permanent injunctions being ordered as a remedy for patent infringement has dropped from near $100 \%$ to $72.5 \%{ }^{276}$ The drop is most significant in software cases $(53 \%)$. Patent assertion entities obtained permanent injunctions in just $16 \%$ of their victories.

Courts take SSO FRAND commitments into account in evaluating requests for injunctive relief under the eBay standard. Although many SSO policies do not expressly address whether SEP owners can seek injunctive

272. See Colleen V. Chien, From Arms Race to Marketplace: The Complex Patent Ecosystem and Its Implications for the Patent System, 62 HASTINGS L.J. 297, 304-06 (2010); KEVIN G. RIVETTE \& David Kline, Rembrandts in the Attic: Unlocking the Hidden Value of PATENTS (2000).

273. See William F. Lee \& A. Douglas Melamed, Breaking the Vicious Cycle of Patent Damages, 101 Cornell L. ReV. 399, 435-36 (2016); Peter S. Menell, The Property Rights Movement's Embrace of Intellectual Property: True Love or Doomed Relationship?, 34 ECOLOGY L.Q. 713, 718 (2007); Peter S. Menell, Governance of Intellectual Resources and Disintegration of Intellectual Property in the Digital Age, 26 BERKELEY TECH. L.J. 1523, 1549-50 (2011); see generally Lemley \& Shapiro, supra note 30.

274. See Mark P. Gergen, John M. Golden, \& Henry E. Smith, The Supreme Court's Accidental Revolution? The Test for Permanent Injunctions, 112 COLUM. L. REV. 203, 208-09 (2012). 275. 547 U.S. 388 (2006).

276. See Christopher B. Seaman, Permanent Injunctions in Patent Litigation After eBay: An Empirical Study, 101 IOWA L. REV. 1949, 1982-83 (2016). 
relief or exclusion orders, courts consider FRAND commitments in weighing the irreparable harm prong of the eBay equitable relief test. ${ }^{277}$

The eBay decision does not, however, leave the patent owner without a prospective remedy. The court will fashion a prospective monetary damage measure, such as a running royalty or a permanent damage amountessentially a compulsory license. ${ }^{278}$ The $e$ Bay decision has led to a rise in patent enforcement filings at the International Trade Commission, which enforces infringement findings with exclusion orders barring importation of infringing articles. $^{279}$

b) Monetary Relief

The Patent Act authorizes the award of "damages adequate to compensate for the infringement, but in no event less than a reasonable royalty for the use made of the invention by the infringer." 280 Thus, patentees can recover lost profits or a reasonable royalty resulting from infringing activity. The Patent Act further authorizes judges to increase damages awards up to three times the compensatory level where the infringer has acted willfully or recklessly. ${ }^{281}$ Policymakers and scholars see the goal of patent damages to restore the parties to the position they would have achieved had they negotiated a patent license before the infringement occurred. ${ }^{282}$

Patent law has long struggled to deal with apportioning patent value when a patent covers only one component of a larger product or system. ${ }^{283}$ The problem has become particularly acute in platform technologies involving multiple components and patented technologies. The serial nature of patent

277. Apple Inc. v. Motorola, Inc., 757 F.3d 1286, 1331-32 (Fed. Cir. 2014) (noting that absent unusual circumstances, such as an infringer refusing a FRAND royalty or unreasonably delaying negotiations, it will be difficult for a patent owner subject to a FRAND commitment to establish irreparable harm or that damages are not an adequate remedy, and that even when an infringer has refused to accept any license offer, that does not necessarily justify injunctive relief); cf. Apple Inc. v. Samsung Elecs. Co., 809 F.3d 633 (Fed. Cir. 2015) (emphasizing right to exclude and the importance of injunctions).

278. See Paice LLC v. Toyota Motor Corp., 504 F.3d 1293, 1314 (Fed. Cir. 2007); Christopher B. Seaman, Ongoing Royalties in Patent Cases After eBay: An Empirical Assessment and Proposed Framework, 23 TEx. InTELL. PROP. L.J. 203 (2015).

279. See Colleen V. Chien \& Mark A. Lemley, Patent Holdup, the ITC, and the Public Interest, 98 CORNELL L. REV. 1, 2-3 (2012).

280. 35 U.S.C. $\int 284$ (2018).

281. See id.; Halo Elecs., Inc. v. Pulse Elecs., Inc., 136 S. Ct. 1923 (2016).

282. See Lee \& Melamed, supra note 77 , at 392.

283. See Cincinnati Car Co. v. New York Rapid Transit Corp., 66 F.2d 592, 593 (2d Cir. 1933) (Learned Hand, J.) (observing that the allocation of profits among multiple components "is in its nature unanswerable"). 
litigation, the economic complexity of multi-component products, and courtimposed time limits on the presentation of evidence make it difficult for juries to apportion value among multiple components and factors driving market demand for infringing products. ${ }^{284}$

In theory, a wide range of royalty bases can be used with appropriately calibrated royalty rates to account for the myriad factors affecting consumer demand. In practice, however, the open-ended nature of the inquiry, ${ }^{285}$ can lead to a very large royalty range across comparable cases. The Federal Circuit has sought to rationalize awards by using the smallest saleable patentpracticing unit (SSPPU), as opposed to the entire market value of the product or system, as the royalty base. ${ }^{286}$

As noted above, SSOs have sought to alleviate the tension between technological progress and widespread access to standards by requiring members to disclose SEPs during the standard-setting process and license them to standards implementers on FRAND terms. ${ }^{287}$ Nonetheless, the valuation of SEPs is difficult, especially when industry standards encompass multiple technologies and hundreds of patents. The challenge lies in separating the value of the particular technologies and patents from the often tremendous value from standardization, which is attributable to network effects. Once consumers adopt a product, they become locked-in to the standard to varying degrees. This can provide patentees with tremendous leverage. Courts have surmounted this challenge by interpreting the principal goal of standard-setting agreements to be widespread adoption of the standard and barring FRAND licensors from capturing the coordination and network value of the standard. ${ }^{288}$

284. See Stuart Graham, Peter S. Menell, Carl Shapiro, \& Tim Simcoe, Final Report of the Berkeley Center for Law \& Technology Patent Damages Workshop, 25 Tex. InTELl. Prop. L.J. 115, 127-28 (2017).

285. See Georgia-Pacific Corp. v. U.S. Plywood Corp., 318 F. Supp. 1116 (S.D.N.Y. 1970) (identifying fifteen factors).

286. See LaserDynamics Inc. v. Quanta Comput., Inc., 694 F.3d 51 (Fed. Cir. 2012); Cornell Univ. v. Hewlett-Packard Co., 609 F. Supp. 2d 279 (N.D.N.Y. 2009) (Rader, J., sitting by designation); Uniloc USA, Inc. v. Microsoft Corp., 632 F.3d 1292, 1320 (Fed. Cir. 2011); Lucent Techs., Inc. v. Gateway, Inc., 580 F.3d 1301, 1336 (Fed. Cir. 2009); Ericsson, Inc. v. D-Link Sys., Inc., 773 F.3d 1201, 1226 (Fed. Cir. 2014) (citing VirnetX, Inc. v. Cisco Sys., Inc., 767 F.3d 1308 (Fed. Cir. 2014) (" $[\mathrm{W}]$ here multi-component products are involved, the governing rule is that the ultimate combination of royalty base and royalty rate must reflect the value attributable to the infringing features of the product, and no more.")).

287. See NAT’L RESEARCH COUNCIL Of THE NAT'L ACADS., supra note 36.

288. See Commonwealth Sci. \& Indus. Research Org. v. Cisco Sys., Inc., 809 F.3d 1295 (Fed. Cir. 2015); Ericsson, 773 F.3d at 1229-35; Microsoft Corp. v. Motorola, Inc., No. C10- 


\section{Design Patents}

Design patents, which afford fifteen years of protection for "new, original and ornamental designs for an article of manufacture," 289 have come into play in some network technology markets. As with copyright and trademark protection, design patents do not extend to the functionality of useful articles. ${ }^{290}$ Only utility patent protection can protect such elements.

Separating ornamental from functional features has proven difficult. The Federal Circuit will invalidate a design patent only if the claimed design is dictated solely by the function of the article of manufacture. ${ }^{291}$ Some decisions have applied a looser balancing test: asking whether a design is "primarily functional." ${ }^{292}$

The difficulty lies in the fact that functionality is often intertwined with ornamentality, especially in minimalist designs that merge form with function. Furthermore, compilations of design features can themselves be functional. Some Federal Circuit decisions address this challenge by dissecting the claimed design through a process that aligns with copyright law's treatment of the ideaexpression dichotomy. ${ }^{293}$ Thus, if a claimed design contains "both functional and ornamental features, the patentee must show that the perceived similarity is based on the ornamental features of the design." "294 The courts "factor】 out the functional aspects of [the claimed design] as part of its claim construction." 295 This approach, however, is in tension with the Federal

1823JLR, 2013 WL 2111217 (W.D. Wash. Apr. 25, 2013); In re Innovatio IP Ventures, LLC, No. 11 C 9308, 2013 WL 5593609 (N.D. Ill. Oct. 3, 2013).

289. 35 U.S.C. $\int 171$ (2018).

290. See Christopher Buccafusco \& Mark A. Lemley, Functionality Screens, 103 VA. L. REV. 1293, 1295 (2017); see Jason J. Du Mont \& Mark D. Janis, Functionality in Design Protection Systems, 19 J. INTELL. PROP. L. 261, 271 (2012).

291. See Best Lock Corp. v. Ilco Unican Corp., 94 F.3d 1563, 1566 (Fed. Cir. 1996).

292. L.A. Gear, Inc. v. Thom McAn Shoe Co., 988 F.2d 1117, 1123 (Fed. Cir. 1993)

[T] he utility of each of the various elements that comprise the design is not the relevant inquiry with respect to a design patent. In determining whether a design is primarily functional or primarily ornamental the claimed design is viewed in its entirety, for the ultimate question is not the functional or decorative aspect of each separate feature, but the overall appearance of the article, in determining whether the claimed design is dictated by the utilitarian purpose of the article.

Lee v. Dayton-Hudson Corp., 838 F.2d 1186, 1188 (Fed. Cir. 1988).

293. See supra Section V.B.2.a).

294. See OddzOn Prods., Inc. v. Just Toys, Inc., 122 F.3d 1396, 1405 (Fed. Cir. 1997).

295. See Richardson v. Stanley Works, Inc., 597 F.3d 1288, 1293 (Fed. Cir. 2010). 
Circuit's holding that claimed designs should be evaluated as a whole. ${ }^{296}$ Some decisions have suggested that courts can surmount the separability challenge by considering

whether the protected design represents the best design; whether alternative designs would adversely affect the utility of the specified article; whether there are any concomitant utility patents; whether the advertising touts particular features of the design as having specific utility; and whether there are any elements in the design or an overall appearance clearly not dictated by function. ${ }^{297}$

This standard parallels an earlier formulation of trademark law's functionality doctrine. ${ }^{298}$ This approach reflects a concern with design patents preempting competition. A design is functional if there are no alternative designs that accomplish a function equally well. ${ }^{299}$

The Federal Circuit applied these principles in a case involving interoperability. In Best Lock Corp. v. Ilco Unican Corp., ${ }^{300}$ Best Lock claimed an unusual profile for a key blade blank, the form used for manufacturing (cutting) keys. Ilco distributed key blanks with that key blade shape. The Federal Circuit found that function alone dictated the key blade design because "no alternative blank key blade would fit the corresponding lock."

The integration of form and function in many product markets has brought design patents into play in some network technology markets. Most notably, Apple successfully asserted design patents covering the rounded

296. See Egyptian Goddess, Inc. v. Swisa, Inc., 543 F.3d 665, 677 (Fed. Cir. 2008) (en banc) (rejecting focusing on a design's "point of novelty"); Crocs, Inc. v. Int'l Trade Comm'n, 598 F.3d 1294, 1302-03 (Fed. Cir. 2010).

297. PHG Techs., LLC v. St. John Cos., 469 F.3d 1361, 1366 (Fed. Cir. 2006); see Berry Sterling Corp. v. Pescor Plastics, Inc., 122 F.3d 1452, 1456 (Fed. Cir. 1997).

298. See In re Morton-Norwich Prods., Inc., 671 F.2d 1332, 1340-41 (C.C.P.A. 1982); see also Amini Innovation Corp. v. Anthony Cal., Inc., 439 F.3d 1365, 1371 (Fed. Cir. 2006) (stating that an "aspect" of a patented design is functional "if it is essential to the use or purpose of the article or if it affects the cost or quality of the article," which is a trademark functionality standard articulated in Inwood Labs., Inc., 456 U.S. at 850, n.10, discussed in supra Section V.C).

299. See, e.g., Rosco, Inc. v. Mirror Lite Co., 304 F.3d 1373, 1378 (Fed. Cir. 2002) (reasoning that "if other designs could produce the same or similar functional capabilities, the design of the article in question is likely ornamental, not functional"); Seiko Epson Corp. v. Nu-Kote Int'l, Inc., 190 F.3d 1360, 1368 (Fed. Cir. 1999) (explaining that "the design must not be governed solely by function, i.e., that this is not the only possible form of the article that could perform its function”); L.A. Gear, Inc. v. Thom McAn Shoe Co., 988 F.2d 1117, 1123 (Fed. Cir. 1993) ("When there are several ways to achieve the function of an article of manufacture, the design of the article is more likely to serve a primarily ornamental purpose.").

300. 94 F.3d 1563.

301. Id. at 1566 . 
rectangular shape of mobile communications devices against Samsung. ${ }^{302}$ Technology companies and designers have also obtained design patents on virtual designs, patents that cover the designs of graphical user interfaces for smartphones, tablets, and other products, as well as the designs of icons or other artifacts of various virtual environments. ${ }^{303}$

The strong monetary remedies available for design patents further encourage seeking design patents to protect features of network technologies. The Patent Act provides for recovery of the "total profit" on the sale of "any article of manufacture to which [a protected design] has been applied." 304 Although the Supreme Court held that the term "article of manufacture" encompasses both a product and a component of that product, ${ }^{305}$ the apportionment of damages in design patent cases is uncertain.

\section{INTERPLAY OF INTELLECTUAL PROPERTY PROTECTION AND COMPETITION POLICY IN NETWORK INDUSTRIES}

The Sherman Antitrust Act prohibits contracts in restraint of trade and monopolization or attempts to monopolize markets. ${ }^{306}$ The courts have long recognized that patent and copyright protections-government-authorized rights to exclude others from using protected technologies and copying works of authorship_function as limited exceptions to antitrust liability. ${ }^{307}$ Yet,

302. See Apple Inc. v. Samsung Elecs. Co., 786 F.3d 983 (Fed. Cir. 2015) (holding that iPhone and iPad designs were functional (and hence unprotectable under trademark law) but not functional under design patent law).

303. See Jason J. Du Mont \& Mark D. Janis, Virtual Designs, 17 StAn. TeCH. L. ReV. 107 (2013).

304. 35 U.S.C. $\int 289$ (2018).

305. See Samsung Elecs. v. Apple Inc., 137 S. Ct. 429 (2016).

306. See 15 U.S.C. $\iint 1-2$ (2018).

307. See FTC v. Actavis, 133 S. Ct. 2223, 2238 (2103) (Roberts, C.J., dissenting) (observing that a patent "provides an exception to antitrust law, and the scope of the patent-i.e., the rights conferred by the patent-forms the zone within which the patent holder may operate without facing antitrust liability"); Simpson v. Union Oil Co. 377 U.S. 13, 24 ("The patent laws which give a 17-year monopoly on 'making, using, or selling the invention' are in pari materia with the antitrust laws and modify them pro tanto.”); SCM Corp. v. Xerox Corp., 645 F.2d 1195, 1209 (2d Cir. 1981) (imposing antitrust liability for patentee's refusal to license on lawfully acquired patent "would severely trample upon the incentives provided by our patent laws and thus undermine the entire patent system"); Image Tech. Servs. v. Eastman Kodak Co., 125 F.3d 1195, 1217-18 (9th Cir. 1997) (recognizing that "[w]ithout bounds, claims based on unilateral [refusals to deal]" by patent and copyright holders "will proliferate" and "[t]he cost of such suits will reduce [their] incentive ... to risk the often enormous costs in terms of time, 
intellectual property rights can concentrate economic power in ways that undermine competition, leading courts and antitrust enforcement agencies to develop more nuanced and complementary views of the interplay between intellectual property protection and antitrust liability. ${ }^{308}$ This is especially true in network technology markets, where positive feedback effects often lead to strong and durable monopolies. At the same time, high concentration can promote desirable network effects.

These considerations ameliorate and complicate the interplay of intellectual property protection and competition policy. Section VI.A explores limitations on improper leveraging of intellectual property rights that arise in private enforcement of intellectual property and contracts. Section VI.B examines public enforcement of antitrust law and competition policy in network markets.

research and development' ') (quoting Kewanee Oil Co. v. Bicron Corp., 416 U.S. 470, 480 (1974)).

The patent and copyright misuse doctrines, however, serve as exceptions to the limited exception. See Motion Picture Patents Co. v. Universal Film Mfg. Co., 243 U.S. 502 (1917) (recognizing the patent misuse doctrine); Carbice Corp. of Am. v. Am. Patents Dev. Corp., 283 U.S. 27, supplemented, 283 U.S. 420 (1931) (holding that the patentee could not condition the right to use the patented invention on the purchase of unpatented materials, thereby establishing the staple article of commerce doctrine); Lasercomb Am., Inc. v. Reynolds, 911 F.2d 970 (4th Cir. 1990) (recognizing a copyright misuse doctrine).

308. See Atari Games Corp. v. Nintendo of Am., Inc., 897 F.2d 1572, 1576 (Fed. Cir. 1990) ("[T] he aims and objectives of patent and antitrust laws may seem, at first glance, wholly at odds. However, the two bodies of law are actually complementary, as both are aimed at encouraging innovation, industry, and competition."); Marina Lao, Unilateral Refusals to Sell or License Intellectual Property and the Antitrust Duty to Deal, 9 CORNELL J.L. \& PUB. POL'y 193, 193 (1999) ("Courts and academics alike considered intellectual property rights as exceptions to the antitrust law that must be narrowly construed.”); U.S. DEP’T OF JUSTICE \& FED. TRADE COMm'N, Antitrust Guidelines For the Licensing of Intellectual Property (1995), reprinted in 4 TRADE REG. REP. (CCH) 13,132

The intellectual property laws and the antitrust laws share the common purpose of promoting innovation and enhancing consumer welfare. The intellectual property laws provide incentives for innovation and its dissemination and commercialization by establishing enforceable property rights for the creators of new and useful products, more efficient processes, and original works of expression ... . The antitrust laws promote innovation and consumer welfare by prohibiting certain actions that may harm competition with respect to either existing ways or new ways of serving consumers.

Willard K. Tom \& Joshua A. Newberg, Antitrust and Intellectual Property: From Separate Spheres to Unified Field, 66 ANTITRUST L.J. 167 (1997). 


\section{A. PRIVATE ENFORCEMENT}

Courts have recognized limits on the exercise of patent and copyright protection that apply with special force in network industries. As we have already seen, various internal intellectual property doctrines-such as copyright's fair use doctrine and the use of equitable balancing in dispensing remedies-bring competition policy concerns into intellectual property law. In addition, courts have developed equitable and contract-based defenses to prevent anti-competitive abuses of intellectual property rights.

\section{Misuse Doctrines}

Drawing on tort law's "unclean hands" doctrine, courts developed the patent misuse doctrines as a common law equitable defense to an infringement claim. ${ }^{309}$ Unlike the purely equitable defense of "unclean hands," the misuse doctrines apply to suits for damages as well as equitable relief. The misuse doctrine bars patent owners from expanding the scope or term of the intellectual property right through licensing restrictions. The Supreme Court prevented Thomas Edison from leveraging a patent on motion picture projectors to control what films could be exhibited using that projector. ${ }^{310}$ The doctrine bars enforcement of the patent until the anti-competitive effects of the restriction have been purged.

The patent misuse doctrine applies whether or not an antitrust violation has been established. The expansion of the patent misuse doctrine in the 1940s led Congress to exclude contributory patent infringement claims from the ambit of patent misuse in the 1952 Patent Act. ${ }^{311}$ Nonetheless, the uncertain scope and severe remedy of patent misuse continued to generate criticism, especially as economists and courts came to question categorical antitrust prohibitions in favor of rule of reason balancing. ${ }^{312}$

309. See Christina Bohannan, IP Misuse as Foreclosure, 96 IowA L. REV. 475, 484-86, 515 (2011).

310. See Motion Picture Patents Co. v. Universal Film Mfg. Co., 243 U.S. 502 (1917) (refusing to enforce a licensing provision restricting use of the machine to motion pictures licensed by Edison's film company); see Carbice Corp., 283 U.S.; see also Morton Salt Co. v. G.S. Suppiger Co., 314 U.S. 488 (1942).

311. See 35 U.S.C. \271(d)(1)-(3) (2018).

312. See Herbert Hovenkamp, Antitrust and the Patent System: A Reexamination, 76 OHIO ST. L.J. 467, 485, 497 (2015); Bohannan, supra note 309, at 490-95; see generally Mark A. Lemley, The Economic Irrationality of the Patent Misuse Doctrine, 78 CALIF. L. REV. 1599 (1990); Herbert J. Hovenkamp, The Rule of Reason and the Scope of the Patent, 52 SAN DiEGO L. REV. 515 (2015) [hereinafter Hovenkamp, The Rule of Reason]; Robin C. Feldman, The Insufficiency of Antitrust Analysis for Patent Misuse, 55 Hastings L.J. 399, 422-23 (2003); see generally Robert P. Merges, 
Congress amended the Patent Act in 1988 to codify two additional patent misuse limitations. ${ }^{313}$ Congress insulated refusals to license any rights to a patent from charges of patent misuse. ${ }^{314}$ This provision, however, can effectively be side-stepped through contract, such as a FRAND commitment. In that circumstance, the third-party beneficiary of the SSO agreement has a breach of contract action for failure to license standard essential patents on FRAND terms ${ }^{315}$ Furthermore, Congress barred application of the patent misuse doctrine to tying arrangements unless the patentee has market power in the relevant market for the patent or has patented tying a product on which the license or sale is conditioned, ${ }^{316}$ thereby bringing patent misuse more closely in line with antitrust liability. ${ }^{317}$

The courts have struggled to disentangle patent misuse doctrine from antitrust analysis. ${ }^{318}$ Although the two fields share common concerns, the misuse doctrine has sought to promote intellectual property policies of encouraging innovation, freedom to operate outside of intellectual property protections, and access to the public domain even when objectionable practices do not violate antitrust law. ${ }^{319}$

In a case echoing the Motion Picture Patents case, a music copyright licensor sought to require theaters to obtain a performance license before they even knew what music would be incorporated into the films they would show. ${ }^{320}$ The district court found that such a license agreement improperly asserted control over all films and hence constituted copyright misuse. As a result, the court barred enforcement against the theater owner.

As the emergence of computer software brought copyright more directly into play in innovation markets, the copyright misuse doctrine has come into wider use. In Lasercomb America, Inc. v. Reynolds, ${ }^{321}$ a software copyright licensor

Reflections on Current Legislation Affecting Patent Misuse, 70 J. PAT. \& TRADEMARK OFF. SOC'Y 793, 793 (1988) (noting that "the often very limited (or 'thin') markets for patented technology make it difficult to apply antitrust law's consumer-demand definition of the relevant market").

313. Patent Misuse Reform Act of 1988, Pub. L. No. 100-703, 102 Stat. 4674 (1988).

314. See 35 U.S.C. $\$ 271(\mathrm{~d})(4)$.

315. See infra Section VI.A.4.

316. 35 U.S.C. $\int 271(d)(5)$.

317. See generally Hovenkamp, The Rule of Reason, supra note 312, at 515.

318. See Feldman, supra note 312; Bohannan, supra note 312, at 490-95; Janice M. Mueller, Patent Misuse Through the Capture of Industry Standards, 17 BERKELEY TECH. L.J. 623, 653-57 (2002); see generally Robert Pitofsky, Challenges of the New Economy: Issues at the Intersection of Antitrust and Intellectual Property, 68 ANTITRUST L.J. 913 (2001).

319. See Bohannan, supra note 309, at 505.

320. See M. Witmark \& Sons v. Jensen, 80 F. Supp. 843 (D. Minn. 1948), appeal dismissed, sub nom. M. Witmark \& Sons v. Berger Amusement Co., 177 F.2d 515 (8th Cir. 1949).

321. 911 F.2d 970 (4th Cir. 1990). 
prohibited licensees from "writing, developing, producing or selling computer assisted die making software, directly or indirectly without Lasercomb's prior written consent" for a term of ninety-nine years. Drawing on the principles underlying intellectual property protection as well as patent misuse jurisprudence, the court determined that copyright misuse is a valid defense and barred Lasercomb's infringement action. In this case, the licensor sought to foreclose competition in computer software innovation.

The copyright misuse doctrine has since been raised in a variety of settings, including tying arrangements, anticompetitive clauses in licensing agreements, mandatory blanket licenses, and refusals to license, but it remains murky. ${ }^{322}$ Several cases in which copyright misuse has been found to be viable involve network effects. For example, the Ninth Circuit held that the licensing terms of the American Medical Association's (AMA) Physician's Current Procedural Terminology to the Health Care Financing Administration gave the AMA a substantial and unfair advantage over its competitors and hence constituted copyright misuse. ${ }^{323}$ The Fifth Circuit in DSC Communications Corp. v. DGI Technologies, Inc. held that the copyright misuse doctrine might be viable to defend assertions of copyright protection over interoperable features of computer software. ${ }^{324}$ The Seventh Circuit in Assessment Technologies of WI, LLC v. WIREdata, Inc. held that licensing restrictions on a tax assessment database to control access to public domain data inputted by public tax assessors could constitute copyright misuse. ${ }^{325}$

As with the patent misuse doctrine, the interplay of copyright misuse doctrine and antitrust liability remains unclear. Courts applying the copyright misuse doctrine generally evaluate whether the conduct thwarts the underlying policies of copyright law. Some courts, however, mistakenly view the doctrine as co-extensive with antitrust law. ${ }^{326}$

\section{The Principle of Exhaustion}

With some resemblance to misuse, the long-standing common law doctrine of exhaustion (also known as first-sale) preserves the public interest in free competition by limiting the ability of IP owners to control secondary

322. See Jonas P. Herrell, The Copyright Misuse Doctrine's Role in Open and Closed Technology Platforms, 26 Berkeley TECH. L.J. 441, 466 (2011); see also Aaron Xavier Fellmeth, Copyright Misuse and the Limits of the Intellectual Property Monopoly, 6 J. InTELL. PrOP. L. 1, 24 (1998).

323. See Practice Mgmt. Info. Corp. v. Am. Med. Ass'n, 121 F.3d 516 (1995), amended by, 133 F.3d 1140 (9th Cir. 1997).

324. 81 F.3d 597 (5th Cir. 1996).

325. 350 F.3d 640, 647 (7th Cir. 2003).

326. See Fellmeth, supra note 322, at 22-23. 
markets for patented products and copyrights works. ${ }^{327}$ The idea is straightforward: the first authorized sale of the patented or copyrighted product exhausts the monopolistic power given to the owner as a reward for its efforts and contribution to society.

Following the first sale, the owner can no longer control the manner in which the product is sold or used in secondary markets, either by downstream purchasers or subsequent sellers. This limitation on monopoly, which traces back to the common law's general hostility towards restraints on alienation, fosters competition in secondary markets for innovative and creative works.

Recently, in a much-debated decision involving Lexmark cartridges, the Supreme Court emphasized the destructive anti-competitive effects post-sale restrictions that "run with" the product and exhibit servitude-like features have on free commerce. ${ }^{328}$ Refusing to allow patentees to "sputter" "the smooth flow of commerce," 329 the Court held that the principle of exhaustion prevents the enforcement of contractual post-sale restrictions through patent law. ${ }^{330}$ The patentee can impose contractual restrictions on secondary markets but cannot use patent law to control how the product is being used or sold downstream after the point of the first sale. The Lexmark decision reaffirmed the vital role that IP limiting doctrines such as preemption, exhaustion, and misuse play in limiting IP owners' ability to hinder downstream innovation thorough over-reaching, often boilerplate, contractual language. ${ }^{331}$

\section{Ambush of Standard-Setting Processes}

As highlighted in Section V.D.3, SSOs play a critical role in addressing the market failures surrounding network technologies. These organizations require companies that participate in standard setting processes to disclose relevant

327. See Adams v. Burke, 84 U.S. 453 (1873) (holding that once patented products have been sold, the patent holder may not restrict the way those products are used or sold in secondary markets); Bobbs-Merrill Co. v. Straus, 210 U.S. 339 (1908) (confirming the "first sale" doctrine in copyright law). Congress codified the exhaustion principle in the Copyright Act of 1976. 17 U.S.C. \109(a) (2018).

328. See Impression Prods. v. Lexmark Int'l, Inc., 137 S. Ct. 1523, 1530-32 (2017); Molly Shaffer Van Houweling, The New Servitudes, 96 GEO. L.J. 921 (2008) (describing the burden of servitude on free commerce); see also Molly Shaffer Van Houweling, Intellectual Property as Property, in 1 RESEARCH HANDBOOK ON THE ECONOMICS OF INTELLECTUAL PROPERTY (Ben Depoorter \& Peter S. Menell eds., 2019).

329. See Impression Prods., 137 S. Ct. at 1532.

330. See id. at 1531-33.

331. See Amit Elazari Bar-On, Unconscionability 2.0 and the IP Boilerplate: A Revised Doctrine of Unconscionability for the Information Age, 34 BERKELEY TECH. L.J. (forthcoming 2019); AARON Perzanowski \& Jason Schultz, The End of Ownership: Personal Property in the Digital ECONOMY chs. 9-10 (2016). 
information about actual and potential patents implicated by draft standards and commit to license such technologies on FRAND terms. ${ }^{332}$ Given the dynamic nature of technological progress, such conditions can be open to interpretation.

The two most prominent cases alleging that SSO participants engaged in deceptive practices-one involving Rambus and the other involving Qualcomm-reached different conclusions. The Rambus litigation grew out of standards development for dynamic random-access memory (DRAM) chips, a memory technology that was widely adopted throughout the computer industry. ${ }^{333}$ In 1990, Rambus sought patents on its architecture for such chips. Around that time, the Joint Electron Device Engineering Council (JEDEC) organized an open standard setting process with a broad range of industry participants including Rambus. As would be revealed in later litigation, Rambus used information gained at the meetings to amend its patent applications so that the standards would read on its patents. Rambus concealed these efforts and subsequently withdrew from JEDEC. After the JEDEC standards gained widespread acceptance in products, Rambus began making royalty demands from implementers and, beginning in 2000 , brought a series of enforcement actions. The jury in one of the key cases found that Rambus committed fraud and breached its JEDEC obligations by failing to disclose its patents. The Federal Circuit reversed in a divided opinion, with the majority finding that the JEDEC policy statements were too vague to support a fraud finding. ${ }^{334}$

The Qualcomm litigation grew out of the development of the Joint Video Team (JVT) standard for video compression technology. ${ }^{335}$ Qualcomm, a pioneer in semiconductor design for mobile communications devices and various other technologies, participated in the JVT standard setting process. It later sought to enforce several patents applicable to that standard against Broadcom. Broadcom successfully defended on the ground that Qualcomm had waived its rights to enforce the patent as a result of its failure to disclose the patents as part of the standard setting process. The court barred Qualcomm from enforcing the patents at issue against any products implementing the pertinent JVT standard.

332. See Mark R. Patterson, Leveraging Information About Patents: Settlements, Portfolios, and Holdups, 50 Hous. L. REV. 483, 513-21 (2012).

333. See Rambus Inc. v. Infineon Techs. AG, 318 F.3d 1081 (Fed. Cir. 2003).

334. See id. at 1098.

335. See Qualcomm Inc. v. Broadcom Corp., 548 F.3d 1004 (Fed. Cir. 2008). 
The different results in these litigations reflect several factors. SSO policies in the early 1990s varied in how clearly they set forth disclosure requirements. Furthermore, defendants in these cases faced a variety of complex evidentiary requirements and heightened pleading standards to equitable defenses such as laches, waiver, actual or implied license, equitable estoppel, and fraud. ${ }^{336}$ The Rambus controversy led to public enforcement actions in the United States and Europe that are discussed in Section VI.B.2.

\section{Breach of Contract for Failure to License SEPs on FRAND Terms}

As explored earlier, ${ }^{337}$ SSOs typically require companies participating in standard setting processes to commit to license standard essential patents on FRAND terms. The litigation between Microsoft and Motorola established key principles regarding the determination of FRAND licensing terms and provided for the award of contract damages for breach of the FRAND commitment. Motorola participated in standard setting processes governed by the IEEE and the International Telecommunication Union (ITU) establishing Wi-Fi (802.11) and video compression (H.264) standards. ${ }^{338}$ As part of its participation in these processes, Motorola agreed to license its patents that are essential to those standards on reasonable and non-discriminatory (RAND) ${ }^{339}$ terms.

The controversy began in October 2010 when Microsoft filed actions in the ITC and the Western District of Washington alleging that Motorola was infringing several Microsoft smartphone patents. ${ }^{340}$ Those filings immediately led to settlement negotiations involving cross-licensing of patents between the two companies. Later that month, Motorola sent letters to Microsoft requesting royalties equal to $2.25 \%$ of Microsoft's sales revenues from Windows and Xbox products incorporating the standards. Microsoft declined and immediately filed suit in the Western District of Washington alleging that Motorola's offer breached its RAND commitment. Microsoft asserted that it was a third-party beneficiary of the SSO agreements. Thereupon Motorola filed patent-enforcement suits with the ITC, seeking an exclusion order against importing Microsoft's Xbox products into the United States, and with a German court, seeking an injunction against sales of Microsoft's H.264-

336. See Sean Royall, Amanda Tessar \& Adam Di Vincenzo, Deterring "Patent Ambush" in Standard Setting: Lessons from Rambus and Qualcomm, 23 ANTITRUST 34 (2009).

337. See supra Section V.D.3-4.

338. See Microsoft Corp. v. Motorola, Inc., No. C10-1823JLR., 2013 WL 2111217 (W.D. Wash. Apr. 25, 2013) at *5, *8, *21,*49,*53.

339. FRAND and RAND are used interchangeably in the technology industries. FRAND is the more common usage.

340. See Microsoft Corp., 2013 WL 2111217. 
compliant products. The German action threatened all of Microsoft's Windows and Xbox European sales because its distribution center was located in Germany. As a result, Microsoft immediately relocated its distribution center to the Netherlands at substantial cost.

Judge Robart adapted the Georgia-Pacific reasonable royalty framework to the FRAND context. ${ }^{341}$ In so doing, he set forth the following principles:

(1) A RAND royalty should be set at a level consistent with the SSOs' goal of promoting widespread adoption of their standards[;]

(2) A proper methodology should] recognize and seek to mitigate the risk of patent hold-up that RAND commitments are intended to avoid[;]

(3) [A] proper methodology for determining a RAND royalty should address the risk of royalty stacking by considering the aggregate royalties that would apply if other SEP holders made royalty demands of the implementer[;]

(4) At the same time, a RAND royalty should be set with the understanding that SSOs include technology intended to create valuable standards[, which requires that] the RAND commitment [] guarantee that holders of valuable intellectual property will receive reasonable royalties on that property[; and]

(5) From an economic perspective, a RAND commitment should be interpreted to limit a patent holder to a reasonable royalty on the economic value of its patented technology itself, apart from the value associated with incorporation of the patented technology into the standard. ${ }^{342}$

Applying these economic guideposts, Judge Robart concluded that the reasonable royalty should be approximately 1/100th of Motorola's 2.25\% license offer. Motorola's patents constituted less than 10\% of the Wi-Fi 802.11 pool and none was shown to be of special importance. ${ }^{343}$ Judge Robart noted that if each of ninety-two companies that owned SEPs for the 802.11 and H.264 standards demanded a royalty rate comparable to Motorola's offer, the sum of the royalties would exceed the selling price of the Xbox. ${ }^{344}$ In a later proceeding, a jury awarded Microsoft $\$ 14.52$ million (\$11.49 million for

341. See Microsoft Corp., 2013 WL 2111217.

342. Id. at *12; see generally William H. Page, Judging Monopolistic Pricing: F/RAND and Antitrust Injury, 22 TEX. INTELL. PROP. L.J. 181 (2014).

343. See Microsoft Corp., 2013 WL 2111217, at *101.

344. Id. at $* 52, * 72-73$. 
relocating its distribution center and $\$ 3.03$ million in attorneys' fees and litigation costs) for Motorola's breach of its contractual commitment to license its standard essential patents on RAND terms. ${ }^{345}$

The Ninth Circuit upheld these determinations, expressly recognizing the key role of RAND commitments in "mitigat[ing] the risk that a SEP holder will extract more than the fair value of its patented technology .... Under these agreements, a SEP holder cannot refuse a license to a manufacturer who commits to paying the RAND rate." ${ }^{\text {346 }}$

\section{Private Antitrust Liability}

Section 4 of the Clayton Antitrust Act of 1914 authorizes recovery of damages by "any person . . . injured in his business or property by reason of anything forbidden in the antitrust laws," including section 7 of the Sherman Act. ${ }^{347}$ Companies have used this private right of action to combat anticompetitive practices in network industries. Three issues are particularly relevant to network technology markets: (i) refusal to license patented technologies; (ii) patent thickets; and (iii) leveraging of monopoly power.

a) Refusals to License Patented Technologies and CopyrightProtected Works

As noted above, the Patent Act grants patentees the exclusive right to use patented technologies. Congress reinforced that power by expressly providing that a refusal to license a patent cannot be the basis for a patent misuse defense. The courts are divided over whether a refusal to license patented technology can constitute an antitrust violation. The so-called "essential facilities" doctrine, which holds that "an owner of a crucial input cannot deny access if a firm seeking access cannot practicably obtain the input elsewhere" 348 has lost favor among commentators ${ }^{349}$ and the courts. ${ }^{350}$ The courts focus on whether

345. See id., at $* 101$.

346. Microsoft Corp. v. Motorola, Inc., 795 F.3d 1024, 1031 (9th Cir. 2015) (affirming Judge Robart's decision).

347. 15 U.S.C. $\int 15$ (1914).

348. James R. Ratner, Should There Be an Essential Facility Doctrine?, 21 U.C. DAVIS L. REV. 327, 330 (1988); Otter Tail Power Co. v. United States, 410 U.S. 366, 371, 377 (1973) (holding that a single firm's refusal to deal with other firms that denied them access to a facility essential to engaging in business violates antitrust law).

349. See generally Phillip Areeda, Essential Facilities: An Epithet in Need of Limiting Principles, 58 ANTITRUST L.J. 841 (1989); see also Ratner, supra note 348.

350. See Eastman Kodak Co. v. Image Tech. Servs., Inc., 504 U.S. 451 (1992) (declining to apply essential facilities doctrine); Aspen Skiing Co. v. Aspen Highlands Skiing Corp., 472 U.S. 585 (1985) (same). 
the defendant has a legitimate business justification for its conduct. ${ }^{351}$ The key modern cases involve the control of service and replacement part aftermarkets.

In the late 1980s, a variety of companies that had entered the market to service Kodak photocopiers found themselves cut off from replacement parts. ${ }^{352}$ Kodak ended its practice of licensing and selling replacement parts to competing service companies and required that its original equipment manufacturers not sell parts to independent service operators. The independent service organizations brought suit, claiming that Kodak unlawfully tied the sale of service for Kodak machines with the sale of parts in violation of section 1 of the Sherman Act, and monopolized or attempted to monopolize the sale of service for Kodak machines in violation of section 2 of the Sherman Act. Kodak defended in part on its intellectual property rights.

While recognizing that patent and copyright owners have exclusive rights to their protected works, the Ninth Circuit nonetheless held that these laws only afford the intellectual property owner a rebuttable "presumptively valid business justification" for consumer harm. ${ }^{353}$ The court upheld a jury verdict finding Kodak liable for monopolizing or attempting to monopolize the service aftermarket for Kodak copiers. ${ }^{354}$

In an analogous case involving Xerox's refusal to sell patented parts and copyrighted manuals and to license copyrighted software, the Federal Circuit declined to follow the Ninth Circuit's analysis. ${ }^{355}$ The Federal Circuit limited its focus to whether Xerox's refusal to sell its patented parts exceeded the scope of the patent grant. Finding that it did not, "Xerox was under no obligation to sell or license its patented parts and did not violate the antitrust laws by refusing to do so." ${ }^{356}$ The court ruled that so long as a patent infringement suit would not have been objectively baseless, the patentee's motivations for asserting its statutory right to exclude are immaterial. Similarly, the Federal Circuit further held that so long as Xerox's copyrights were not "obtained by unlawful means or were used to gain monopoly power beyond" the statutory grant, then 'Xerox's refusal to sell or license its copyrighted

351. See, e.g., Jonathan B. Baker, Promoting Innovation Competition Through the Aspen/Kodak Rule, 7 GEO. MASON L. REV. 495, 503-08 (1999).

352. See Image Tech. Servs., Inc. v. Eastman Kodak Co., 125 F.3d 1195, 1200-01 (9th Cir. 1997).

353. See id. at 1218 (quoting Data General Corp. v. Grumman Sys. Support Corp., 436 F.3d 1147, 1187 (1st Cir. 1994)).

354. See id. at 1228.

355. In re Indep. Serv. Org. Antitrust Litig., 203 F.3d 1322 (Fed. Cir. 2000); see Intergraph Corp. v. Intel Corp., 195 F.3d 1346 (Fed. Cir. 1999).

356. Indep. Serv. Org., 203 F.3d at 1328. 
works was squarely within the rights granted by Congress to the copyright holder and did not constitute a violation of the antitrust laws." 357

b) Patent Thickets

In a related vein, competitors have sought to challenge the accumulation of a broad portfolio of patents on antitrust grounds. Accumulation and pooling of patents can broaden the effective scope and reduce the uncertainty surrounding inventions, thereby enhancing appropriability. ${ }^{358}$ Nonetheless, strong and broad patent portfolios can discourage innovation and entry by potential competitors. ${ }^{359}$

The leading case involved Xerox Corporation, which built a portfolio of over 1,000 patents relating to its plain paper copying technology. Xerox only used 35 to 40 percent of those patents in actual Xerox products, ${ }^{360}$ relying on the balance to erect a defensive thicket around its photocopier technology. ${ }^{361}$ Xerox refused to grant licenses for plain paper copying, although it did grant some licenses for other fields, including coated paper copiers. SCM Corporation, which had licensed some of Xerox's patents for coated paper copies, filed an antitrust claim against Xerox alleging that "Xerox's acquisition of its patents and subsequent exercise of the exclusionary power in them violated the antitrust laws and injured SCM." ${ }^{362}$ SCM asserted that Xerox's patent accumulation strategy was intended to forestall competition, as reflected in its failure to use many of its patents. ${ }^{363}$ It further argued that "Xerox's acquisition of its patents and subsequent exercise of the exclusionary power in them violated the antitrust laws and injured SCM." "364 The Second Circuit acknowledged that "tension between the objectives of preserving economic

357. Id. at 1329.

358. See Gideon Parchomovsky \& R. Polk Wagner, Patent Portfolios, 54 U. PA. L. REV. 1, 32-41 (2005).

359. See generally Bronwyn H. Hall, Christian Helmers \& Georg von Graevenitz, Technology Entry in the Presence of Patent Thickets (Inst. for Fiscal Studies, Working Paper No. 16-02, 2016); Herbert Hovenkamp, Antitrust and the Movement of Technology, 19 GEO. MASON L. REV. 1119, 1130 (2012) (discussing the costs of defending against many patents of ambiguous scope); Daniel L. Rubinfeld \& Robert Maness, The Strategic Use of Patents: Implications for Antitrust, in 1 Antitrust, PATENTS, AND Copyright: EU AND US PERSPECTIVES 85 (François Lévêque \& Howard A. Shelanski eds., 2005).

360. See Gerald Sobel, The Antitrust Interface with Patents and Innovation: Acquisition of Patents, Improvement Patents and Grant-Backs, Non-Use, Fraud on the Patent Office, Development of New Products and Joint Research, 53 ANTITRUST L.J. 681 (1984).

361. See Kurt M. Saunders, Patent Nonuse and the Role of Public Interest as a Deterrent to Technology Suppression, 15 HARV. J.L. \& TECH. 389, 393 (2002).

362. SCM Corp. v. Xerox Corp., 645 F.2d 1195, 1203 (2d Cir. 1981).

363. See id. at 1202-03.

364. Id. at 1203. 
incentives to enhance competition while at the same time trying to contain the power a successful competitor acquires is heightened tremendously when the patent laws come into play," emphasizing that the Xerox case "demonstrate[s that the acquisition of a patent can create the potential for tremendous market power." "365 Nonetheless, the court ultimately ruled that "where a patent has been lawfully acquired, subsequent conduct permissible under the patent laws cannot trigger any liability under the antitrust laws." 366

The anticompetitive concerns relating to patent thickets are exacerbated by the ambiguity of many software patent claims. ${ }^{367}$ Cross-licensing and patent pools can, however, alleviate concerns about patent thickets. ${ }^{368}$ Economists generally believe that the inclusion of complementary and potentially blocking patents in a patent pool promotes competition by reducing the transaction costs and promoting licensing. ${ }^{369}$

\section{c) Improper Leveraging of Market Power}

In the mid-1990s, Microsoft Corporation held a dominant position in the desktop software marketplace just as the Internet emerged as an economic platform. Sun Microsystems's Java programming language for websites was rapidly gaining salience as a technology for easily transforming static webpages into engaging, animated, interactive websites. After failing to develop its own web development package, Microsoft entered into a Technology License and Distribution Agreement (TLDA) with Sun that allowed Microsoft to use, modify, and adapt Java technology in developing MS Internet Explorer 4.0 and other software products. ${ }^{370}$ To safeguard Sun's WORA interoperability

365. Id. at 1205.

366. Id. at 1206.

367. See generally James Bessen, Patent Thickets: Strategic Patenting of Complex Technologies (Research on Innovation, Boston Univ. School of Law, Working Paper No. 0401, 2004).

368. See Jonathan M. Barnett, The Anti-Commons Revisited, 29 HARV. J.L. \& TECH. 127 (2015); Jonathan M. Barnett, From Patent Thickets to Patent Networks: The Legal Infrastructure of the Digital Economy, 55 Jurimetrics J. 1 (2014); Richard J. Gilbert, Antitrust for Patent Pools: A Century of Policy Evolution, 2004 STAN. TECH. L. REV. 3 (2004); Carl Shapiro, Navigating the Patent Thicket: Cross Licenses, Patent Pools, and Standard Setting, in 1 InNOVATION POL'Y \& ECON. 119 (2000); Robert P. Merges, Institutions for Intellectual Property Transactions: The Case of Patent Pools, in 1 Innovation Policy for the KnOwledge of Society (Rochelle Cooper Dreyfuss, Diane Leenheer Zimmerman \& Harry First eds., 2001).

369. See Shapiro, supra note 368, at 144.

370. See Sun Microsystems, Inc. v. Microsoft Corp., 21 F. Supp. 2d 1109, 1113-14 (N.D. Cal. 1998). 
principle, the TLDA required that Microsoft adhere to Java's standardized application environment and compliance tests. ${ }^{371}$

Microsoft's deployment of its own version of Java, compatible only with other Microsoft products in violation of the WORA principle, threatened Sun's Java development strategy. In October 1997, Sun sued Microsoft for breach of contract, trademark infringement, copyright infringement, false advertising, and unfair competition. ${ }^{372}$ In early 2002, Microsoft agreed to pay Sun twenty million dollars and was permanently prohibited from using "Java compatible" trademarks on its products. ${ }^{373}$ The following year, Sun brought an antitrust and patent infringement action against Microsoft resulting in an award of over one billion dollars. ${ }^{374}$

\section{B. Public ENFORCEMENT}

Federal and state antitrust authorities have long played substantial roles in policing network market competition. The U.S. Department of Justice's filing of an antitrust action against IBM in 1969 reshaped the competitive landscape of the computer hardware industry and paved the way for a vibrant software industry. ${ }^{375}$ At the time, IBM bundled software and services into the cost of leasing use of its hardware, limiting competitors' ability to charge for software development and products. ${ }^{376}$ Immediately following the filing of the enforcement action, IBM unbundled software and services from its hardware sales thereby opening up markets for software products. ${ }^{377}$ Although the

371. See id. at 1114.

372. See John Markoff, Sun Sues Microsoft on Use of Java System, N.Y. Times (Oct. 8, 1997), https://www.nytimes.com/1997/10/08/business/sun-sues-microsoft-on-use-of-javasystem.html [https://perma.cc/Q6VK-55R8].

373. See Stephen Shankland, Sun, Microsoft Settle Java Suit, CNET (Mar. 15, 2002), https://www.cnet.com/news/sun-microsoft-settle-java-suit/] [https://perma.cc/V5DY$\mathrm{KS} 3 \mathrm{~F}]$.

374. Scarlet Pruitt \& Paul Roberts, Update: Sun, Microsoft Settle Suit in Billion-Dollar Pact, Microsoft to Pay $\$ 700$ Million for Antitrust Issues, $\$ 900$ Million to Resolve Patent Dispute, INFOWORLD (Apr. 2, 2004), http://www.infoworld.com/article/2667124/operating-systems/update--sun-microsoft-settle-suit-in-billion-dollar-pact.html [https://perma.cc/M9LD-6ZTL]; Stephen Shankland, Sun Brings Antitrust Suit Against Microsoft, The Company Files a Private Antitrust Suit Against Microsoft Seeking Damages That Could Top $\$ 1$ Billion, CNET (July 20, 2002), https://www.cnet.com/news/sun-brings-antitrust-suit-against-microsoft-1/

[https://perma.cc/2RR4-VWKT].

375. See Steven W. Usselman, Unbundling IBM: Antitrust and the Incentives to Innovation in American Computing, in The Challenge of Remaining InNovative 249, 249-50 (Sally H.

Clarke, Naomi R. Lamoreaux \& Steven W. Usselman eds., 2009).

376. See Barack Richman \& Steven Usselman, Elhange on Tying; Vindicated by History, 49 Tulsa L. REV. 689, 696-706 (2014).

377. See generally Burton Grad, A Personal Recollection: IBM's Unbundling of Software and Services, 24 IEEE ANNALS Hist. COMPUTING 64 (2002). 
antitrust case dragged on for more than a decade and was ultimately dropped, IBM's unbundling decision in conjunction with the emergence of mini and microcomputers markets revolutionized the computer industry. Similarly, the U.S. Department of Justice's filing of antitrust litigation against AT\&T in 1974 led to the breakup of the largest corporation in the United States nearly a decade later and hastened the modern competitive and highly innovative telecommunications marketplace. ${ }^{378}$

Advances in the information, financial, and communications technologies have vastly increased the significance of network markets as well as the government's role in regulating these markets. As highlighted in Parts II and III, network technologies are prone to high concentration levels that can enhance consumer welfare through network effects. Therefore, antitrust authorities have had to shift their focus away from market concentration toward anticompetitive tactics such as leveraging market power into new markets and stifling innovation. This Section summarizes the major contours of this shift. Section 1 discusses the evolution of Department of Justice and Federal Trade Commission guidelines for intellectual property licensing. Section 2 discusses significant network market enforcement actions and the challenges of crafting remedies.

\section{Intellectual Property Licensing Guidelines}

Beginning in the 1930's, antitrust regulators took a skeptical view of intellectual property. ${ }^{379}$ By the early 1970's, these concerns reached their apex in the U.S. Department of Justice Antitrust Division's "Nine No-No's":

(1) It is unlawful to require a licensee to purchase unpatented materials from the licensor;

(2) It is unlawful for a patentee to require a licensee to assign to the patentee any patent which may be issued to the licensee after the licensing arrangement is executed;

(3) It is unlawful to attempt to restrict a purchaser of a patented product in the resale of that product;

(4) A patentee may not restrict his licensee's freedom to deal in the products or services not within the scope of the patent;

378. See Breakup of the Bell System, WIKIPEDIA, https://en.wikipedia.org/wiki/ Breakup_of_the_Bell_System [https://perma.cc/MS4W-PV4Q].

379. See John DeQ. Briggs, Intellectual Property and Antitrust: Two Scorpions in a Bottle, 10 SEDONA CONF. J. 65, 67-68 (2009). 
(5) It is unlawful for a patentee to agree with his licensee that he will not, without the licensee's consent, grant further licenses to any other person;

(6) Mandatory package licensing is an unlawful extension of the patent grant;

(7) It is unlawful for a patentee to insist, as a condition of the license, that his licensee pay royalties in an amount not reasonably related to the licensee's sales of products covered by the patent-for example, royalties on the total sales of products of the general type covered by the licensed patent;

(8) It is unlawful for the owner of a process patent to attempt to place restrictions on his licensee's sales of products made by the use of the patented process; and

(9) It is unlawful for a patentee to require a licensee to adhere to any specified or minimum price with respect to the licensee's sale of the licensed products. ${ }^{380}$

Furthermore, even if a patent-related restraint was not per se unlawful under one of the Nine No-No's, the Department of Justice would still consider bringing an enforcement action if the particular provision was not necessary to the patentee's exploitation of its lawful monopoly and there were less restrictive alternatives to the restrictions that were more likely to foster competition. ${ }^{381}$ These enforcement principles focused on attempts by patent holders to extend their patent monopolies to unpatented supplies, to gain control over improvements of their innovations, to determine prices for resale of their patented products, or to engage in market allocations.

With the growing importance of intellectual property assets in the 1970s and 1980s and the dawning of the digital age, economists came to see unconstrained patent licensing as an innovation driver. ${ }^{382}$ In 1988, the Antitrust Division shifted from absolute (per se) opposition to licensing restrictions to a "rule of reason" approach to patent licensing that balanced the pro-competitive effects of licensing against potential anticompetitive

380. See generally Bruce B. Wilson, Special Assistant to the Assistant Attorney Gen., Antitrust Division Dep't of Justice, Remarks before the Fourth New England Antitrust Conference: Patent and Know-How License Agreements: Field of Use, Territorial, Price and Quantity Restrictions (Nov. 6, 1970).

381. See Briggs, supra note 379, at 65-93; see also Wilson, supra note 380.

382. See Richard Gilbert \& Carl Shapiro, Antitrust Issues in the Licensing of Intellectual Property: The Nine No-No's Meet the Nineties, Brookings Papers: Microeconomics 283, 286 (1997). 
effects in related markets. ${ }^{383}$ In 1995, the Department of Justice and the Federal Trade Commission (FTC) expanded upon the 1988 guidelines in crafting the "Antitrust Guidelines for the Licensing of Intellectual Property." 384 These guidelines expressly recognized the generally procompetitive nature of licensing arrangements, rejected the presumption that intellectual property necessarily creates market power in the antitrust context, and endorsed applying the same general antitrust approach to the analysis of conduct involving intellectual property that the agencies apply to conduct involving other forms of tangible or intangible property. ${ }^{385}$

With the growing role of patents in network industries, the Department of Justice and FTC increasingly recognized the importance of licensing SEPs on fair, reasonable, and non-discriminatory terms. ${ }^{386}$ Accordingly, the Department of Justice and the FTC have been far more receptive to patent pools. ${ }^{387}$ As Gilbert explains:

Competition policy toward patent pools has focused on the prevention of anticompetitive practices by patent pool membersindividually or collectively through the licensing policies of the pool-and has generally paid little attention to the question of how to encourage the formation and stability of patent pools that benefit consumers. While patent pools have substantial procompetitive benefits when the manufacture or use of products may infringe multiple patents, powerful economic forces prevent beneficial patent

383. U.S. DeP'T OF Justice, Antitrust EnForCEMENT Guidelines FOR INTERNATIONAL OPERATIONS (1988).

384. See U.S. Dep’t of Justice \& Fed. Trade Comm’n, Antitrust Enforcement GUIDELINES FOR INTERNATIONAL OPERATIONS (1995); see Letter from Thomas O. Barnett, Assistant Attorney Gen., U.S. Dep't of Justice Antitrust Division, to Michael A. Lindsay, Dorsey \& Whitney LLP (Apr. 30, 2007) (on file with the U.S. Dep't. of Justice) [hereinafter Letter from Thomas O. Barnett to Michael A. Lindsay].

385. See id.

386. See U.S. DeP't of Justice \& USPTO, Policy StATEMENT on REMEdies For Standards-ESSENTIAL PATENTS SubJECT TO VOLUnTARY F/RAND COMMITMENTS (2013); see generally Third Party Statement on the Public Interest, Inv. No. 337-TA-745 (June 6, 2012); FTC REPORT, supra note 38; Letter from Thomas O. Barnett to Michael A. Lindsay, supra note 384.

387. See, e.g., U.S. DeP’T Of Justice, Business REVIEW LeTTER RELATING TO VMEbus International Trade Association (2006); Letter from Thomas O. Barnett to Michael A. Lindsay, supra note 384; Letter relating to IEEE from Renata B. Hesse, Acting Assistant Attorney Gen., U.S. Dep't of Justice Antitrust Division, to Michael A. Lindsay, Dorsey \& Whitney LLP (Feb. 2, 2015); Negotiated Data Sols. LLC (N-Data), F.T.C. File No. 051-0094, 2008 WL 4407246 (Sept. 22, 2008); In re Motorola Mobility LLC, F.T.C. File No. C-4410 (2013). 
pools from forming or limit the patents in the pool to only a fraction of the patents that cover the products.

Competition policy should recognize the fragility of patent pools and ensure that patent pool members acting collectively have the same latitude to determine royalties and licensing terms as a single licensor, provided that the pool does not harm lawful competition that would have occurred in the absence of the pool's licenses. In determining which types of patents should be allowed in a pool, competition policy should recognize that a patent pool confers potential benefits if it includes two or more valid complementary patents, and need not harm competition if it has at least one valid patent that is essential to make, sell, or use a product. Inclusion of inessential patents raises potential concerns about foreclosure of alternative technologies and higher royalties for some licenses than would have occurred if these patents were excluded from the pool. However, these concerns should be balanced against the costs of excluding potentially essential patents from the pool. ${ }^{388}$

Disappointingly, the U.S. Dep't of Justice and FTC's updated intellectual property guidelines ${ }^{389}$ omit mention of SEPs and FRAND. ${ }^{390}$

\section{Significant Network Market Enforcement Actions}

Notwithstanding the Department of Justice's and FTC's loosening of licensing restrictions, antitrust authorities have pursued several notable enforcement actions in network industries over the past two decades.

In 1996, the FTC alleged that Dell Computer Corporation had violated the Federal Trade Commission Act by failing to disclose its patent rights during the Video Electronics Standards Association standard-setting process and then threatening to enforce those rights against others involved in that process. ${ }^{391}$ The resulting consent decree barred Dell from enforcing its patent against computer manufacturers incorporating the pertinent standard.

In 1998, the FTC issued a complaint against Intel Corporation alleging that Intel had sought to maintain its dominance in the microprocessor marketplace by denying essential technical information and product samples of new

388. Richard J. Gilbert, Ties that Bind: Policies to Promote (Good) Patent Pools, 77 ANTITRUST L.J. 1, 3-4 (2010).

389. See generally U.S. Dep'T of Justice \& Fed. Trade Comm'N, Antitrust Guidelines FOR THE LiCENSING OF INTELlECTUAL ProperTy (2017) (largely reaffirming and modestly updating the 1995 guidelines).

390. See Comments of Law and Business Scholars Submitted to the U.S. Department of Justice and Federal Trade Commission Regarding a Proposed Update to the Antitrust Guidelines for the Licensing of Intellectual Property (Sept. 25, 2016).

391. See Dell Computer Corp., 121 F.T.C. 616 (1996). 
microprocessors to companies that, because of intellectual property disputes, had initiated or threatened to initiate litigation against Intel or Intel's customers. ${ }^{392}$ The resulting consent decree recognized Intel's right to withhold licenses of its product or information, but limited Intel's ability to retract licenses when customers sought to vindicate its intellectual property rights.

Most significantly, the Department of Justice and eighteen states brought antitrust actions against Microsoft in 1998 alleging that Microsoft's bundling of its browser (Internet Explorer) with its Windows operating system along with restrictive licensing agreements with original equipment manufacturers (such as pricing use of its operating system based on a per processor basis). ${ }^{393}$ The government specifically targeted Microsoft's efforts to exclude Netscape from the browser market and to suppress Sun's Java web programming platform. The federal government settled its claims with Microsoft in 2001. ${ }^{394}$ The consent decree required Microsoft to share its application programming interfaces with third-party companies and established a process for supervising compliance with the agreement over a five-year period. Nine states proceeded to trial and ultimately implemented somewhat greater oversight over Microsoft's activities.

Crafting a remedy proved especially difficult due to the strong consumer benefits attributable to Microsoft's widely adopted and highly integrated computing platform. ${ }^{395}$ Breaking up the company would certainly have caused substantial consumer harm. In the end, the rapid emergence of the Internet Age and mobile computing-along with the ascendance of a new set of competitors such as Google and Facebook, as well as the resurgence of Apple_eroded Microsoft's dominance.

In 2012, the FTC required that Robert Bosch GmbH sell a SPX Service Solutions, a business that makes equipment used to recharge vehicle air conditioning systems, grant licenses to key patents needed to compete in the market for such equipment on the ground that SPX harmed competition by reneging on a commitment to license standard-essential patents on FRAND

392. See Intel Corp., No. 9288, 1999 F.T.C. LEXIS 145 (1999); see generally Pitofsky, supra note 318.

393. See United States v. Microsoft Corp., No. $98-1232$ (D.D.C. May 18, 1998); New York v. Microsoft Corp., No. 98-1233 (D.D.C. May 18, 1998).

394. See United States v. Microsoft Corp., WIKIPEDIA, https://en.wikipedia.org/ wiki/United_States_v._Microsoft_Corp.\#Settlement [https://perma.cc/4CUB-5FXP].

395. See United States v. Microsoft Corp., 253 F.3d 34, 102 (D.C. Cir. 2001) (reversing the district court order that would have broken Microsoft up because it failed to address Microsoft's contention that such an order would "lower [ rates of innovation and disrupt] the evolution of Windows as a software development platform”). 
terms. ${ }^{396}$ The FTC declared that "[p]atent holders that seek injunctive relief against willing licensees of their FRAND-encumbered SEPs should understand that in appropriate cases the Commission can and will challenge this conduct as an unfair method of competition under Section 5 of the FTC Act." 397 The Department of Justice has conditioned its approval of acquisitions of substantial patent portfolios by firms with substantial market presence on the commitments to license standard-essential patents on FRAND terms. Prominent examples include: (1) Google's acquisition of Motorola Mobility's portfolio of 17,000 patents and 6,800 patent applications; (2) Apple's acquisition of the nearly 900 patents originally held by Novell and purchased in 2010 by a coalition including Apple, EMC, Microsoft, and Oracle; and (3) acquisition by the "Rockstar" group (made up of Apple, Microsoft, and RIM) of the 6,000 patents and applications made available in the Nortel bankruptcy auction. ${ }^{398}$

\section{ASSESSMENT OF INTELLECTUAL PROPERTY PROTECTION AND COMPETITION POLICY FOR NETWORK TECHNOLOGIES}

Drawing on the evolution of intellectual property protection and competition policy explored in Parts V and VI, this Part assesses how the various legal, market, and policy institutions have adapted to the emergence of network technologies in the Information Age. Section VII.A discusses institutional and political economy considerations. Section VII.B then assesses the performance of legal and policy institutions based on the normative principles set forth in Part IV.

\section{A. Institutional CONSIDERATIONS}

Intellectual property is not a single, monolithic protective system but rather a complex, overlapping set of protections. Inventors and platform developers can utilize various modes of protecting their innovative endeavors. In addition, they can coordinate with other entrepreneurs to promote and leverage network effects, subject to antitrust constraints.

Protectionist entrepreneurs will naturally exploit the weakest link within the intellectual property chain to gain market advantage. As a result, the

396. See Press Release, Fed. Trade Comm'n, FTC Order Restores Competition in U.S. Market for Equipment Used to Recharge Vehicle Air Conditioning Systems (Nov. 26, 2012).

397. See id.

398. See Michael A. Carrier, What You Need to Know About Standard Essential Patents, 8 COMPETITION POL'y INT'L ANTITRUst CHRON. 6 (2014). 
efficacy of the intellectual property system depends critically upon intellectual property gatekeepers-judges, patent examiners, and antitrust enforcers-to ensure that the system coheres.

Therefore, the intellectual property system can be strained and fail to promote balanced protection where critical gatekeepers lack adequate understanding of the overall system or the technologies and economics at issue. The structure of the federal courts creates two opposing vulnerabilities. On the one hand, the regional circuit courts-which handle most copyright and trademark disputes_-lack specialization and technological training. They can struggle to understand the complexities of computer software and other technical subject matter in the network technology fields. On the other hand, the Federal Circuit-which handles all patent appeals and some copyright and trademark appeals_-is specialized, which can skew their perspective. As numerous scholars have explored, specialty courts, such as the Federal Circuit, are prone to tunnel vision and political capture which could lead to more protectionist interpretations of intellectual property law. ${ }^{399}$

As the Open Handset Alliance and the open source movement have demonstrated, free market institutions can check overbroad intellectual property protection. Entrepreneurs can contract around intellectual property systems in creative ways. ${ }^{400}$

\section{B. Measuring Progress Based on the Normative Principles}

The past half century, spanning the birth and ascendancy of the Information Age, has included dramatic evolution of intellectual property protection for network technologies. The process has not always been smooth, but has generally been inclined toward more efficient and effective rules and institutions. Nonetheless, the complexity of the intellectual property system

399. See, e.g., Rochelle C. Dreyfuss, The Federal Circuit: A Case Study in Specialized Courts, 64 N.Y.U. L. REV. 1, 26 (1989) (noting that specialized courts have improved patent law but have significant procedural defects); John R. Allison \& Mark A. Lemley, Empirical Evidence on the Validity of Litigated Patents, 26 AIPLA Q.J. 185, 241-42 (1998) (noting that specialized courts have improved patent law but have significant procedural defects); Robert P. Merges, One Hundred Years of Solicitude: Intellectual Property Law 1900-2000, 88 CALIF. L. REV. 2187, 2224, 2224-33, 2234-39 (2000) (noting that the federal circuit has been pro-patentee, especially in biotechnology, and that it has opened Congress to increased lobbying); WILLIAM M. LANDES \& Richard A. Posner, The Economic Structure of Intellectual Property LaW 334-53 (2003) (showing the court has been pro-patent in areas like upholding validity, and that this has resulted in an increase in patents); Richard A. Posner \& William M. Landes, An Empirical Analysis of the Patent Court, 71 U. CHI. L. REV. 111, 128 (2004) (showing the federal circuit is empirically as pro-patent as imagined).

400. See generally Merges, supra note 39 (2004) (providing examples of private IP contracting, such as PPIs and the Creative Commons license). 
and the dynamism of network technologies has produced persistent pathologies. Fortunately, the flexibility afforded by free market competition and new technologies (such as cloud-based computing) have been valuable antidotes and alternatives to unwarranted intellectual property protection and the accompanying market power. The evolutionary process continues to unfold, and adherence to the key normative principles will benefit from the lessons of the past and ongoing vigilance.

\section{Parsimony Principle}

The parsimony principle aims to promote realization of network benefits by denying intellectual property protection for functional attributes of network technologies absent significant technological advance. This principle comes into conflict with the motivation of some platform developers to control platform development and profit from network effects. Thus, leading platform technology companies advocate robust intellectual property protection for network features of computer software and other technologies through copyright, trademark, and design patent law. These legal regimes do not require assessment of novelty or nonobviousness. In an effort to garner long-lived copyright protection for interface and other software components, they have characterized software code as "high-tech poetry" and analogized computer programs to epic poems and great literature. ${ }^{401}$

Some general jurisdiction judges, with little technical background, were initially receptive to such arguments. They perceived the textual form of software code as more analogous to more conventional literary works than the gears and levers of machines and were less attuned to the broader intellectual property landscape channeling protection for functional features to the utility patent system. Dicta in Apple v. Franklin decision opined that "total compatibility with independently developed application programs ... is a commercial and competitive objective which does not enter into the somewhat metaphysical issue of whether particular ideas and expressions have merged." ${ }^{402}$ In Whelan Associates, Inc. v. Jaslow Dental Laboratory, Inc., ${ }^{403}$ the Third Circuit's conflation of merger analysis and the idea-expression dichotomy implicitly allowed copyright protection of procedures, processes, systems, and methods of operation that are expressly excluded under $\int 102(\mathrm{~b})$.

401. See Anthony L. Clapes, Patrick Lynch \& Mark R. Steinberg, Silicon Epics and Binary Bards: Determining the Proper Scope of Copyright Protection for Computer Programs, 34 UCLA L. REV. 1493, 1500 (1987); see also Anthony L. Clapes, Confessions of an Amicus Curiae: Technophobia, Law and Creativity in the Digital Arts, 19 U. DAYTON L. REV. 903, $903-04$ (1994).

402. Apple Comput., Inc. v. Franklin Comput. Corp., 714 F.2d 1240, 1253 (3d Cir. 1983).

403. 797 F.2d 1222 (3d Cir. 1986). 
Fortunately, a series of cases in the early to mid-1990s better appreciated the distinction between functionality and creative expression. ${ }^{404}$ As a result, while programming a computer can unquestionably be considered "creative" in a general sense, limiting doctrines ensure that the functional aspects are unprotectable under copyright law. The design of an efficient mechanical machine likewise can be creative, but such devices are not eligible for copyright protection unless the aesthetic features can be separated from the functional attributes under the useful article doctrine. ${ }^{405}$ Lines of code are the gears and levers of digital machines. The fact that computer software, like a sculptural work, is eligible for copyright protection does not authorize protection for functional features. ${ }^{406}$

Several major technological advances beginning in the mid-1990s deemphasized the role of copyright protection for computer software. The emergence of the Internet as a low-cost, highly scalable distribution ecosystem in the mid to late 1990s vastly expanded the potential for indirect appropriability (e.g., through keyword advertising) and shifted software developers toward open source development. Advances in mobile, Internetconnected digital devices in the early-2000 period paved the way for using software to promote sales of hardware and vastly expanded software distribution through app stores. The new app economy opened a vast array of non-copyright-based business models, such as new forms of advertising (e.g., Yelp). The emergence of cloud-based computing (Software as a Service) reinvigorated digital rights management. These shifts, in combination with the norms that took hold following the Lotus $v$. Borland litigation, produced a period of relative peace with regard to copyright protection of network features of computer software. ${ }^{407}$ The parsimony principle prevailed.

404. See Comput. Assocs. Int'l v. Altai, Inc., 982 F.2d 693, 695 (2d Cir. 1992); Sega Enters. Ltd. v. Accolade, Inc., 977 F.2d 1510, 1519 (9th Cir. 1993); Apple Comput., Inc. v. Microsoft Corp., 799 F. Supp. 1006, 1021 (N.D. Cal. 1992), aff'd in part, rev'd in part, 35 F.3d 1435, 144548 (9th Cir. 1994); Lotus Dev. Corp. v. Borland Int'l, Inc. 49 F.3d 807, 814-15 (1st Cir. 1995), aff'd by equally divided Court, 516 U.S. 233 (1996).

405. 17 U.S.C. $\int 101$ (2018) (definition of "[p]ictorial, graphic, and sculptural works" excludes functional features).

406. Id. \102(b).

407. See Brian Profitt, The Impact of Oracle's Defense of API Copyrights, ITWORLD (Aug. 23, 2011) http://www.itworld.com/article/2738675/mobile/the-impact-of-oracle-s-defense-ofapi-copyrights.html [https://perma.cc/B7QG-NT2P] (observing that "[h]istorically, APIs have been regarded as not falling under copyright - the reasoning being that APIs are not creative implementations but rather statements of fact," but also noting the issue had been clouded by the distinction of "open" and "closed"); see generally Menell, supra note 70, at 651. 
That peace was shattered in 2010 with Oracle's filing of a copyright (and patent) infringement lawsuit against Google alleging that the Android operating system infringed copyright protection for the declarations (function names and definitions) in the Java APIs. ${ }^{408}$ Drawing on the strategy of the first wave of API copyright litigation, Oracle analogized the labels and code used in the Java APIs to the chapter titles, character names, and plot elements of Harry Potter novels. ${ }^{409}$ Based on a questionable interpretation of Ninth Circuit precedent, ${ }^{410}$ the Federal Circuit ruled that the structure, sequence, and organization of the 37 Java APIs were copyrightable and remanded the fair use issue for retrial. ${ }^{411}$

Apple's garnering of design patent protection for the rounded, rectangle shape of its iPhone and iPod devices and visual icons also undercut the parsimony principle. ${ }^{412}$ These functional elements garnered substantial protection without any showing that they constituted novel and nonobvious technological advances.

These decisions directly undermine the parsimony principle. As a result of the Oracle v. Google decision, the safe harbor of clean-room implementation of functional specifications is no longer safe. The Oracle v. Google precedent creates the potential for software developers to assert long-lived copyright protection over interface specifications without meeting a substantial threshold of technological advance.

Thus, the Oracle v. Google decision warns innovators to steer clear of proprietary software in developing platforms and extensions. Future developers will be careful to avoid using APIs that are vulnerable to copyright assertion. This will reduce the flexibility to join or interoperate with platforms that are not open, but will encourage greater use of open platforms, collaboration, and ex-ante resolution of legal rights. Thus, even though the parsimony principle has been undermined, the flexibility to work around copyright protection through open source and collaborative solutions limits its adverse effects.

408. See Complaint for Patent and Copyright Infringement, Oracle Am., Inc. v. Google Inc., 872 F. Supp. 2d 974 (N.D. Cal. 2012) (No. C 10-03561 WHA), https://docs.justia.com/ cases/federal/district-courts/california/candce/3:2010cv03561/231846/1

[https://perma.cc/QV4W-6KST]; Menell, supra note 16, at 375-416.

409. See Opening Brief and Addendum for Plaintiff-Appellant at 12-13, Oracle Am., Inc. v. Google, Inc., 750 F.3d 1339 (Fed. Cir. 2014) (No. 17-1118).

410. See Menell, supra note 16, at 386-90.

411. Oracle Am., Inc., 750 F.3d 1339.

412. U.S. Design Patent Nos. D618,677, D593,087, and D604,305; see also Apple Inc. v. Samsung Elecs. Co., 786 F.3d 983 (Fed. Cir. 2015) (affirming lower court's decision that design patents were valid and had been infringed). 


\section{Proportionality Principle}

The proportionality principle is the flip side of the parsimony principle coin. Balanced protection for true technological advances in network technologies might be needed to overcome the excess inertia generated by network bandwagons. Patent law provides protection for novel, non-obvious, and adequately disclosed advances in computer systems, processes, and interface design, and other network technologies. Unlike copyright, trademark, or design patent law, utility patent protection protects the functional aspects for network technologies. In theory, therefore, patent protection can provide meaningful protection for overcoming excess inertia. Its efficacy, however, depends on whether it provides the right balance.

In practice, patent protection for interface design and other network technologies has been decidedly mixed. The standards for patent protection might be too low or too high and the duration of protection might be too short or too long to provide the optimal incentive. Moreover, unlike lock-out code, the scope of patent protection does not necessarily align with network features. Furthermore, the costs of pursuing and enforcing patents can distort incentives.

Patent protection of computer software, a principal source of network effects, has experienced a roller coaster over the past four decades. The PTO resisted patent protection for computer software until the late 1960s and only grudgingly afforded such protection in the 1970s and 1980s. ${ }^{413}$ The Supreme Court struggled to resolve the eligibility of patent protection for computer software in the $1970 \mathrm{~s},{ }^{414}$ but ultimately cautiously held that computer programs were eligible in $1981 .{ }^{415}$ Nonetheless, software companies were reluctant to pursue such protection, preferring technical protection measures and copyright protection. ${ }^{416}$

413. See Nelson Moskowitz, The Metamorphosis of Software-Related Invention Patentability, 3 COMPUTER/L.J. 273, 281-82, 309-11 (1982).

414. See, e.g., Gottschalk v. Benson, 409 U.S. 63 (1972); Parker v. Flook, 437 U.S. 584 (1978).

415. See Diamond v. Diehr, 450 U.S. 175 (1981).

416. See Menell, supra note 23, at 1346-47, 1351; MacGrady, Protection of Computer Software-An Update and Practical Synthesis, 20 Hous. L. REV. 1033, 1063-64 (1983); ROBERT Greene Sterne eT AL., The 2005 U.S. PATENT LANDSCAPE FOr EleCtronic Companies 3 (2005)

The 1980s saw an amazing business phenomena in the U.S. of creation of many start up electronic companies, some of which broke out of the pack of their competitors to become very large companies in their own right. Notable examples are Apple, Microsoft, Oracle, Cisco, Sun, [and] AOL. . . . 
Several factors shifted the software industry toward patent acquisition in the early 1990s. Fading hardware companies turned to patent licensing and enforcement campaigns. ${ }^{417}$ In addition, some smaller software companies succeeded in enforcing software patents against larger software companies. ${ }^{418}$ These developments prompted software companies to pursue defensive patenting. ${ }^{419}$ Furthermore, the Federal Circuit liberalized the standards for protecting computers software, ${ }^{420}$ just as the Internet (dot-com) era was taking off. This led to a software patenting gold rush in which start-up companies sought patents as signals for raising venture capital and established companies stockpiled patents for defensive purposes.

As discussed in Section V.D, the bursting of the dot-com bubble in 2000 resulted in many software patents falling into the hands of patent aggregators, such as Intellectual Ventures, which produced an unprecedented wave of costly and disruptive patent assertion activity. The low quality and amorphous scope of many of these patents imposed tremendous costs on the software industry and complicated entry into many network technology markets. In addition, new network technologies, such as smart phones, developed in a patent thicket ecosystem.

The effects of patent aggregation and assertion were somewhat alleviated by standard setting organizations requiring FRAND cross-licensing, the emergence of defensive buying funds, such as RPX and Allied Security Trust, and patent pledges. ${ }^{421}$ Moreover, the Supreme Court substantially reduced the

As upstarts, these companies in general did not embrace patents in the slightest.

cf. RivetTE \& KLINE, supra note 272, at 41-42 (suggesting ignorance of patent law and antipathy towards software patents as among the reasons companies did not pursue them).

417. See generally Marshall Phelps \& David Kline, Burning the Ships: INTELLECTUAL PROPERTY AND THE TRANSFORMATION OF MiCROSOFT (2009); see also ADAM B. JAFFE \& JOSH LERNER, INNOVATION AND ITS DisCONTENTS: HOW OUR BROKEN PATENT System Is ENDANGERING InNOVATION AND PROGRESS, AND WHAT TO DO ABOUT IT 14 15 (2004); RIVETTE \& KLINE, supra note 272, at 125.

418. See, e.g., Lawrence M. Fisher, Microsoft Loses Case on Patent, N.Y. Times (Feb. 24, 1994), https://www.nytimes.com/1994/02/24/business/microsoft-loses-case-on-patent.html [https://perma.cc/V76Y-EDA9]; Stac Elec. v. Microsoft Corp., No. 93-0413 (S.D. Cal. 1994), appeal dismissed per stipulation, 38 F.3d 1222 (Fed. Cir. 1994).

419. See FTC REPORT, supra note 38 (discussing defensive patenting).

420. See In re Alappat, 33 F.3d 1526 (Fed. Cir. 1994); State St. Bank \& Tr. Co. v. Signature Fin. Grp., 149 F.3d 1368 (Fed. Cir. 1998) (overruling the "business method" exception).

421. See generally Schultz \& Urban, supra note 259. 
risk of injunctive relief, ${ }^{422}$ tightened the nonobviousness standard, ${ }^{423}$ promoted clearer patent boundaries, ${ }^{424}$ and restricted patent eligibility. ${ }^{425}$ Congress passed legislation streamlining administrative patent review. ${ }^{426}$

Nonetheless, patent protection for network technologies has proven to be a complex and costly tool for achieving proportional appropriability for network technology innovations. The system has, however, become more balanced and predictable, with improved screening of patent applications, more timely and cost-effective means for invalidating dubious patents through inter partes review at the Patent Trial and Appeal Board, and improved coordination through standard setting and FRAND licensing.

\section{Deterrence Principle}

The deterrence principle stems from, and interacts with, the proportionality principle. Network effects often lead to high market concentration levels, which bring market power with them. The deterrence principle seeks to stunt abuse of such power while promoting network benefits. One of the main antidotes to market dominance by a single platform sponsor is collaboration through standard-setting organizations and licensing agreements, such as FRAND commitments. While such private solutions can promote innovation and downstream competition, they create the potential for anti-competitive behavior.

The past several decades have witnessed substantial evolution of antitrust doctrines and enforcement policies toward a balanced innovation and competitive ecosystem. Antitrust enforcers have come to appreciate the economic benefits of high concentration in network technology markets while also focusing on abusive practices, such as failure to disclose essential patents to standard setting organizations. Standard setting organizations have developed more sophisticated disclosure requirements. In addition, courts

422. See eBay, Inc. v. MercExchange, LLC, 547 U.S. 388 (2006) (holding that the Federal

Circuit's general rule that courts should issue permanent injunctions against patent infringers was invalid).

423. See KSR Int'l Co. v. Teleflex Inc., 550 U.S. 398 (2007) (holding that the Federal Circuit's "teaching, suggestion, or motivation" test for nonobviousness was too rigid).

424. See Nautilus, Inc. v. Biosig Instruments, Inc., 572 U.S. 898 (2014) (holding that the Federal Circuit's "amenable to construction" test was insufficiently precise).

425. See Bilski v. Kappos, 561 U.S. 593, 604 (2010) (holding that the "machine-ortransformation" test is not the sole test of patent eligibility); Mayo Collaborative Servs. v. Prometheus Labs., Inc., 566 U.S. 66, 82-85 (2012) (establishing a two-part test for patent subject matter eligibility); Alice Corp. Pty. Ltd. v. CLS Bank Int'l, 134 S. Ct. 2347, 2355 (2014) (refining Mayo's two-part test for patent subject matter eligibility).

426. American Invents Act, Pub. L. No. 112-29, 125 Stat. 284 (2011). 
have broadened their assessment of antitrust, contract, and patent remedies in view of network effects.

The dynamism of network technologies and markets, however, will continue to challenge enforcers, policymakers, and courts. As reflected in the Sun v. Microsoft and Oracle v. Google litigation, there is a subtle line between promoting interoperability and encouraging innovative forking of established standards. ${ }^{427}$

\section{FUTURE RESEARCH DIRECTIONS}

Following Moore's and Metcalfe's "Laws," network technologies are growing at exponential rates. Digital technologies increasingly drive economic growth. Due in substantial part to the Internet and advances in digital technology, network effects are rapidly diffusing across the economic landscape. Consequently, the interplay of network technologies and intellectual property will continue to evolve rapidly in the coming years and decades.

The opportunities for further research in this field are nearly limitless. Network effects are increasingly important across a growing swath of industries: consumer and industrial products (Internet of Things), energy (smartgrid, autonomous driving, renewable energy), bioinformatics, machine learning, social media, advertising, content creation, and science (database development). The interactions with the range of economic modes (such as contract, business associations, and multi-sided markets), as well as other areas of law (such as privacy and civil liberties) provide a wealth of important research opportunities to explore.

Perhaps most significantly, social media platforms, such as Facebook, Instagram, YouTube, and Twitter, are increasingly important not only to economic activity but also to social mobilization, electoral processes, and the functioning of democracy. These platforms are driven by network effects but are also notable for their polarizing tendencies. ${ }^{428}$ These broader ramifications of network effects are critical to legal, social science, and public policy research and reform.

427. Cf. Joseph Farrell, Compatibility and Competition Policy, in STANDARDS AND PUBLIC POLICY 372, (Shane Greenstein and Victor Stango eds., 2007).

428. See Cass R. Sunstein, \#Republic: Divided Democracy in the Age of Social Media (2017); Uri Y. Hacohen \& Peter S. Menell, Unjust Endorsement: How SOCIAL MEDia CORRupts COMMERCE AND DEMOCRACY AND WHAT TO DO ABOUT IT (this work is still in process at the time of publication). 